\title{
LEVANTAMENTO FLORÍSTICO DE PLANTAS AQUÁTICAS E PALUSTRES NA REPRESA GUARAPIRANGA, SÃO PAULO, BRASIL
}

\author{
MARIA ESTEFÂNIA FERNANDES RODRIGUES*, VINICIUS CASTRO SOUZA** \& \\ MARCELO LUIZ MARTINS POMPÊO***
}

\author{
*Departamento de Botânica, Instituto de Biociências, Universidade de São Paulo, \\ Rua do Matão 277, 05508-090 - São Paulo, SP, Brasil. \\ **Departamento de Ciências Biológicas, Escola Superior de Agricultura Luiz de Queiroz, \\ Universidade de São Paulo, 13418-900 - Piracicaba, SP, Brasil. \\ ${ }^{\star * *}$ Departamento de Ecologia, Instituto de Biociências, Universidade de São Paulo, \\ Caixa Postal 9, 13418-900, São Paulo, SP, Brasil
}

\begin{abstract}
Floristic composition of aquatic and palustris plants in the Guarapiranga Reservoir, São Paulo, Brazil). The aim of this study was to investigate the composition of aquatic and palustris plants in the Guarapiranga reservoir, and to contribute to the taxonomic knowledge of the species. Monthly fieldworks were performed from June/2008 to May/2009, in 20 stands of aquatic plants distributed throughout the reservoir. The species present were collected and registered in each stand. The aquatic macrophytes community of the reservoir is composed of 133 species belonging to 89 genera distributed in 45 families being 127 angiosperms, five ferns and one liverwort. The most representative families were Cyperaceae with 27 species, followed by Poaceae (14) and Asteraceae (10). Of the 67 species considered as weeds, only 14 are subspontaneous or naturalized, the other 120 species are native, six of which are endemic in Brazil. The present work contributed significantly to the flora of aquatic plants and palustris of São Paulo, as well as to List of Flora of Brazil, registering species that had not been previously recorded to the state of São Paulo, in this the work is besides a key of identification and descriptions of the species present in the study area. In conclusion, species richness of aquatic plants and palustris at Guarapiranga is high.
\end{abstract}

Key words: Aquatic plants, macrophytes, wetlands, hydrophytes.

\begin{abstract}
Resumo - (Levantamento florístico de plantas aquáticas e palustres na Represa Guarapiranga, São Paulo, Brasil) - O objetivo desse trabalho foi verificar a composição de plantas aquáticas e palustres no reservatório Guarapiranga, além de contribuir para o conhecimento taxonômico das espécies. Foram realizadas coletas mensais de julho/2008 a junho/2009, em 20 bancos de plantas aquáticas distribuídos ao longo de todo o reservatório. Em cada banco foram coletadas e registradas as espécies presentes. A comunidade de plantas aquáticas e palustres do reservatório é composta por 133 espécies, pertencentes a 89 gêneros, distribuídos em 45 famílias, sendo 127 de Angiospermas, 5 de Samambaias e 1 de Hepática. As famílias mais representativas foram Cyperaceae com 27 espécies, seguida de Poaceae (14) e Asteraceae (10). Das 67 espécies consideradas plantas daninhas ou infestantes, apenas 14 são subespontâneas ou naturalizadas, as demais 120 espécies são nativas, sendo 6 endêmicas do Brasil. O presente trabalho contribuiu significativamente para a Flora de plantas aquáticas e palustres, bem como para Lista da Flora do Brasil, registrando espécies que não haviam sido referidas anteriormente para o estado de São Paulo, além da apresentação de uma chave de identificação e descrições para as espécies presentes na área de estudo. Foi possível concluir que a Represa Guarapiranga possui uma elevada riqueza de plantas aquáticas e palustres
\end{abstract}

Palavras-chave: plantas aquáticas, macrófitas, alagados, hidrófitas.

\section{Introdução}

A identificação das espécies de plantas aquáticas em um corpo de água é uma etapa crítica em planos de manejo, por várias razões. Primeiro porque as diversas espécies frequentemente respondem de forma diferente às técnicas de controle. Segundo porque é importante determinar se alguma planta rara ou de importância fundamental no ecossistema está presente. E terceiro porque é crucial diagnosticar a presença de qualquer planta exótica ou alóctone (Schardt \& Ludlow 1993 apud Tanaka et al. 2002).

Apesar de ter inegável importância, o levantamento da ocorrência de plantas aquáticas ainda é um grande desafio, pois elas pertencem a grupos bastante distintos, ecologica e taxonomicamente, ocorrem em ampla variação de ambientes (de áreas de várzeas até profundidades superiores a 10 metros), apresentam espécies com morfologia muito diferentes, além de alterar a distribuição espacial de um ano para outro (Malthus \& George 1997, Jensen \& Davis 1987 apud Tanaka et al. 2002, Martins et al. 2003).

Amaral et al. (2008) também consideram a identificação de plantas aquáticas difícil, primeiro devido à grande plasticidade fenotípica que elas apresentam, sendo facilmente modificadas por condições do ambiente; outra dificuldade é que as plantas aquáticas são encontradas geralmente sem 
estruturas reprodutivas ou com estruturas florais muito insignificantes; além da dinâmica que essas plantas apresentam com relação a ambientes antropizados, deixando levantamentos florísticos de determinadas regiões obsoletos; a isso se adiciona o fato de que os botânicos "não gostam de molhar os pés" (Cook et al. 1974). Tudo isso faz com que o estágio de conhecimento das plantas aquáticas, em comparação com outros grupos vegetais, seja bastante incompleto e, como consequência, a literatura para identificação de plantas aquáticas e palustres é escassa.

Irgang \& Gastal Jr. (2003) relataram bem o problema taxonômico existente em algumas famílias de plantas aquáticas e palustres, e acreditaram que, com as investigações taxonômicas em andamento da época, dentro de poucos anos esses problemas estariam resolvidos, porém já se passaram mais de dez anos e esses problemas ainda persistem.

As monocotiledôneas em geral, tanto as aquáticas como as terrestres, são as que ainda oferecem muitas dificuldades de identificação, seja pela falta de monografias, carência de coletas ou basicamente pela ausência e/ou má conservação dos tipos. São necessárias revisões mais atualizadas de importantes famílias neste tipo de ambiente, como Cyperaceae e Juncaceae, além de Ludwigia (Onagraceae) (Irgang \& Gastal Jr. 2003).

As pteridófitas das famílias Isoëtaceae, Marsileaceae e Salvinaceae apresentam problemas diversos, principalmente no que se refere à identificação e ao conhecimento das espécies que ocorrem nos ambientes aquáticos brasileiros. Por exemplo, a espécie Salvinia herzogii, descrita por De La Sota (1962), é a mais abundante no sul do Brasil. Introduzida em outros continentes, acabou recebendo outras denominações, como S. molesta. De La Sota (1996) colocou o nome $S$. herzogii como sinonímia de $S$. biloba, estabelecendo-se, como se nota, enorme confusão a respeito dessa espécie (Camargo et al. 2003).

Para Thomaz \& Bini (2003), o predomínio de levantamentos florísticos entre os trabalhos brasileiros com plantas aquáticas e palustres é um ponto positivo da produção científica sobre esses vegetais, tendo em vista que esses levantamentos contribuem para a quantificação da biodiversidade aquática de nossos ecossistemas. Por outro lado, para Bove et al. (2003), a bibliografia existente sobre plantas aquáticas e palustres não condiz com a grande diversidade dos vegetais hidrófilos, com apenas alguns livros que tratam de plantas aquáticas em geral, distribuídas em diversas partes do mundo.

O levantamento de infestação por plantas aquáticas em reservatórios faz-se necessário, já que permite a análise do grau de infestação e distribuição das diferentes espécies no corpo d'água estudado. A partir desses dados, decisões podem ser tomadas a respeito da maneira mais correta de interagir com essas plantas, desde um simples plano de monitoramento de infestação e distribuição até a aplicação de métodos mais radicais de controle (Martins et al. 2003).

Diante disso e considerando que o reservatório Guarapiranga vem sofrendo com infestações de plantas aquáticas há alguns anos (Pompêo 2008, Pompêo et al. 2008), o presente estudo se faz necessário, pois podemos chamar atenção para a importância da riqueza de espécies que é encontrada em um reservatório urbano e gerar material taxonômico útil para o reconhecimento das espécies nesta e em outras represas semelhantes. Este trabalho, portanto, tem como objetivos avaliar a composição florística das plantas aquáticas e palustres presentes na Represa Guarapiranga e contribuir para o conhecimento taxonômico das espécies.

\section{Material e Métodos}

O estudo foi realizado na Represa Guarapiranga, a qual é uma sub-bacia do Alto Tietê e liga-se a esta através do canal do Rio Pinheiros. Está localizada a uma latitude de $23^{\circ} 43^{\prime} \mathrm{S}$, longitude de $46^{\circ} 32 \mathrm{~W}$ e altitude de $742 \mathrm{~m}$ (Fig.1a). A Bacia Guarapiranga abrange cinco municípios da Grande São Paulo: com $211 \mathrm{~km}^{2}$ no município de São Paulo, $183 \mathrm{~km}^{2}$ em Itapecerica da Serra, $162 \mathrm{~km}^{2}$ em EmbuGuaçu, $41 \mathrm{~km}^{2}$ em Embu e $33 \mathrm{~km}^{2}$ em Cotia. Por isso, a Represa Guarapiranga é considerada um reservatório urbano, já que o município de São Paulo contorna toda margem direita deste reservatório e parte da margem esquerda, perfazendo $70 \%$ do perímetro da represa, com o restante tendo como limites os municípios de Embu-Guaçu (27\%) e Itapecerica da Serra (3\%) Fig.1b (Cetesb 1996).

A represa apresenta um nível operacional mínimo de $726,37 m$ e o máximo é de 736,62 m (Helou \& Silva 1987). A área da represa é de 3618 ha, o volume total de $194 \times 10^{6} \mathrm{~m}^{3}$ e a profundidade média de 7m (Mozeto et al. 2001).

Segundo Beyruth (1996), a Represa Guarapiranga abastece cerca de vinte e um bairros da cidade de São Paulo e também as cidades de Taboão da Serra, Osasco e Carapicuíba, ou seja, é responsável pelo abastecimento da parte sudoeste do município de São Paulo, que abrange mais de 3 milhões de pessoas. Além de servir de abastecimento a represa também tem como função o controle de enchentes, a geração de energia e a recreação (Helou \& Silva 1987)

Em maio/2008, mês em que a cota altimétrica da represa estava alta, foi realizada a navegação em toda margem da represa para localização dos bancos de plantas aquáticas. Nesta ocasião, 20 bancos de coleta foram escolhidos levando em consideração a consistência e acessibilidade do banco e distribuição uniforme por toda represa (Fig. 1c). Os bancos foram georeferenciados com aparelho GPS, obtendo as coordenadas geográficas e localização de cada banco (Tabela 1). 


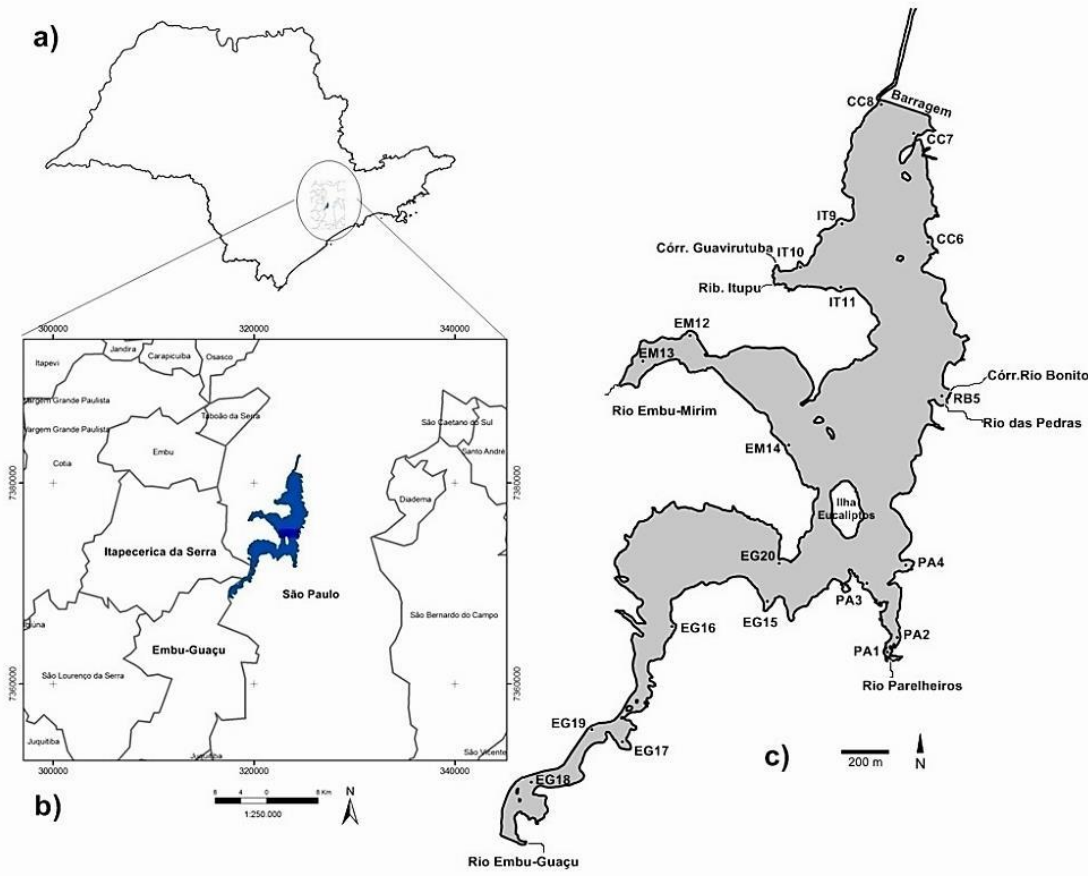

Fig. 1: Área de Estudo: a) Estado de São Paulo; b) Localização da represa nos municípios; c) Represa Guarapiranga com pontos de coleta e principais afluente.

Tabela 1. Localização dos bancos de plantas aquáticas encontrados na Represa Guarapiranga, São Paulo, Brasil.

\begin{tabular}{|c|c|c|c|}
\hline Banco & Localização do Banco & GPS UTM & GPS Graus \\
\hline PA1 & Braço Parelheiros, a $3 \mathrm{Km}$ da foz do Rio Parelheiros & $\begin{array}{l}23 \mathrm{~K} 0324045 / \\
7371583 \\
23 \mathrm{~K} 0324193 /\end{array}$ & $\begin{array}{l}\text { S23o 45.429' / } \\
\text { W46-43.591' } \\
\text { S23 } 45.212^{\prime} \text { ' }\end{array}$ \\
\hline PA2 & Parte mediana do braço Rio Parelheiros & $\begin{array}{l}7371780 \\
23 \mathrm{~K} 0323765\end{array}$ & W46-43.501' \\
\hline PA3 & Inicio do braço Rio Parelheiros & 7372739 & W46눈.749' \\
\hline PA4 & Braço Córrego Tanquinho, em frente a ilha dos Eucaliptos & $\begin{array}{l}23 \mathrm{~K} 0324508 / \\
7373251 \\
23 \mathrm{~K} 0325232 /\end{array}$ & 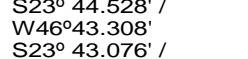 \\
\hline RB5 & Córrego Rio Bonito, na margem contrária do Clube Castelo & $\begin{array}{l}7375939 \\
23 \mathrm{~K} 0324772 /\end{array}$ & 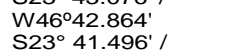 \\
\hline $\mathrm{cc} 6$ & Em frente ao Clube da Eletropaulo, próximo da prainha pública & $\begin{array}{l}7378848 \\
23 \mathrm{~K} 0324611 /\end{array}$ & $\begin{array}{l}\text { W } 46^{\circ} 43.110^{\prime} \\
S 23^{\circ} 40.638^{\prime} /\end{array}$ \\
\hline $\mathrm{CC} 7$ & Barragem oposta à captação de água da Sabesp & $\begin{array}{l}7380433 \\
23 \mathrm{~K} 0323828 /\end{array}$ & $\begin{array}{l}\text { W } 46^{\circ} 43.194^{\prime} \\
\mathrm{S} 23^{\circ} 40.296^{\prime} /\end{array}$ \\
\hline $\mathrm{cc8}$ & Barragem adjacente á captação de água da Sabesp & $\begin{array}{l}7381061 \\
23 K 0323204 /\end{array}$ & $\begin{array}{l}\text { W } 46^{\circ} 43.650^{\prime} \\
\mathrm{S} 23^{\circ} 41.322^{\prime} /\end{array}$ \\
\hline IT9 & Margem da captação de água da Sabesp a $+-2,5 \mathrm{~km}$ & $\begin{array}{l}7379151 \\
23 \mathrm{~K} 0322124 /\end{array}$ & $\begin{array}{l}\text { W46 } 44.034^{\prime} \\
\mathrm{S}^{\circ} 3^{\circ} 41.749^{\prime} /\end{array}$ \\
\hline IT10 & Margem oposta ao Parque Guarapiranga do Braço Itupu & $\begin{array}{l}7378354 \\
23 \mathrm{~K} 0323149 /\end{array}$ & $\begin{array}{l}\text { W } 46^{\circ} 44.673^{\prime} \\
\mathrm{S} 23^{\circ} 42.002^{\prime} /\end{array}$ \\
\hline IT11 & Brejo na entrada do Braço Rio Itupu & $\begin{array}{l}7377896 \\
23 \mathrm{~K} 0320178 /\end{array}$ & $\begin{array}{l}\text { W } 46^{\circ} 44.074^{\prime} \\
\text { S23 }\end{array}$ \\
\hline EM12 & Parque Estadual da Guarapiranga no Braço Embu Mirim & $\begin{array}{l}7377107 \\
23 \mathrm{~K} 376297 /\end{array}$ & $\begin{array}{l}\text { W } 46^{\circ} 45.831^{\prime} \\
\mathrm{S} 23^{\circ} 42^{\prime} 36.68^{\prime \prime} \text { W } 46^{\circ}\end{array}$ \\
\hline EM13 & Braço Embu-Mirim, a $5 \mathrm{Km}$ da foz do Rio Embu-Mirim & $\begin{array}{l}7376297 \\
23 \mathrm{~K} 0321304 /\end{array}$ & $\begin{array}{l}45^{\prime} 56.35^{\prime \prime} \\
\mathrm{S} 23^{\circ} 42.876^{\prime} /\end{array}$ \\
\hline EM14 & Entrada do Braço Embu Mirim & $\begin{array}{l}7376263 \\
23 \mathrm{~K} 0321818 /\end{array}$ & $\begin{array}{l}\text { W } 46^{\circ} 45.174^{\prime} \\
\text { S23 } 44.901^{\prime} /\end{array}$ \\
\hline EG15 & Entre o Braço Parelheiros e Embu-Guaçu & $\begin{array}{l}7372530 \\
23 \mathrm{~K} 0320381 /\end{array}$ & $\begin{array}{l}\text { W46 } 44.896^{\prime} \\
\mathrm{S}^{\prime} 3^{\circ} 45.059^{\prime} /\end{array}$ \\
\hline EG16 & Inicio do Bairro Embu-Guaçu, antes do Rodoanel & $\begin{array}{l}7372221 \\
23 \mathrm{~K} 0319554 /\end{array}$ & $\begin{array}{l}\text { W } 46^{\circ} 45.744^{\prime} \\
\text { S23 }\end{array}$ \\
\hline EG17 & Metade do Braço Embu-Guaçu, depois do Rodoanel a esquerda & 7370302 & W46 $46.244^{\prime}$ \\
\hline EG18 & Final do Braço Embu-Guaçu & $\begin{array}{l}\text { 23K 0317902/ } \\
7369682 \\
23 \mathrm{~K} 0318556 /\end{array}$ & $\begin{array}{l}\mathrm{S}^{\circ} 3^{\circ} 46.416^{\prime} \text { ' } \\
\text { W46 } 46^{\circ} 47.220^{\prime} \\
\mathrm{S}^{\circ} 3^{\circ} 45.838^{\prime} \text { / }\end{array}$ \\
\hline EG19 & Metade do Braço Embu-Guaçu, depois do Rodoanel a direita & $\begin{array}{l}7370760 \\
23 K 0322217 /\end{array}$ & $\begin{array}{l}\text { W46 } 46.829^{\prime} \\
\mathrm{S} 23^{\circ} 44.422^{\prime} /\end{array}$ \\
\hline EG20 & Entre Braço Embu-Guaçu e Embu-Mirim & 7373419 & W46 ${ }^{\circ} 44.655^{\prime}$ \\
\hline
\end{tabular}


Foram realizadas coletas de campo mensais nos 20 bancos de plantas aquáticas durante o período de julho/2008 a junho/2009, abrangendo, com isso, a variação de plantas aquáticas e palustres em um ciclo hidrológico completo (seca e cheia) e verificando a variação das plantas aquáticas entre os bancos amostrados.

A amostragem das comunidades foi definida tendo-se como base o conceito de plantas aquáticas e palustres (Irgang \& Gastal Jr. 1996), as quais foram classificadas de acordo com as formas biológicas propostas por Irgang et al. (1984).

Para evitar a coleta de plantas terrestres sem desconsiderar as plantas palustres anfíbias, foi demarcado um limite nas margens de acordo com a lâmina d'água, e nos meses subsequentes; período que a cota altimétrica estava mais baixa; esses limites não foram ultrapassados.

As técnicas de coleta e preparação de espécimes seguem orientações de Fidalgo \& Bononi (1989), além de Haynes (1984), Pedralli (1990) e Scremin-Dias et al. (1999), mais especificas para plantas aquáticas e palustres.

A fim de verificar a presença de plantas aquáticas submersas foi arrastada uma ferramenta com ganchos ao longo do percurso de cada ponto. Sempre que possível o coletor descia do barco e caminhava para anotar e coletar as plantas anfíbias presentes. Foi utilizado binóculo para verificar presença de espécies mais afastadas e sem possibilidade de aproximação.

Os dados coletados foram complementados com documentação fotográfica dos ambientes e dos espécimes. Assim, os registros fotográficos auxiliaram nas identificações que não foram feitas em campo.

A identificação do material botânico foi realizada através de exame das estruturas a olho nu e sob microscópio estereoscópico, consultas a bibliografia especializada como chaves para famílias: (Souza \& Lorenzi 2005), gêneros (Barroso 1991, 2008, Cook 1996, Longhi-Wagner et al. 2001,Wanderley et al. 2002, 2003, 2005, 2007, 2009); e espécies (bibliografia específica para cada táxon). Foi realizada comparação com exsicatas dos Herbários ESA, SP e SPF, bem como consultas a especialistas.

A coleção principal foi incorporada ao Herbário ESA, com duplicatas de determinadas famílias para os herbários BHCB, FUEL, HUEFS, HURG, ICN, SP, SPF.

O sistema de classificação adotado para as angiospermas foi o Angiosperm Phylogeny Group III (Bremer et al. 2009), para as Samambaias foi o de (Smith et al. 2006) e para as Hepáticas foi utilizado o sistema de classificação de Crandall-Stotler \& Stotler (2000).

As espécies estão apresentadas na Tab. 2 divididas em filos e em famílias, com suas respectivas formas biológicas, origem e endemismo.
Foi elaborada uma chave dicotômica de identificação para as espécies encontradas na área estudada, sendo que no tópico "Descrição das espécies" é fornecida chave para as famílias que apresentam mais de uma espécie no local de estudo.

Para cada espécie é apresentada uma descrição sucinta, baseada no material coletado. Antes de cada descrição são citadas algumas referências bibliográficas onde podem ser encontradas ilustrações e maiores detalhes das espécies. Tais referências também foram utilizadas como base para a distribuição geográfica mundial colocada após a descrição. A distribuição geográfica para os estados brasileiros foi baseada em Forzza et al. (2015). Foi adicionada também a localização das espécies na represa e comentários de caracteres que diferenciam a espécie das demais encontradas no local de estudo.

Como base para os termos morfológicos, foram utilizados Radford et al. (1974) e para terminologia botânica, de forma geral, as propostas apresentadas por Stearn (1983), Font Quer (1989), além de terminologia específica para algumas famílias. Quando espécie ou gênero apresentaram caracteres exclusivos, foram colocados na descrição do táxon, mesmo que não tenha sido referido nas outras descrições.

As abreviaturas dos autores dos binômios, seguiram as recomendações de Brummit \& Powell (1992); a abreviação de periódicos foi feita segundo Bridson \& Smith (1991) e a de obras clássicas taxonômicas segundo Stafleu \& Cowan (1976). Foram citados sinônimos somente quando a espécie em questão sofreu alteração taxonômica recente e/ou quando se tratava de sinônimo muito conhecido e vastamente citado na literatura florística neotropical.

Os nomes vulgares de cada espécie foram extraídos de bibliografia pertinente, as quais foram citadas no texto descritivo, além de outras fontes como Lorenzi (2000) e Kissmann \& Groth (2000) para plantas daninhas e infestantes.

As fotografias de todas as espécies apresentadas neste trabalho estão disponíveis no site http://ecologia.ib.usp.br/macrofita, em Cd Rom e nas figuras deste trabalho são apresentadas somente as imagens de plantas aquáticas e palustres que não foram referidas em Amaral et al. (2008).

\section{Resultados e Discussão}

O levantamento florístico das plantas aquáticas e palustres presentes na Represa Guarapiranga, revelou a existência de 134 taxa, sendo 133 espécies pertencentes a 89 gêneros e 45 famílias (Tabela 2). 
Levantamento de plantas aquáticas e palustres na represa Guarapiranga, São Paulo

Tabela 2. Relação de táxons de plantas aquáticas encontradas na Represa Guarapiranga, São Paulo, Brasil, com sua origem e formas biológicas.

\section{DIVISÕES/FILOS}

Famílias

Especie

MARCANTIOFITAS (HEPÁTICAS)

Ricciaceae

$$
\text { Ricciocarpos natans (L.) Corda }
$$

Flutuante Livre

552,561

\section{MONILOFITAS (SAMAMBAIAS)}

Osmundaceae
Osmunda regalis $\mathrm{L}$.

Salviniaceae

Azolla filiculoides Lam.

Salvinia herzogii de la Sota

Salvinia minima Baker

Salvinia cf molesta D.S. Mitch.
Nativa

\section{Formas Biológicas}

Origem

Anfíbia

Flutuante Livre

Flutuante Livre

Flutuante Livre

Flutuante Livre
Nativa

Nativa

Nativa

Endêmica do Brasil

Nativa
Número do coletor

MAGNOLIOFITAS (ANGIOSPERMAS)

Alismataceae

Sagittaria montevidensis Cham. \& Schltdl.

Emergente

Nativa

$306,344,348,402$

Amaranthaceae

Alternanthera philoxeroides (Mart.) Griseb.

Emergente

Nativa

$26,33,34,87,121,439$

Apiaceae

Centella asiatica (L.) Urb.

Anfíbia

Flutuante Livre

Flutuante Livre

Nativa

Nativa

Nativa

Nativa

Nativa

Nativa

Nativa

Nativa

Nativa

Nativa

Nativa

Nativa

Subespontânea

Nativa

Nativa
347,524

$200,406,419,568$

$415 a$

197,567
Asteraceae
Ambrosia artemisiifolia L.

crispa Spreng.

Conyza canadensis (L.) Cronquist

Eclipta prostrata (L.) L

Enydra anagallis Gardner

Ethulia conyzoides L. $\mathrm{f}$.

Pluchea sagittalis (Lam.) Cabrera

Sphagneticola trilobata (L.) Pruski
Emergente

Anfíbia

Emergente

Anfíbia
564

353,562

2, 52

492

$120,332,434,554$

$333,420,429,518$, $415 \mathrm{~b}$

223, 266, 315, 393

318,463

374

479

465

$112,221,280$

5, 11, 20, 57, 70, 71,

$81,115,411$

$94,209,244$

$32,41,89$

206, 258, 264

Begoniaceae

Nativa

269,373

Bol. Bot. Univ. São Paulo, São Paulo, v. 35, p. 1-64, 2017 
M. E. F. Rodrigues et al.

\section{DIVISÕES/FILOS}

Famílias

Espécies

Formas Biológicas Origem

Número do coletor

Boraginaceae

Euploca filiformis (Lehm.) J.I.M.Melo \& Semir

Anfíbia

Nativa

Euploca lagoensis (Warm.) Diane \& Hilger

Anfíbia

Nativa

Euploca procumbens (Mill.) Diane \& Hilger

Anfíbia

Nativa

243, 432, 495

Heliotropium elongatum (Lehm.) I.M. Johnst.

Anfíbia

Nativa

Campanulaceae

Lobelia exaltata Pohl

Emergente

Endêmica do Brasil

Cleomaceae

Tarenaya hassleriana (Chodat) H. H. Iltis

Anfíbia

Nativa

$119,133,226,253$

Commelinaceae

Commelina diffusa Burm. $f$.

Anfíbia

Nativa

$18,44,229,249$,

Convolvulaceae

Ipomoea carnea Jacq.

Emergente

Nativa

$116,349,362$

Cyperaceae

Carex polysticha Boeckeler

Anfíbia

Nativa

484

Cyperus entrerianus Boeckeler

Anfíbia

Nativa

Cyperus haspan L.

Anfíbia

Nativa

Cyperus imbricatus Retz.

Anfíbia

Nativa

Cyperus intricatus Schrad. ex Schult.

Anfíbia

Nativa

Cyperus mundtii (Nees) Kunth

Emergente

Nativa

Cyperus odoratus L.

Emergente

Nativa

Cyperus pohlii (Nees) Steud.

Anfíbia

Cyperus surinamensis Rottb.

Emergente

Nativa

Nativa

Eleocharis bonariensis Nees

Emergente

Nativa

Eleocharis flavescens (Poir.) Urb.

Emergente

Eleocharis interstincta (Vahl) Roem. \&

Emergente

Schult.

Emergente

Eleocharis maculosa (Vahl) Roem. \& Schult.

Eleocharis minima Kunth

Emergente

Eleocharis montana (Kunth) Roem. \& Schult

Eleocharis sellowiana Kunth

Emergente

Emergente

Eleocharis subarticulata Boeckeler

Emergente

Fimbristylis squarrosa Vahl

Anfíbia

Nativa

Nativa

Nativa

Nativa

Nativa

Nativa

Nativa

Nativa

Anfíbia

Nativa

Kyllinga brevifolia Rottb.

Anfíbia

Nativa

Nativa

Oxycaryum cubense (Poepp. \& Kunth) Palla

Epífita

Nativa

Pycreus lanceolatus (Poir.) C.B. Clarke

Anfíbia

Nativa

Rhynchospora corymbosa (L.) Britton

Anfíbia

Nativa

Rhynchospora holoschoenoides (Rich.)

Anfíbia

Nativa

Rhynchospora riparia (Nees) Boeckeler

Anfíbia

Nativa

Scleria distans Poir

Anfíbia

Nativa

352b, 446b, 455

425,453

366

485

$85,379,413,456$

$14,103,307,328$

480

237, 352a, 507

431

21, 194, 461a, 547

$54,187,458$

$337,526,559$

$461 \mathrm{~b}$

437

$331,471,499,558$

512,533

$239,430,538$

510,531

546

491

$494,498,541$

95, 527

23, 422, 454, 497,

46,271

505,532

525

Eriocaulaceae

Syngonanthus caulescens (Poir.) Ruhland

Anfíbia

Nativa

427,535 


\section{DIVISÕES/FILOS \\ Famílias}

Espécies

Formas Biológicas Origem

Número do coletor

Fabaceae

Aeschynomene sensitiva var. hispidula Rudd Anfíbia

Nativa

105, 346, 350

Desmodium adscendens (Sw.) DC.

Anfíbia

Naturalizada

320,515

Sesbania virgata (Cav.) Pers.

Anfíbia

Nativa

88,91

Vigna luteola (Jacq.) Benth.

Anfíbia

Nativa

270, 370, 449

Haloragaceae

Myriophyllum aquaticum (Vell.) Verdc.

Submersa Fixa

Nativa

$1,92,131,335$

Hydrocharitaceae

Egeria densa Planch.

Limnobium laevigatum (Humb. \& Bonpl. ex Willd.) Heine

Submersa Fixa

Nativa

222, 345

Flutuante Livre

Nativa

Hypericaceae

Hypericum brasiliense Choisy

Anfíbia

Nativa

424

Hypericum mutilum $\mathrm{L}$.

Anfíbia

Nativa

443, 469

Iridaceae

Sisyrinchium commutatum Klatt

Anfíbia

Nativa

294

Sisyrinchium micranthum Cav.

Sisyrinchium vaginatum Spreng.

Anfíbia

Nativa

234, 293, 295, 301,

$468,520,548$

Anfíbia Nativa

$395,408,426,475$

Juncaceae

Juncus microcephalus Kunth

Anfíbia

Nativa

$268,282,414,423$,

452, 457, 482, 493 ,

Lentibulariaceae

Utricularia foliosa $\mathrm{L}$.

Submersa Fixa

Nativa

8, 43, 195, 199

Utricularia gibba L.

Submersa Fixa

Nativa

$6,13,460,489$,

Linderniaceae

Lindernia rotundifolia (L.) Alston
Micranthemum umbrosum (J.F. Gmel.) S.F.
Blake

Anfíbia

Nativa

$25,230,334$

Anfíbia

Nativa

196, 400, 433

Lythraceae

Cuphea carthagenensis (Jacq.) J.F. Macbr.

Anfíbia

Nativa

$211,241,284,544,549$

Melastomataceae

Acisanthera variabilis (DC.) Triana

Anfíbia

Nativa

$448 \mathrm{a}$

Tibouchina herbacea (DC.) Cogn.

Anfíbia

Nativa

$101,356,372,448 b$

Menyanthaceae

Nymphoides humboldtiana (Kunh) Kuntze

Flutuante Fixa

Nativa

125

Nymphaeaceae

Nymphaea caerulea Savigny

Flutuante Fixa

Subespontânea

$56,123,184$

Ochnaceae

Sauvagesia erecta L.

Anfíbia

Nativa

300,516

Onagraceae

Ludwigia elegans (Cambess.) H. Hara

Anfíbia

Nativa

$16,188,474$

Bol. Bot. Univ. São Paulo, São Paulo, v. 35, p. 1-64, 2017 


\begin{tabular}{l} 
DIVISÕES/FILOS \\
Famílias \\
Espécies \\
\hline $\begin{array}{l}\text { Ludwigia grandiflora (Michx.) Greuter \& } \\
\text { Burdet }\end{array}$ \\
Ludwigia leptocarpa (Nutt.) H. Hara \\
Ludwigia longifolia (DC.) H. Hara \\
Ludwigia octovalvis (Jacq.) P.H. Raven \\
Ludwigia peploides subsp. montevidensis \\
(Spreng.) P.H. Raven \\
Ludwigia peploides autor subsp.. peploides \\
Ludwigia sp.
\end{tabular}

Orchidaceae

Habenaria paulistana J.A.N.Bat. \& Bianch.

Orobanchaceae

Agalinis communis (Cham. \& Schltdl.)

D'Arcy

Phrymaceae

Mazus pumilus (Burm. f.) Steenis

Plantaginaceae

Bacopa lanigera Wettst.

Gratiola peruviana L.

Nuttallanthus canadensis (L.) D.A. Sutton Mecardonia procumbens var. caespitosa (Cham.) V.C.Souza

Veronica javanica Blume

Poaceae

Andropogon bicornis L.
Echinochloa crus-galli (L.) P. Beauv.
Echinochloa polystachya (Kunth) Hitchc.
Eragrostis hypnoides (Lam.) Britton, Sterns
\& Poggenb.
Eragrostis mexicana (Hornem.) Link
Hymenachne amplexicaulis (Rudge) Nees
Hymenachne pernambucensis (Spreng.)
Zuloaga
Panicum repens L
Paspalum urvillei Steud.
Reimarochloa acuta (Fluggé) Hitchc.
Setaria parviflora (Poir.) Kerguélen
Setaria sphacelata (Schumach.) Stapf \&
C.E. Hubb. ex M.B. Moss
Urochloa arrecta (Hack. ex T. Durand \&
Schinz) Morrone \& Zuloaga
Urochloa mutica (Forssk.) T.Q. Nguyen

Anfíbia

Emergente

Emergente

Anfíbia

Emergente

Emergente

Emergente

Emergente

Anfíbia

Anfíbia

Anfíbia

Anfíbia

Emergente

Emergente

Polygonaceae

Polygonum acuminatum Kunth

Polygonum ferrugineum Wedd.

Polygonum hydropiperoides Michx.
Nativa

Nativa

Nativa

Nativa

Nativa

Nativa

Nativa

Endêmica do Brasil

$104,247,530$

Nativa

Subespontânea

467,550

Endêmica do Brasil

Nativa

Naturalizada

Endêmica do Brasil

Naturalizada

Nativa

Naturalizada

Nativa

Nativa

Nativa

Nativa

Nativa

Subespontânea

Nativa

Nativa

Subespontânea

Nativa

Subespontânea

Subespontânea

Nativa

Nativa

Nativa
$302,428,451,517$

$232,235,277,286$, 487,508 , 503,536

316

385

$323,459,509,523,534$

338

236,542

$386,387,410,441$

$341,354,417$

$86,124,375$

$98,377,382,389,481$, 511,555 ,

483

$506 \mathrm{a}$

$326,501,506 b$

343,551

$202,339,383,421,522$

560

396,513

$83,126,553,340,342$, $363,364,368$

$84,216,238,281,303$, $392,436 \mathrm{~b}, 543$ 
DIVISÕES/FILOS

Famílias

Espécies
Polygonum paraguayense Wedd.

Polygonum punctatum Elliott

Rumex obtusifolius L.

Eichhornia crassipes (Mart.) Solms.

Heteranthera reniformis Ruiz \& Pav.

Pontederia cordata L.

Primulaceae

Lysimachia minima (L.) U. Manns \& Anderb.
Pontederiaceae

Formas Biológicas

Emergente

Emergente

Emergente

Flutuante Livre

Emergente

Anfíbia

Anfíbia

Anfíbia

Anfíbia

Coccocypselum capitatum (Graham) C.B. Costa \& Mamede

Diodia saponariifolia (Cham. \& Schltdl.) K. Schum.

Oldenlandia salzmannii (DC.) Benth. \&

Hook. f. ex B.D. Jacks.

Solanaceae

Nicotiana longiflora Cav.

Nicotiana sp.

Typhaceae

Typha latifolia L.

Urticaceae

Boehmeria cylindrica (L.) Sw.

Xyridaceae

Xyris laxifolia Mart.

Zingiberaceae

Hedychium coronarium J. König
Anfíbia

Anfíbia

Emergente

Emergente

Emergente

Anfíbia

Nativa

Nativa

Nativa

Nativa

Emergente

Nativa

Subespontânea
412

Número do coletor

$96,128,129,203,204$,

$215,224,262,272$,

$390,398,401,405$,

$407,436^{\mathrm{a}}$

$201,317,435,445$,

$12,35,565$

488

478

563

$214,254,378,384$

466,496

462,473

$191,275,297,388$ 416,418 ,

313

314

$90,118,122,198,310$

322,514
A riqueza de espécies de plantas aquáticas e palustres revelada para a Represa Guarapiranga através do presente trabalho pode ser considerada alta, principalmente quando comparada com outros trabalhos exclusivos de plantas aquáticas e palustres em reservatórios, como por exemplo, o levantamento feito por Thomaz \& Bini (1999), no reservatório de Itaipu binacional, no qual registrou a presença de 62 espécies, Dellelo (2008) registrou 62 espécies no reservatório do Lobo-SP, Lolis (2008) no reservatório Eduardo Magalhães em Tocantins registrou 50 espécies, Tavares (2003) levantou em seis reservatórios do médio e baixo Rio Tietê a presença de 47 espécies.

A diferença no número de espécies fica ainda mais evidente quando comparado a trabalhos que possuem coletas em apenas uma época do ano e que não consideram as espécies anfíbias, como por exemplo, de Martins et al. (2008), o qual realizou o levantamento de plantas aquáticas e palustres em 18 reservatórios no estado de São Paulo e registrou a presença de 39 espécies, Tanaka et al. (2002) realizou o levantamento em cinco reservatórios do Estado de São Paulo e registrou 29 espécies, Martins et al. (2003) em 3 reservatórios no Rio de Janeiro registrou 11 espécies, Carvalho et al. (2003) registrou a presença de 17 espécies no reservatório de Barra Bonita-SP e Martins et al. (2009) no reservatório em Porto Primavera registrou 18 espécies.

Segundo Bove et al. (2003) existe uma necessidade em incluir as espécies anfíbias nos estudos de flora aquática, pois, às vezes a delimitação 
dos tipos biológicos não é bem definida, além de caracterizar de forma mais adequada estes ambientes. Por isso é necessário estar muito atento ao objetivo do estudo para a escolha certa do sistema de classificação a adotar, já que os estudos que incluem as espécies anfíbias permitem englobar maior número de espécies e evitar a exclusão de possíveis plantas aquáticas e palustres, e os sistemas que não incluem permitem uma caracterização ecológica da comunidade de plantas aquáticas e palustres, sendo mais voltada para relação delas com o ambiente aquático evitando com isso a coleta de espécies terrestres que possam distorcer os resultados.

No entanto, ao optar por sistemas que incluem espécies anfíbias é importante estabelecer limites nas zonas litorâneas do local estudado para que espécies terrestres não sejam incluídas no levantamento. No presente trabalho foram excluídas 37 espécies coletadas durante a execução do trabalho, que posteriormente, após uma análise mais cuidadosa, foram consideradas como terrestres.

Geralmente o número de espécies com a forma biológica anfíbia e emergente é maior que o das demais formas biológicas nos trabalhos de plantas aquáticas e palustres, ocorrendo o mesmo no atual estudo. Isso porque as anfíbias possuem adaptações tanto para o ambiente aquático quanto para o terrestre (Irgang \& Gastal Jr. 1996) e as emergentes porque ficam localizadas na região marginal, áreas de grande produtividade e diversidade de espécies e também onde são encontradas as maiores concentrações de nutrientes (Wetzel \& Likens 2000).

Dos 134 taxa, foram identificadas em nível específico 132 (98,51\%) e duas (Nicotiana e Ludwigia) permaneceram em nível genérico $(1,49 \%)$ por falta de material reprodutivo para a identificação, assim como uma espécie que precisa ser confirmada (Salvinia cf. molesta). Até variedade foram identificadas seis espécies, tendo uma mesma espécie "Ludwigia peploides" duas variedades.

A porcentagem de identificação até o nível específico no atual trabalho foi alto (98\%), principalmente quando comparado com alguns trabalhos de plantas aquáticas e palustres (Tavares 2003, Viana 2005, Delello 2008), os quais possuem entre $30-35 \%$ das identificações até o nível genérico ou com espécies para confirmar.

A literatura voltada para identificação de plantas aquáticas e palustres é escassa, sendo identificadas por botânicos profissionais até o nível de gênero através da obra de Cook (1996), tornando-se a identificação no nível específico, mais problemática (Amaral et al. 2008), apesar de ter sido amenizado por alguns Guias de Campos lançados recentemente (Pott \& Pott 2000, Amaral et al. 2008, Bove \& Paz 2009). Segundo Tanaka et al. (2002), a dificuldade de identificação correta das espécies no levantamento de plantas aquáticas e palustres feito por eles deveu-se principalmente à pequena quantidade de referências bibliográficas nacionais. Diante desses problemas houve a motivação em elaborar uma chave de identificação e descrições das espécies registradas no presente trabalho.

A família Cyperaceae foi a mais difícil de identificar, pela semelhança entre as espécies, por não estarem disponíveis chaves específicas. A mesma dificuldade foi citada por Tavares (2003), além de ser notada em outros trabalhos (Tanaka et al. 2002, Tavares 2003, Bini et al. 2005, Viana 2005, Delello 2008, Lolis 2008, Martins et al. 2008) que possuem ao menos um indivíduo identificado somente até o gênero na família.

As famílias com maior número de espécies foram Cyperaceae com 27 espécies, seguida de Poaceae (14), Asteraceae (10), Onagraceae (7), Polygonaceae (6) e Plantaginaceae (5), as demais famílias apresentaram valores abaixo de 5 espécies, sendo que $58 \%$ das famílias apresentaram apenas 1 espécie. Na Fig.2 é possível verificar demais detalhes sobre quantidade de espécies e gêneros por família.

$\mathrm{Na}$ maioria dos trabalhos realizados com plantas aquáticas e palustres, incluindo Irgang et al. (1984), Brandão et al. (1989), Pott et al. (1989), Pedralli et al. (1993a) e (1993b), Pott \& Pott (2000), França et al.(2003), Matias et al. (2003), Tavares (2003), Delello (2008), Lolis (2008) Cyperaceae e Poaceae aparecem entre as três principais famílias em relação à riqueza específica. No presente estudo esta mesma tendência se manteve.

Existem razões para se esperar que as famílias Cyperaceae e Poaceae tenham maior riqueza de espécies, já que é estimado que possuam, respectivamente, mais de 5000 e 10000 espécies (Watson \& Dallwitz 1992, Goetghebeur 1998) com $30 \%$ e $9 \%$ dos gêneros tendo espécies aquáticas (Cook 1999; Rutishauser com. pess. 2010), além de possuírem sistema subterrâneo complexo formado por rizomas e tubérculos, com algumas dispondo de estolhos subterrâneos, permitindo eficiente propagação vegetativa e, consequentemente, representando espécies competitivamente dominantes (Goetghebeur 1998). 


\section{Espécies e Gêneros x Família}

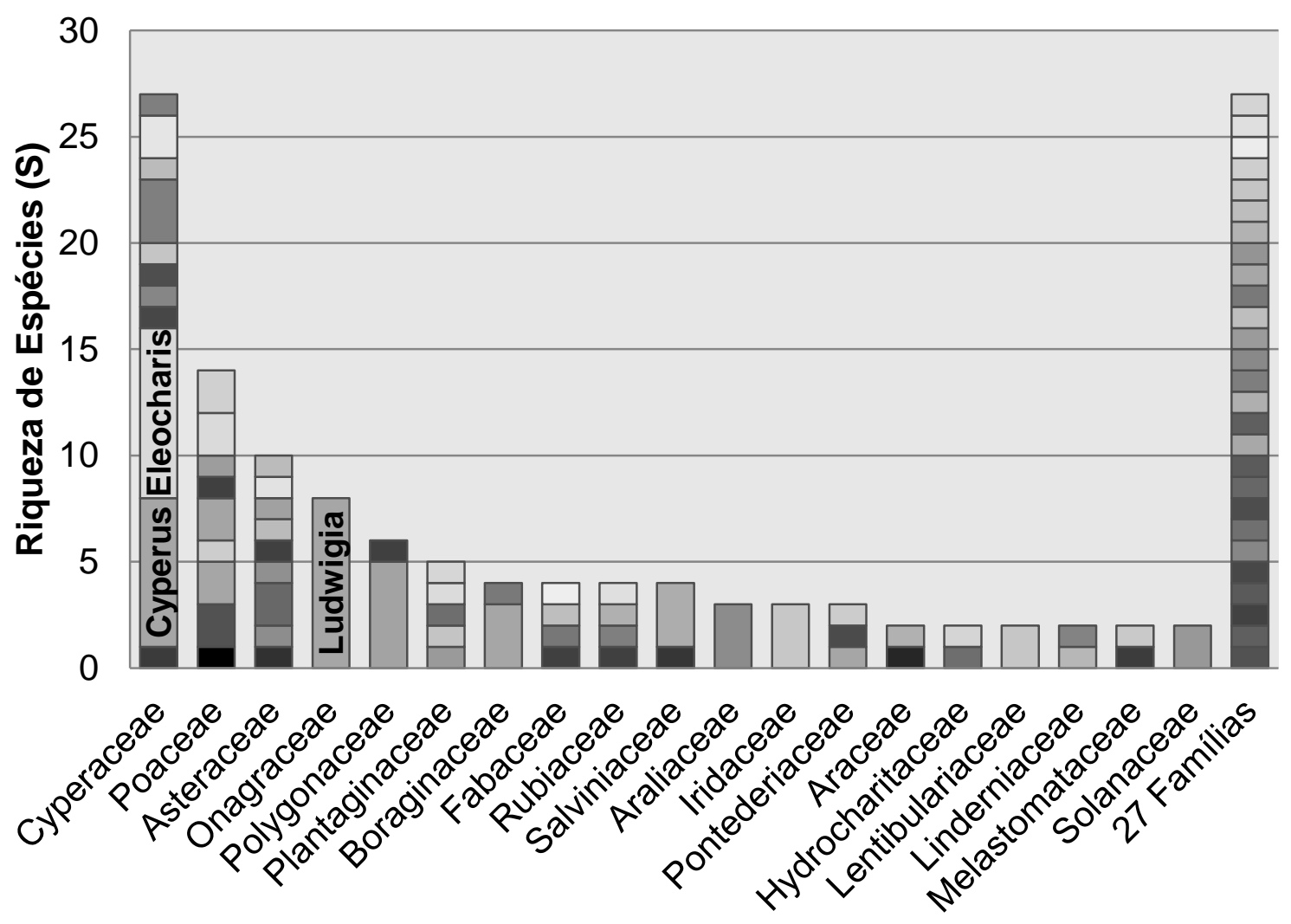

Fig. 2: Número de gêneros e espécies de macrófitas aquáticas por família presentes na Represa Guarapiranga. Cada cor nas colunas representa um gênero diferente.

As famílias Cyperaceae, Poaceae e Asteraceae apresentaram também o maior número de gêneros com 11 e 9 respectivamente, seguidas de Plantaginaceae com 5 gêneros. O gênero com maior número de espécies foi Eleocharis com 8 espécies seguida de Cyperus e Ludwigia com 7 e Polygonum com 5 (Fig.2).

Segundo Cook (1999), a tribo Eleocharideae é considerada exclusivamente aquática, explicando assim o fato de Eleocharis ser bem representado no presente levantamento. Junto com Eleocharis os gêneros Cyperus, Ludwigia e Polygonum apresentam maior riqueza específica nos levantamentos com plantas aquáticas e palustres. Verifica-se que pelo menos três destes quatro gêneros ocorrem em alguns levantamentos de plantas aquáticas e palustres anteriormente realizados no Brasil (Tanaka et al. 2002, Carvalho et al. 2003, Tavares 2003, Bini et al. 2005, Delello 2008, Lolis 2008, Martins et al. 2008, Martins et al. 2009) com excessão de Martins et al. (2003), o qual constata a presença somente de Polygonum. Deve ser, ainda, salientado que nos estudos que incluíram espécies anfíbias, os gêneros Cyperus, Eleocharis e Ludwigia tiveram maior riqueza específica (Tavares 2003, Delello 2008, Lolis 2008).

Das 133 espécies identificadas apenas Ricciocarpos natans pertence ao grupo das Hepáticas, cinco espécies são Samambaias e as demais 127 são Angiospermas.

O número de famílias e gêneros que possuem espécies de plantas aquáticas em Briófitas s.l. (11 e 22) e Pteridófitas s.l. $\left(\begin{array}{lll}9 & \text { e } & 11\end{array}\right)$ é significativamente inferior ao de Angiospermas (103 e 440) (Cook 1999). Por isso, os levantamentos de plantas aquáticas e palustres possuem riqueza específica muito mais elevada em Angiospermas do que em Briófitas s.l. e Pteridófitas s.l.

No sistema de classificação de CrandallStotler \& Stotler (2000), a espécie $R$. natans está na classe Marchantiopsida, na subclasse Marchantiidae e ordem Ricciales.

No sistema de classificação de Smith et al. (2006) as Samambaias identificadas no presente estudo pertencem a classe Polypodiopsida, tendo 
apenas a espécie Osmunda regalis na ordem Osmundales e demais espécies na ordem Salviniales. Segundo a classificação APGIII das 127 espécies de angiospermas identificadas apenas uma delas é Angiosperma Basal (Nymphaea caerulea), 59 são Monocotiledôneas e 67 estão como Eudicotiledôneas.

Segundo levantamento feito por Cook (1999) e Rutishauser (com. pess. 2010) foi possível verificar que entre os principais grupos de angiospermas existem proporcionalmente mais aquáticas em monocotiledôneas do que nas demais angiospermas. No presente estudo a mesma proporção foi encontrada, tendo através da classificação APGIII entre as ordens, $41 \%$ de Monocotiledôneas e 35,7\% de Eudicotiledôneas, aumentando essa diferença entre as famílias com $14,4 \%$ e $8 \%$ respectivamente. Importante destacar que metade das espécies $(50,3 \%)$ registradas não é considerada daninha ou infestante, sendo uma porcentagem alta, pois as plantas aquáticas e palustres geralmente são vistas dessa forma em ambientes antropizados, como reservatórios, hidrelétricas e outros empreendimentos, devido aos problemas que ocasionam quando ocorre profileração delas.

Assim é possível afirmar que as plantas aquáticas e palustres não devem ser extirpadas do reservatório como pragas, mas ao contrário, devem ser despendidos esforços para que permaneçam nos ecossistemas e que tenham seu crescimento controlado. Evitando os efeitos danosos do crescimento explosivo e para que não ocorram abruptas reduções de sua área de colonização e biomassa (Pompêo et al. 2008).

Ao considerar também que a Represa Guarapiranga é um ambiente muito antropizado, esperava-se uma quantidade maior de plantas daninhas e infestantes. Henry-Silva et al. (2010) verificou que $47,5 \%$ das espécies identificadas na Bacia Hidrográfica do Rio Apodi/Mossoró são oportunistas e atribuiu a isso um indicativo de que a região é menos preservada, fornecendo condições favoráveis para a colonização de espécies daninhas em potencial. Bove (2003) observou a presença de $23 \%$ das espécies como daninhas em ecossistemas aquáticos temporários e bem preservados da Planície Costeira do Estado do Rio de Janeiro.

Das 67 espécies consideradas plantas daninhas ou infestantes (Kissmann \& Groth 2000, Lorenzi 2000), apenas 14 são subespontâneas ou naturalizadas (Barroso 1952, Forzza et al. 2015) as demais 120 espécies são nativas, sendo 6 endêmicas do Brasil (Forzza et al. 2015), com destaque para Habenaria paulistana, por ser a única macrófita do presente trabalho endêmica do estado de São Paulo (Batista et al. 2006, Barros et al. 2015).

Considerando que a Represa Guarapiranga se encontra imersa em uma área urbana, poderia supor que fosse encontrada uma quantidade alta de espécies exóticas. Entretanto, encontrou-se uma pequena quantidade de espécies exóticas e subespontâneas, tendo predominado as espécies nativas. Além disso, dentre as espécies exóticas somente duas possuem potencial de infestação na represa, Panicum repens e Urochloa arrecta, pois apresentaram alta frequência e abundância na local de estudo. Assim, pode-se inferir que as estratégias de manejo direcionadas em incrementar a colonização por espécies nativas visando a aumentar o grau de estruturação espacial do habitat e reduzir a possibilidade de colonização por espécies introduzidas (ou exóticas) com elevado potencial de infestação podem ser realizadas com uma facilidade maior do que originalmente poderia-se supor (Madsen 2000, Bini 2001 apud Thomaz et al. 2003).

Das espécies identificadas 53 não constam no Guia de Campo para Plantas Aquáticas e Palustres do Estado de São Paulo (Amaral et al. 2008). Porém, dessas espécies, 15 são anfíbias e constam como invasoras e daninhas em Lorenzi (2000) e Kissmann \& Groth (2000), motivo pelo qual provavelmente não estão referidas em Amaral et al. 2008. De qualquer forma, pode ser considerado o acréscimo de pelo menos 38 espécies (Figs. 3, 4 e 5) de plantas aquáticas e palustres para o estado de São Paulo através do presente trabalho.

Considerando-se as famílias descritas até o momento para a Flora de São Paulo (Longhi-Wagner et al. 2001, Wandeley et al. 2002-2009), podemos destacar a ausência apenas de Reimarochloa acuta (Poaceae) a qual também não consta para o estado de São Paulo na Lista da Flora do Brasil (Filgueiras et al. 2016). Outras 4 espécies: Mazus pumilus, Nuttallanthus canadensis, Veronica javanica e Urochloa arrecta não constam na Flora de São Paulo porque são subespontâneas e não foram incluídas pelos respectivos autores.

As espécies: Salvinia herzogii, Lemna aequinoctialis, Ludwigia grandiflora, Ludwigia peploides e Reimarochloa acuta não são referidas para o estado de São Paulo na Lista da Flora do Brasil (Forzza et al. 2015), embora Lemna aequinoctialis ser referida em Wandeley et al. (2001-2009) e Amaral et al. (2008).

Apesar do número de espécies endêmicas do Brasil e do estado de São Paulo ser baixo, o presente levantamento não deixa de ser importante, já que contribui significativamente para a Flora de plantas aquáticas e palustres, bem como para Lista da Flora do Brasil, registrando espécies que não constavam anteriormente para o estado de São Paulo.

Os resultados evidenciam que levantamentos florísticos são importantes, pois colaboram tanto como subsídio para preservação da biodiversidade quanto para o manejo adequado desses vegetais, podendo oferecer importantes informações do ponto de vista comparativo, fator já destacado por Viana (2005). 


\section{Chave para identificação das espécies de plantas aquáticas e palustres da represa Guarapiranga}

1. Plantas não enraizadas

2. Folhas com superfície adaxial híspida ou pubescente

3. Folhas em rosetas com aerênquima (esponjosas), nervuras evidentes e paralelas

3'. Folhas em verticilos de 3, não esponjosas (sem aerênquima), sem nervuras evidentes e paralelas

4. Tricomas com ápice livre ("pé-de-galinha") .....

11. Pistia stratiotes

4'. Tricomas com ápice unido ("pá-de-batedeira")

5. Folhas dobradas e erguidas, sem tricomas na face abaxial

5. Salvinia minima

5'. Folhas abertas, com muitos tricomas castanhos na face abaxial

4. Salvinia herzogii

lhas com superfície adaxial glabra

6. Folhas com aerênquima (esponjosas) no pecíolo ou lâmina

7. Lâmina foliar com aerênquima (esponjosa), base do pecíolo sem aerênquima

7'. Lâmina foliar sem aerênquima, base do pecíolo com aerênquima (esponjosa)

6'. Folhas sem aerênquima

8. Folhas menores que $1 \mathrm{~mm}$ de compr., imbricadas, escamiformes

8'. Folhas maiores que $1 \mathrm{~mm}$ de compr., não imbricadas nem escamiformes

9. Plantas com caule e folhas diferenciados, folhas reniformes com margem crenada.

9'. Plantas com caule e folha não diferenciados, folhas ovais ou cordadas, margem lisa

10. Plantas com até $0,3 \mathrm{~cm}$ de compr.

10. Plantas de 1,0 a $1,5 \mathrm{~cm}$ de compr.

1'. Plantas enraizadas

11. Folhas flutuantes

12. Face abaxial da lâmina com glândulas castanhas, nervação não evidente

12'. Face abaxial da lâmina com manchas negras ou púrpuras, nervação evidente

11'. Folhas submersas ou emersas (inclui plantas emergentes e anfíbias)

13. Plantas com folhas inconspícuas ou reduzidas a bainha

14. Arbustos ou subarbustos ramificados desde a base, ramos alados

68. Limnobium laevigatum

121. Eichhornia crassipes

14'. Ervas não ramificadas ou ramificadas apenas na base, ramos não alados Eleocharis - Chave em Cyperaceae pg. 28

13'. Plantas com folhas conspícuas

15. Folhas com nervação paralelódroma, actinódroma, campilódroma ou pinado-paralela, presença de bainha (monocotiledôneas)

16. Nervação pinado-paralela

134. Hedychium coronarium

16'. Nervação paralelódroma, actinódroma ou campilódroma

17. Folhas ovais, reniformes ou sagitadas

18. Folhas com base hastada

18'. Folhas com base cordada

19. Lâmina foliar reniforme, de $1-3,5 \mathrm{~cm}$ de compr.

7. Sagittaria montevidensis

19'. Lâmina foliar oval, de $22 \mathrm{~cm}$ de compr.

122. Heteranthera reniformis

17 '. Folhas lanceoladas, elípticas, lineares

20. Secção transversal do caule triangular 123. Pontederia cordata

20'. Secção transversal do caule circular ou achatada

21. Folhas dispostas na base da planta

22. Lâminas foliares cilíndricas, ocas, septos transversais

22'. Lâminas foliares planas, sem septos transversais

23. Plantas robustas, de 80 a $200 \mathrm{~cm}$ alt.

24. Lâminas com estrias avermelhadas, sem aerênquima, base das folhas avermelhada, bainhas alargadas na base, vermelhas a castanho-escuras, margem hialina ........................................................................... 133. Xyris macrocephala

24'. Lâminas sem estrias avermelhadas, com aerênquima, base das folhas verde, bainhas não alargadas na base, verdes e escariosas 131. Typha latifolia

23'. Plantas de pequeno porte, até $30 \mathrm{~cm}$ alt.

25. Presença de uma bráctea tectriz no ápice do escapo plano 71. Sisyrinchium commutatum

25 '. Presença de diversas brácteas alternas ao escapo plano 72 . Sisyrinchium micranthum

21'. Folhas dispostas ao longo do caule

26. Plantas com lígula

Chave em Poaceae - pg. 48

26'. Plantas sem lígula

27. Filotaxia alterna dística

28. Folhas linear-ensiformes, escamiformes

28'. Folhas lanceoladas, não escamiformes

29. Folhas de $2-5 \mathrm{~cm}$ de compr., margens lisas, flores vistosas com pétalas azuis ................................................................... 32. Commelina

29'. Folhas de 7-30cm de compr., margens escabras, flores inconspícuas com gluma verde a violácea .............................................102. Echinochloa crus-galli

27 '. Filotaxia alterna espiralada

30. Plantas maiores que $80 \mathrm{~cm}$ de alt., flores vistosas

93. Habenaria paulistana

30'. Plantas menores que $30 \mathrm{~cm}$ de alt., flores inconspícuas .61. Syngonanthus caulescens 
15'. Folhas com nervação craspedódroma, camptódroma, eucamptódroma, broquidódroma, cladódroma, acródroma, actinódroma, hifódroma ou flabelada, bainha ausente

31. Folhas (ou frondes) compostas (Fabaceae e Osmundaceae)

32. Folhas trifolioladas

33. Plantas prostradas, folíolos orbiculares, estipelas ausentes

63. Desmodium adscendens

33'. Plantas volúveis, folíolos ovais, estipelas presentes 65. Vigna luteola

32'. Folhas (ou frondes) pinadas

34. Folhas sem estípula, folíolos com nervuras sobressalentes em ambas as faces, nervação flabelada (dicotômica), margem serrilhada

2. Osmunda regalis

34'. Folhas com estípula, folíolos sem nervuras sobressalente em ambas as faces, nervação camptódroma e/ou reticulódroma, margem inteira

35. Folhas $12-24 \mathrm{~cm}$ compr., folíolos de 1,4-2,8x0,6-1,0cm

64. Sesbania virgata

35 . Folhas $1-5 \mathrm{~cm}$ compr, folíolos de $0,07-0,17 \times 0,7-0,15 \mathrm{~cm}$

2. Aeschynomene sensitiva

31'. Folhas simples, inteiras, pinatífidas, palmatissectas, pinatissectas ou dicotomicamente ramificadas

36. Plantas com utrículos

37. Plantas com utrículos evidentes, estolão achatado, mucilaginoso

75. Utricularia foliosa

37'. Plantas com utrículos pequenos, estolão circular, sem mucilagem

76. Utricularia gibba

36'. Plantas sem utrículos

38. Folhas partidas

39. Folhas palmatissectas junto com folhas inteiras no ápice do caule

39'. Folhas não palmatissectas

40. Plantas rastejantes a ascendentes, folhas verticiladas e pinatissectas, planta geralmente submersa .

66. Myriophyllum aquaticum

40'. Plantas eretas, folhas inferiores opostas e superiores alternas e pinatífidas, planta palustre

16. Ambrosia artemisiifolia

38'. Folhas inteiras

41. Folhas assimétricas.

25. Begonia fischeri

41'. Folhas simétricas

42. Folhas orbiculares, reniformes, cordadas ou ovais

43. Folhas com margem crenada, serreada ou denticulada

44. Folhas peltadas

44'. Folhas não peltadas

45. Folhas reniformes de ápice arredondado

46. Pecíolo invaginante, bainha inteira, estípulas ausentes, pedúnculos opositifólios vários

9. Centella asiatica

46'. Pecíolo não invaginante, bainha ausente, par de estípulas na base do pecíolo, pedúnculo opositifólio solitário.

47. Folhas glabras, brácteas involucrais conadas entre

si .....................................................13. Hydrocotyle ranunculoides

47'. Folhas com tricomas nas nervuras principais, brácteas involucrais livres

12. Hydrocotyle leucocephala

45'. Folhas ovais de ápice lanceolado ou apiculado

48. Nervuras camptódromas, estípulas interpeciolares

126. Coccocypselum capitatum

48'. Nervuras acródromas, estípulas ausentes

43'. Folhas com margem inteira

49. Ramos hirsutos

80. Acisanthera variabilis

49'. Ramos glabros

50. Plantas eretas, flores dispostas em dicásios terminais ..... 70. Hypericum mutilum

50 '. Plantas rastejantes a ascendentes, flores solitárias, axilares

51. Face abaxial das folhas densamente glanduloso-pontuada, flores com pedicelo de $2,5-10 \mathrm{~mm}$ compr.

77. Lindernia rotundifolia

51'. Face abaxial das folhas não ou pouco glanduloso-pontuada, flores sésseis ou com pedicelos menores que $1 \mathrm{~mm}$ de compr. .....78. Micranthemum umbrosum

42'. Folhas lanceoladas, elípticas ou lineares

52. Folhas alternas

53. Plantas com folhas basais em rosetas

54. Plantas sem látex, folhas coriáceas, as basais amplexicaules, tricomas nas margens, nervura central verde na face adaxial

129. Nicotiana longiflora

54 '. Plantas com látex, folhas não coriáceas, nem amplexicaules, glabras, nervura central avermelhada na face adaxial

53'. Plantas com folhas não dispostas em roseta

55. Plantas com estípulas

56. Folhas com margem crenada a serreada

57. Erva, ramos avermelhados, glabra, estípulas conspícuas de margem laciniadas

84. Sauvagesia erecta

57'. Arbusto, ramos esverdeados, esparsamente pubescente, estípulas inconspícuas sem margem laciniadas

132. Boehmeria cylindrica 
Levantamento de plantas aquáticas e palustres na represa Guarapiranga, São Paulo

56'. Folhas com margem inteira

58. Estípulas transformadas em ócreas ................ Chave em Polygonaceae - pg. 52

58'. Estípulas não transformadas em ócrea ............... Chave em Onagraceae - pg. 43

55'. Plantas sem estípulas

59. Lâminas foliares com base assimétrica, truncada, face adaxial bulada 29. Heliotropium elongatum

59'. Lâminas foliares com base simétrica, não truncada, planas

60. Arbustos ou subarbustos maiores que $50 \mathrm{~cm}$ de alt.

61. Caule alado

61'. Caule não alado

62. Folhas com mais de $20 \mathrm{~cm}$ de compr.x $8 \mathrm{~cm}$ de larg.

23. Pluchea sagittalis

62 . Folhas de 4-12cm de compr. x 0,5-6cm de larg.

63. Lâminas foliares com base subcordada, ápice longamente acuminado, margem inteira a repanda

...33. Ipomoea carnea

63'. Lâminas foliares com base aguda a atenuada, ápice agudo a atenuado, margem denteada a serreada

64. Folhas alternas espiraladas, escabras ..... 19. Conyza canadensis

64'. Folhas alternas não espiraladas, glabras ou não escabras

65. Folhas trinervadas, aquênio com

papilho

18. Baccharis vulneraria

65 '. Folhas pinadas, aquênio sem papilho. 22. Ethulia conyzoides

60'. Ervas menores que $50 \mathrm{~cm}$ alt.

66. Lâminas ovais, papilosas, caule arroxeado nos ramos mais novos, fruto cápsula circuncisa ............................................. 124. Lysimachia minima

66'. Lâminas elípticas a oblongo-elípticas ou lanceoladas, não papilosas, caule verde a castanho, fruto esquizocarpo

67. Lâminas foliares glabras a pubérulas, flores solitárias, supraaxilares

27. Euploca lagoensis

67'. Lâminas foliares seríceas a estrigosas, flores dispostas em inflorescência escorpióide, terminal ou axilar

68. Folhas com nervação broquidódroma, ramos e folhas verde-cinéreos, inflorescência sem brácteas ........................28. Euploca procumbens

68'. Folhas com nervação hifódroma, ramos e folhas verde-escuros, inflorescência com brácteas lineares

52 '. Folhas opostas ou verticiladas

69. Folhas verticiladas (às vezes somente na parte basal)

70. Subarbustos, lâmina elíptica ou ovada, estípula interpeciolar presente

125. Borreria capitata

70'. Ervas, lâmina linear, estípula ausente

71. Plantas aquáticas submersas, folhas membranáceas, não rugosas, margem serrilhada 67. Egeria densa

71'. Plantas palustres prostradas, folhas crassas, rugosas, margem inteira

98. Nuttallanthus canadensis

69'. Folhas opostas

72. Plantas com estípulas interpeciolares

73. Ramos menores que $1 \mathrm{~mm}$ diâm, lâmina foliar de até $9 \mathrm{~mm}$ compr., bainha estipular de 0,1-0,2mm compr.

128. Oldenlandia salzmanii

73'. Ramos maiores que $3 \mathrm{~mm}$ de diâm., lâmina foliar maior que $20 \mathrm{~mm}$ de compr., bainha estipular de 4-8mm de compr.

127. Diodia saponariifolia

72'. Plantas sem estípulas

74. Plantas com tricomas glandulares

75. Erva de até $30 \mathrm{~cm}$ de alt.

75 '. Subarbusto ou arbusto, maiores que $30 \mathrm{~cm}$ de alt.

76. Lâmina foliar de margem serreada, nervação das folhas acródroma

81. Tibouchina herbacea

76'. Lâmina foliar de margem inteira e nervação das folhas camptódroma

74'. Plantas sem tricomas glandulares

77. Plantas rastejantes, com menos de $10 \mathrm{~cm}$ de alt.

78. Lâminas obovais maiores que $10 \mathrm{~mm}$ compr. presentes principalmente na base da planta, plantas pilosas

95. Mazus pumilus

78'. Lâminas elípticas menores ou iguais a $10 \mathrm{~mm}$ compr. presentes da base ao ápice do ramo, plantas glabras .99. Mecardonia procumbens

77 '. Plantas eretas ou suberetas maiores que $10 \mathrm{~cm}$ alt.

79. Lâminas com menos de $0,3 \mathrm{~cm}$ larg., geralmente subrevoluta

80. Lâminas elípticas, com glândulas diminutas na face abaxial, nervação eucamptódroma

69. Hypericum brasiliense

80'. Lâminas lineares, sem glândulas, nervação

hifódroma

94. Agalinis communis 
79'. Lâminas com mais de $0,3 \mathrm{~cm}$ de larg., margem plana

81. Lâminas foliares glabras; ramos com superfície cerosa

82. Lâmina foliar com ápice arredondado e base truncada, com muitas glândulas escuras 21. Enydra anagallis

82'. Lâmina foliar com ápice e base agudos, sem glândulas ...............................8. Alternanthera philoxeroides

81'. Lâminas foliares com indumento, ramos com superfície não cerosa

83. Lâmina foliar oval, pubescente com margem crenada a serreada

84. Plantas eretas, inflorescência em corimbos terminais 15. Ageratum conyzoides

84'. Plantas prostradas, inflorescência em racemos axilares ...................................100. Veronica javanica

83'. Lâmina elíptica ou lanceolada, estrigosa a escabra com margem inteira a denteada

85. Lâmina trilobada ou subastada, margem irregularmente denteada ..............................24. Sphagneticola trilobata

85'. Lâmina não lobada nem hastada, margem inteira a denticulada 20. Eclipta prostrata

Tratamento das espécies

\section{HEPÁTICAS}

RICCIACEAE

Bibliografia: Pott \& Pott (2000), Pompêo et al. (2011a, 2011b).

1. Ricciocarpos natans (L.) Corda, Naturalientausch 12: 651.1829

Fig.: $3 a$

Erva flutuante não enraizada, $0,5-1,0 \times 0,5-$ $1,5 \mathrm{~cm}$. Filódios bifurcados, face adaxial convexa, carnosa, verde brilhante, sulco longitudinal, negro quando fértil, margem crenada, face abaxial com rizóides de diferentes formatos e comprimentos, violáceos, esverdeados a castanhos. Distribuição cosmopolita. No Brasil ocorre em todas as regiões geográficas, atingindo Amazônia, Pantanal e Mata Atlântica. Esparsa a abundante em águas paradas ou pouco correntes, solos argilosos ou arenosos férteis. $\mathrm{Na}$ Represa Guarapiranga foi encontrada nos pontos PA2, PA3, PA4 e EM12 associada à Azolla filiculoides e Salvinia herzogii. Pode ser reconhecida facilmente pelos filódios flutuantes bifurcados com sulcos longitudinais.

Material examinado: Represa Guarapiranga, PA2, 29.IV.2009, M.E.F.Rodrigues 561 (ESA). Represa Guarapiranga, PA2, 19.II.2009, M.E.F.Rodrigues 552 (ESA).

\section{SAMAMBAIAS}

\section{OSMUNDACEAE}

Bibliografia: Tryon \& Tryon (1982), Sakagami (2006), Pompêo et al. (2011a, 2011b).

2. Osmunda regalis L., Sp. pl. 2: 1065-1066. 1753.

Fig.: $3 b$

Erva anfíbia, ereta, até $1,5 \mathrm{~m}$ alt. Caule horizontal. Frondes $30-150 \mathrm{~cm}$ compr., parcialmente dimorfas, lâmina estéril oblonga, 2-pinada; pinas alternas, 6-16×3-6cm; pínulas oval-lanceoladas, ápice obtuso ou arredondado, base subcordada, 0,8$2(3,4) \times 0,3-0,6(0,8) \mathrm{cm}$, alternas, pecioladas, margem denticulada, superfícies adaxial e abaxial glabras, nervuras livres, furcadas; lâmina fértil com pinas apicais férteis sem tecido laminar; pecíolo achatado, sulcado lateralmente, a base alargada, glabro e pinas basais iguais da lâmina estéril. Esporângios abundantes, grandes, globosos, ânulo lateral, verdepálido a castanho. Ampla distribuição nas zonas temperadas e tropicais. No Brasil ocorre desde Bahia e Centro-Oeste até o Sul, atingindo Cerrado e Mata Atlântica. Desenvolve-se bem em solos úmidos e alagados. Na Represa esteve presente apenas na área de brejo do banco EM12. Pode ser facilmente identificada pelas frondes dimorfas, sendo as pinas apicais férteis com numerosos esporângios verdes a castanhos e pinas basais estéreis.

Material examinado: Represa Guarapiranga, EM12, 8.VII.2008, M.E.F.Rodrigues 369 (ESA). 
Levantamento de plantas aquáticas e palustres na represa Guarapiranga, São Paulo

\section{SALVINIACEAE}

Bibliografia: Tryon \& Tryon (1982), Forno (1983), Pott \& Pott (2000).

Chave para as espécies

1. Folhas de superfície adaxial glabra, menores que $1 \mathrm{~mm}$ de compr., imbricadas parecidas com escamas ….................................. Azolla filiculoides

1'. Folhas de superfície adaxial pubescente, maiores que $1 \mathrm{~mm}$ de compr., não imbricadas

2. Tricomas com ápice livre ("pé-degalinha")

5. Salvinia minima

2'. Tricomas com ápice unido ("pá-de-batedeira")

3. Folha aberta, com muitos tricomas castanhos na face abaxial ........................ 6. Salvinia cf molesta

3'. Folha dobrada e erguida, sem tricomas na face abaxial

4. Salvinia herzogii

3. Azolla filiculoides Lam., Encycl. Méth. Bot. 1(1): 343. 1783.

Azolla caroliniana Willd., Sp. pl. 5(1): 541. 1810. Azolla microphylla Kaulf., Enum. Filic. 273. 1824. Fig.: $3 c$

Erva flutuante livre, até $1 \mathrm{~cm}$ compr., muitas raízes, ramificação pseudo-dicotômica. Frondes sésseis, bilobadas, dísticas, imbricadas, menores que $0,5 \mathrm{~mm}$ compr., cobrindo o rizoma, lobo superior flutuante, glauco a avermelhado, lobo inferior, hialino, submerso, entre os dois lobos formam-se câmaras onde as cianobactérias se fixam. Esporocarpos não vistos. Amplamente distribuída no mundo. Ocorrência em todas as regiões do Brasil atingindo Amazônia, Caatinga, Cerrado e Mata Atlântica. Apresenta crescimento bom em coluna de água doce de até $5 \mathrm{~cm}$ com pouca ou nenhuma movimentação. Na represa Guarapiranga foi raramente encontrada nos pontos PA1 e PA2. Facilmente identificada pelo porte e frondes imbricadas.

Material examinado: Represa Guarapiranga, PA1, 4.XII.2008, M.E.F.Rodrigues 524 (ESA, SP). Represa Guarapiranga, PA2, 29.V.2008, M.E.F.Rodrigues 347 (ESA, $\mathrm{SP})$.

4. Salvinia herzogii de la Sota, Darwiniana 12 : 514, f. 1-3. 1962.

Salvínia, orelha-de-rato.

Fig.: 3d

Erva flutuante livre, até $20 \mathrm{~cm}$ compr., rizomas flutuantes horizontais, sem raízes verdadeiras. Folhas em verticilos de três, sendo duas flutuantes ovais, fotossintéticas, de $2,2 \times 2,0 \mathrm{~cm}$, longitudinalmente dobradas, face adaxial pubescente, tricomas com o ápice divididos em quatro partes que se unem na extremidade; e uma folha submersa dividida em segmentos castanhos, semelhante a raízes que partem de um mesmo ponto. Esporocarpos subsésseis, aglomerados em um eixo compacto. Distribuição na América do Sul, Uruguai, Argentina e Paraguai. No Brasil possui presença no Sudeste e Sul. Comum em águas paradas. Espécie amplamente distribuída na Represa Guarapiranga, sendo encontrada em todos os pontos em mais de um período. Diferencia-se através do eixo fértil compacto com esporocarpos aglomerados e por possuir um padrão de aréolas primárias alongadas, sendo o lado maior cerca de seis vezes o comprimento do lado menor e aréolas secundárias de tamanhos e distribuição regulares. Segundo Zuloaga et al. (2008) este nome é sinônimo de $S$. biloba, porém Forno (1983) e Tryon \& Tryon (1982) apresentam como duas espécies diferentes.

Material examinado: Represa Guarapiranga, EG16, 2.IX.2008, M.E.F.Rodrigues 406 (ESA). Represa Billings, 2B, 15.V.2007, M.E.F.Rodrigues 200 (ESA, SP). Represa Guarapiranga, PA2 e PA3, 16.X.2008, M.E.F.Rodrigues 419 (ESA, SP). Represa Guarapiranga, EG17, 10.VI.2010, M.E.F.Rodrigues 568 (ESA).

5. Salvinia minima Baker, J. Bot. British and Foreign 24: 98. 1886.

Salvínia, orelha-de-rato.

Fig.: $3 e$

Erva flutuante livre, até $8 \mathrm{~cm}$ compr., rizomas flutuantes horizontais, sem raízes verdadeiras. Folhas em verticilos de três, sendo duas flutuantes arredondadas, fotossintéticas, de $1,2 \times 0,6 \mathrm{~cm}$, face adaxial pubescente, o ápice dos tricomas divididos em quatro partes que não se unem na extremidade; e uma folha submersa semelhante a raízes, pilosas castanho-brilhosas, divididas em segmentos que partem de um mesmo ponto. Esporocarpos ca. $1 \mathrm{~mm}$ diâm., subsésseis, dispostos ao longo de um eixo. Nativa, endêmica do Brasil. Amplamente distribuída nas Américas e no Brasil atingindo Amazônia, Cerrado, Pantanal e Mata Atlântica. Na Represa Guarapiranga foi coletada nos pontos PA4 e CC6, ocorrendo junto com Salvinia herzogii. Diferencia-se através dos tricomas não unidos no ápice e do porte claramente menor que as outras espécies do gênero.

Material examinado: Represa Guarapiranga, PA4, 3.IX.2008, M.E.F.Rodrigues 000415a (ESA, SP)

6. Salvinia cf. molesta D.S. Mitch., Brit. Fern Gaz. 10(5): 251-252. 1972.

Salvínia, orelha-de-rato.

Fig.: $3 f$

Erva flutuante livre, chegam até $20 \mathrm{~cm}$ compr., rizomas flutuantes horizontais, sem raízes verdadeiras. Folhas em verticilos de três, sendo duas flutuantes cordadas, fotossintéticas, de $2,2 \times 2,0 \mathrm{~cm}$, 

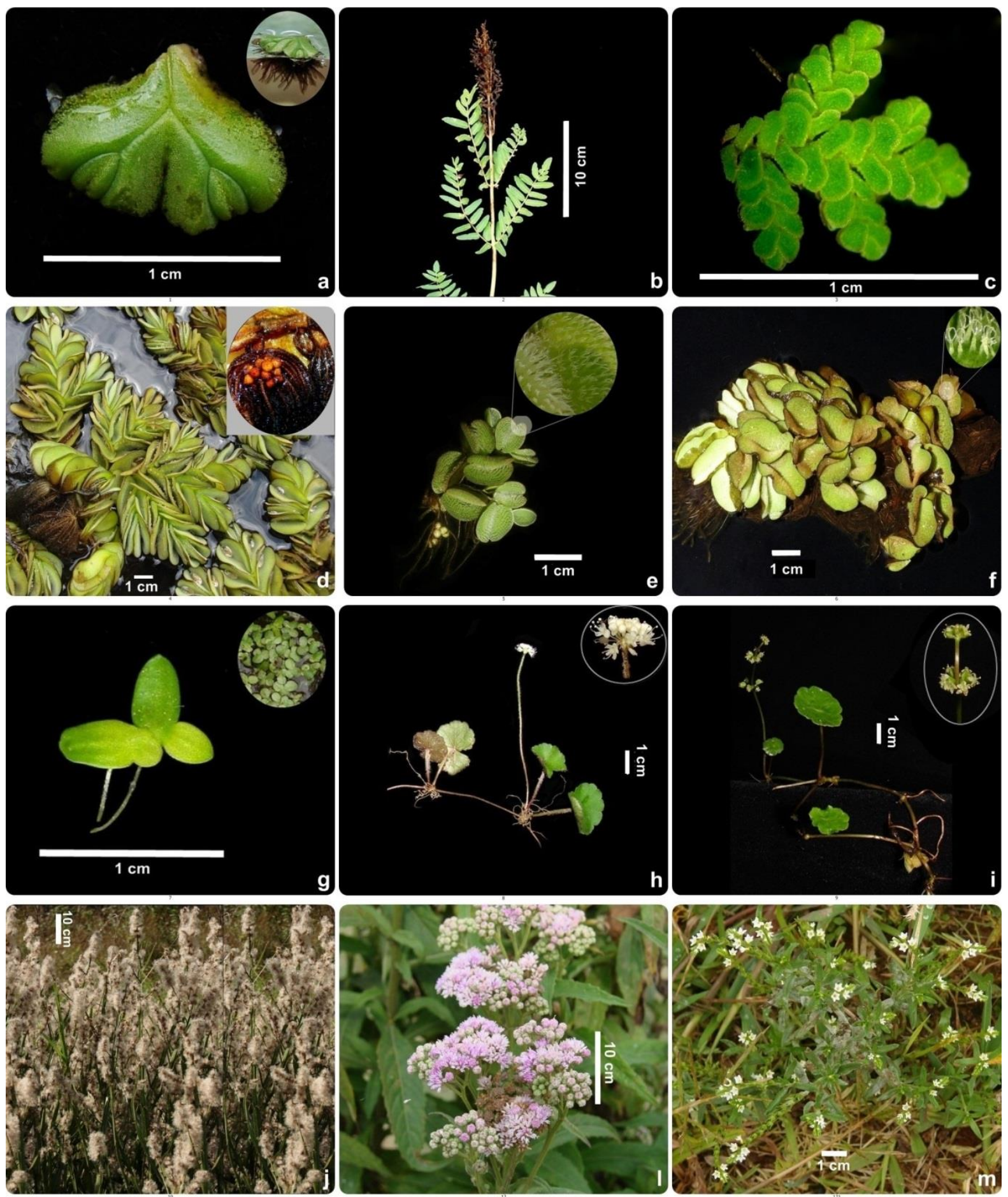

Fig. 3: Plantas aquáticas e palustres presentes na Represa Guarapiranga e não referidas em Amaral et al. (2008). a) Ricciocarpos natans; b) Osmunda regalis; c) Azolla filiculoides; d) Salvinia herzogii e) Salvinia minima; f) Salvinia cf molesta; g) Lemna aequinoctialis; h) Hydrocotyle leucocephala; i) Hydrocotyle verticillata; j) Baccharis crispa; I) Ethulia conyzoides; m) Euploca filiformis. 
Levantamento de plantas aquáticas e palustres na represa Guarapiranga, São Paulo

abertas longitudinalmente, ambas as faces pubescentes, tendo a face adaxial tricomas com o ápice dividido em quatro partes que se unem na extremidade e face abaxial com tricomas simples castanho brilhantes; e uma folha submersa dividida em segmentos castanhos, semelhante a raízes que partem de um mesmo ponto. Espécimes coletados sem esporocarpos. Distribuição na América do Sul: Uruguai, Argentina, Brasil e Paraguai. Segundo Zuloaga et al. (2008) este nome é sinônimo de $S$. adnata, a qual é referida em Salino \& Almeida (2016) no Sudeste e Sul do Brasil atingindo apenas a Mata Atlântica. Espécie encontrada em quatro pontos da Represa Guarapiranga (EG16, EG17, EG18 e EG19) com baixa abundância. Diferencia-se das outras espécies deste gênero encontradas na represa através da folha flutuante longitudinalmente aberta, face abaxial pubescente, tricomas castanhos e padrão de aréolas com o lado maior cerca de três vezes o comprimento do lado menor e aréolas secundárias de tamanhos e distribuição irregulares.

\section{Material examinado: Represa Guarapiranga, GUA3, 14.VI.2007, M.E.F.Rodrigues 197 (ESA). Represa Guarapiranga, EG17, 10.VI.2010, M.E.F.Rodrigues 567 (ESA).}

\section{ANGIOSPERMAS}

\section{ALISMATACEAE}

Bibliografia: Pott \& Pott (2000), Pansarin \& Amaral (2005), Amaral et al. (2008).

7. Sagittaria montevidensis Cham. \& Schltdl., Linnaea 2: 156. 1827.

Chapéu-de-couro.

Erva emergente, ereta, de $20-200 \mathrm{~cm}$, glabra. Folhas emersas, pecíolo cilíndrico até $50 \mathrm{~cm}$ compr., lâmina $18-44 \times 7-27 \mathrm{~cm}$, hastada a sagitada, nervação paralelódroma, 17-19 nervuras. Inflorescência em racemo, 3 flores por verticilo, brácteas unidas na base. Flores unissexuais, actinomorfas, pétalas brancas com manchas purpúreas na base, pedicelo recurvado e cilíndrico nas flores femininas, flores masculinas polistêmones. Aquênio com pedicelo reflexo e clavado. Distribuição do Equador e Peru, até Uruguai e norte do Chile. No Brasil ocorrem no Norte (AC), Centro-Oeste (MT), Sudeste (SP e RJ) e Sul (PR, RS e SC) atingindo Amazônia, Cerrado e Mata Atlântica. Cresce em água estagnada e poluída, sendo indicadora de ambiente antropizado e água eutrofizada. Na Represa Guarapiranga foi encontrada frequentemente nos pontos PA2, IT9 e EM14 e apenas uma vez nos pontos EG16 e EG17. Pode ser reconhecida pelas folhas emersas sagitadas e pelas manchas purpúreas na base das pétalas. Segundo Pansarin \& Amaral (2005) em São Paulo só ocorre a subsp. montevidensis, caracterizada pela presença de brácteas unidas e ausência de pistilódios nas flores masculinas, porém Matias et al. (2016) não referiu esta subespécie para o estado de São Paulo.

Material examinado: Represa Guarapiranga, GUA4, 9.XI.2007, M.E.F.Rodrigues 306 (ESA). Represa Guarapiranga, IT9, 29.V.2008, M.E.F.Rodrigues 344 (ESA). Represa Guarapiranga, EM14, 29.V.2008, M.E.F.Rodrigues 348 (ESA). Represa Guarapiranga, EM14, 2.IX.2008, M.E.F.Rodrigues 402 (ESA).

\section{AMARANTHACEAE}

Bibliografia: Pott \& Pott (2000), Siqueira (2002), Amaral et al. (2008).

8. Alternanthera philoxeroides (Mart.) Griseb., Abh. Königl. Ges. Wiss. Göttingen 24: 36. 1879.

Bredo d'agua, tripa-de-sapo, perpétua, erva-dejacaré, pé-de-pompa.

Erva emergente, $50 \mathrm{~cm}$ alt., semi-prostrada, ramos fistulosos, nós glabros ou pilosos. Folhas opostas cruzadas, base decorrente e pecíolo curto, 0,3-1cm compr., elípticas, ápice e base agudos, 2,6$12 \times 1,1-2,5 \mathrm{~cm}$. Inflorescência capituliforme, pedunculada, terminal ou axilar. Flores com 5 tépalas escariosas alvas, glabras, estames 3 , unidos em um tubo estaminal, pseudoestaminódios denteados alternando com os estames. Fruto indeiscente. Ampla distribuição na América do Sul. Amplamente distribuída no Brasil ocorrência em todas regiões geográficas, atingindo todos os biomas brasileiros. Possui potencial na despoluição de ambientes aquáticos, ocorrendo preferencialmente em água alcalina e rica em nutrientes. Na Represa Guarapiranga foi encontrada apenas uma vez nos pontos CC6 e IT9.

Material examinado: Represa Billings, F, 13.IV.2005, M.E.F.Rodrigues 26 (ESA). Represa Billings, J, 20.IV.2005, M.E.F.Rodrigues 33 (ESA). Represa Billings, K, 20.IV.2005, M.E.F.Rodrigues 34 (ESA). Represa Guarapiranga, 5G, 19.I.2007, M.E.F.Rodrigues 87 (ESA). Represa Guarapiranga, GUA2, 3.V.2007, M.E.F.Rodrigues 121 (ESA). Represa Guarapiranga, IT9, 5.XI.2008, M.E.F.Rodrigues 439 (ESA).

\section{APIACEAE}

Bibliografia: Corrêa \& Pirani (2005), Amaral et al. (2008).

9. Centella asiatica (L.) Urb. in Mart., FI. bras. 11(1): 287. 1879.

Pé-de-cavalo, patinha-de-vaca.

Erva emergente, estolonífera, $10,5 \mathrm{~cm}$ alt., caule delgado, glabro. Folhas simples, em roseta, sem 
estípula, longo pecioladas, 7,8cm compr., piloso, lâmina, 2,8×2,9cm, membranácea, face adaxial glabra e abaxial levemente hirsuta, reniforme a oval, não peltada, base cordada a truncada, margem crenada a denticulada. Inflorescência em umbelas axilares, 2-4 flores, pedúnculo curto, $0,8-1 \mathrm{~cm}$ compr. Flores 5meras inconspícuas, ca. $1 \mathrm{~mm}$ diâm., róseas. Fruto achatado, 2 mericarpos, ca. $1 \mathrm{~mm}$ diâm. Erva ruderal de origem asiática e africana, vastamente distribuída pelo mundo, no Brasil ocorre da Bahia à região Sul, atingindo Caatinga, Cerrado e Mata Atlântica. Desenvolve-se bem em lugares úmidos e tolera sombreamento, floresce de setembro a maio, frutificando em seguida. Na Represa Guarapiranga foi encontrada somente uma vez no ponto EG17. Identificada pela lâmina reniforme a oval, base truncada e margem denticulada.

Material examinado: Represa Guarapiranga, EG17, 4.XII.2008, M.E.F.Rodrigues 564 (ESA).

\section{ARACEAE}

Bibliografia: Kissmann \& Groth (2000), Pott \& Pott (2000), Pott (2002a), Amaral et al. (2008).

\section{Chave para espécies}

1. Frondes (folhas) até $0,3 \mathrm{~cm}$ compr., solitárias ou em grupos de 2-4, glabras, apenas uma raiz em cada fronde ...................................10. Lemna aequinoctialis

1'. Frondes de $10-15 \mathrm{~cm}$ compr., em rosetas, híspidas, com muitas raízes 11. Pistia stratiotes

10. Lemna aequinoctialis Welw., Apont. 578. 1858 [1859]. (Dec 1859).

Lentilha d'água.

Fig.: $3 g$

Erva flutuante livre, $0,3 \mathrm{~cm}$ diâm. Frondes solitárias ou em grupos de 2-4, lâmina 0,1-0,2cm compr., glabra, assimétrica, elíptica, três nervuras (vistas em folha clarificada), uma raiz por fronde, 1,0$1,5 \mathrm{~cm}$. Material examinado não possui flores nem frutos. Distribuição cosmopolita. No Brasil ocorre no Norte (AM), Nordeste (PI, CE, RN, PE, BA, AL), Centro-oeste (MT e MS), Sudeste (ES e RJ) e Sul (SC), atingindo Amazônia, Caatinga, Pantanal e Mata Atlântica. Segundo Coelho (2016), na flora do Brasil esta espécie não está presente no estado de São Paulo, porém a espécie é referida na Flora de São Paulo (Pott 2002). Desenvolve-se bem em locais mais protegidos de ambientes lênticos e áreas com influência antrópica, assim como em canais e canaletas de drenagem, sendo indicadora de água eutrofizada e eficiente na despoluição delas. $\mathrm{Na}$
Represa Guarapiranga foi encontrada frequentemente nos pontos PA1 ao PA4, CC8, IT9, IT11 ao EM14 e raramente nos pontos RB5, CC6, IT10 e EG15. Facilmente identificada através do porte diminuto, constituída apenas por fronde flutuante e raíz.

Material examinado: Represa Guarapiranga, PA2, 29.V.2008, M.E.F.Rodrigues 353 (ESA). Represa Guarapiranga, Parelheiros, s.l, s.d., M.E.F.Rodrigues 562 (ESA).

11. Pistia stratiotes L., Sp. pl. 2: 963. 1753.

Alface d'água.

Erva flutuante livre, $10-15 \mathrm{~cm}$ diâm., estolonífera. Frondes simples, em roseta, séssil a subséssil, lâmina $9 \times 6 \mathrm{~cm}$, esponjosa, híspida, obovada, nervuras evidentes. Inflorescência com espata branca e pilosa externamente, 2 flores unissexuadas, a masculina no ápice e feminina na base. Distribuição cosmopolita tropical e subtropical. Ocorre em quase todo território brasileiro, atingindo Amazônia, Caatinga, Cerrado, Pantanal e Mata Atlântica. Vive em água doce, corrente ou parada, desenvolve-se bem em águas eutrofizadas. Na Represa Guarapiranga esteve presente na maioria dos pontos com exceção dos EG16 ao EG19 durante o período de estiagem. Facilmente identificada pela semelhança com alface, mas com folhas carnosas e esponjosas.

Material examinado: Represa Billings, A, 13.IV.2005, M.E.F.Rodrigues 2 (ESA). Represa Billings, T, 11.V.2005, M.E.F.Rodrigues 52 (ESA).

\section{ARALIACEAE}

Bibliografia: Pott \& Pott (2000), Corrêa \& Pirani (2005), Amaral et al. (2008), Bove \& Paz (2009).

\section{Chave para as espécies}

1. Folhas peltadas 14. Hydrocotyle verticillata

1 '. Folhas não peltadas

2. Pecíolo 1-12cm compr., pedúnculo 0,3-1cm, menor que o pecíolo ......................13. Hydrocotyle ranunculoides

2'. Pecíolo $3-15 \mathrm{~cm}$ compr., pedúnculo $8-20 \mathrm{~cm}$, maior que o pecíolo ......................... 12. Hydrocotyle leucocephala

12. Hydrocotyle leucocephala Cham. \& Schltdl., Linnaea 1: 364. 1826.

Violinha, acariçoba-miúda.

Fig.: $3 \mathrm{~h}$

Erva anfíbia, prostrada, pilosa, estolão glabro. Folhas simples, alternas, pecioladas, $3-15 \mathrm{~cm}$ compr., glabro a hirsuto, lâmina $1,5-3,7 \times 2-4,6 \mathrm{~cm}$, paleácea, 
pilosa, tricomas nas nervuras principais, orbicular a reniforme, lobos obtusos suborbiculares, nervuras violáceas na face abaxial, brácteas involucrais livres. Inflorescência em umbela, 14-20 flores, ereta, pedúnculo $8-20 \mathrm{~cm}$ compr., maior que pecíolo. Flores brancas, $0,2 \times 0,1 \mathrm{~cm}$, pediceladas, pétalas ovais. Fruto, glabro, branco, estilete longo, maior que metade do comprimento do fruto. Distribuição do México até a Argentina. No Brasil é encontrado no Nordeste (CE, PB e BA), Centro-oeste (MT) Sudeste e Sul, atingindo o Cerrado e Mata Atlântica. Desenvolve-se bem em terrenos alagadiços, próximo à riachos ou cachoeiras no interior de matas, em margens de represas, interior de trilhas, beiras de estradas ou como invasora de jardim, preferencialmente em lugares sombrios. $\mathrm{Na}$ Represa Guarapiranga foi encontrada somente uma vez no ponto EG17. Diferencia-se pelas folhas reniformes com lobos obtusos e nervuras principais violáceas e pilosas.

Material examinado: Represa Guarapiranga, EG17, 4.XII.2008, M.E.F.Rodrigues 492 (ESA).

13. Hydrocotyle ranunculoides L. f., Suppl. PI. 177. 1781.

Cairuçu-do-brejo.

Erva emergente ou flutuante livre, prostrada, glabra. Folhas simples, alternas, pecioladas, $1-12 \mathrm{~cm}$ compr., lâmina 0,4-17,4×0,8-19,5cm, paleácea, glabra, oval a reniforme, margem crenada, brácteas involucrais conatas entre si. Inflorescência em umbela, 4-12 flores, pedúnculo menor que o pecíolo, $0,3-1 \mathrm{~cm}$ compr. Flores alvas, subsésseis a curtamente pediceladas, pétalas ovais. Fruto $0,2 \times 0,3 \mathrm{~cm}$, verde, glabro, reniforme. Distribuição do Sul dos Estados Unidos e México até Chile e Argentina. No Brasil ocorre da Bahia a região Sul, atingindo apenas a Mata Atlântica. Geralmente localizada em margens alagadas de rios e regatos, lagoinhas, águas lentas, campos úmidos e pântanos. $\mathrm{Na}$ Represa Guarapiranga esteve presente frequentemente nos pontos PA1, PA2, RB5 e EM13 e raramente nos pontos PA3, PA4, CC8 e EG16. Pode ser prontamente reconhecida pelas folhas reniformes e glabras.

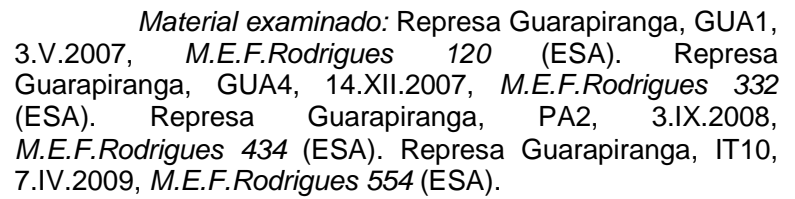

14. Hydrocotyle verticilatta Thunb., Hydrocotyle 2, 5-6, pl. s.n.[2]. 1798.

Fig.: 3i

Erva anfíbia, prostrada, glabra. Folhas simples, alternas, pecioladas, $1,5-11 \mathrm{~cm}$ compr., lâmina, 0,8-2,7cm diâm., membranácea, glabra, peltada, orbicular, margem crenada. Inflorescência espiciforme, 1-5 verticilos paucifloros, pedúnculo 2$8,5 \mathrm{~cm}$ compr. Flores brancas, sésseis a pediceladas, pétalas triangular-lanceoladas. Fruto verde, glabro, orbicular, base truncada. Distribuição do norte dos Estados Unidos ao sul do Chile. No Brasil ocorre no Centro-Oeste (MS), Sudeste e Sul, atingindo apenas a Mata Atlântica. Localizada em margens de rios, próximo a lagoas ou represas, ou em solos úmidos ou lodosos, ricos em matéria orgânica, preferencialmente em lugares sombreados. Na Represa Guarapiranga foi encontrada somente nos pontos PA2 e EM12. Diferencia-se das outras espécies de Hydrocotyle da represa pela folha peltada, orbicular e glabra.

Material examinado: Represa Guarapiranga, GUA4, 14.XII.2007, M.E.F.Rodrigues 333 (ESA). Represa Guarapiranga, EM12, 16.X.2008, M.E.F.Rodrigues 420 (ESA). Represa Guarapiranga, EM12, 16.X.2008, M.E.F.Rodrigues 429 (ESA). Represa Guarapiranga, PA2, 4.XII.2008, M.E.F.Rodrigues 518 (ESA). Represa Guarapiranga, PA2, 3.IX.2008, M.E.F.Rodrigues 000415b (ESA).

\section{ASTERACEAE}

Bibliografia: Barroso (1991), Kissmann \& Groth (2000), Lorenzi (2000), Pott \& Pott (2000), Amaral et al. (2008)

\section{Chave para as espécies}

1. Plantas com folhas inconspícuas e ramos trialados ........................................ 17. Baccharis crispa

1'. Plantas com folhas conspícuas e caule não trialado

2. Folhas pinatífidas .................16. Ambrosia artemisiifolia

2'. Folhas inteiras

3. Folhas alternas

4. Caule alado pela base das folhas decorrentes ......................... 23. Pluchea sagittalis

4'. Caule não alado e folhas não decorrentes

5. Folhas alternas espiraladas e lâminas escabras .......................19. Conyza canadensis

5'. Folhas alternas não espiraladas e lâminas glabras ou não escabras

6. Folhas trinervadas; aquênio com papilho .................... 18. Baccharis vulneraria

6'. Folhas peninérveas; aquênio sem papilho ….....................22. Ethulia conyzoides

3'. Folhas opostas

7. Lâminas foliares cartáceas e glabras ...............................21. Enydra anagallis

7'. Lâminas foliares não cartáceas com indumentos

8. Lâmina oval e margem crenada ...................... 15. Ageratum conyzoides

8'. Lâmina elíptica ou lanceolada, margem inteira ou denteada

9. Lâmina trilobada ou subastada, margem irregularmente denteada ...............24. Sphagneticola trilobata

9'. Lâmina não lobada nem hastada, margem inteira a denticulada ..........20. Eclipta prostrata 
15. Ageratum conyzoides L., Sp. pl. 2: 839. 1753. Picão-roxo, catinga-de-bode.

Erva anfíbia, ereta, até $60 \mathrm{~cm}$ alt., ramos pilosos. Folhas simples, opostas na base e alternas no ápice, pecíolo 0,5-2,5(4)cm, lâmina 2,5-6,0x1,5-4,5cm, oval, pilosa, margem crenada. Corimbos terminais e axilares, 4-20 capítulos cada um. Capítulos ovalados, $5-7 \mathrm{~mm}$ alt., diversas séries de filárias involucrais, de comprimento equivalente. Aquênio com papilho formado por cinco páleas triangulares muito agudas. Distribuição pantropical. Está distribuída em quase todo o Brasil, atingindo todos os biomas brasileiros. Sobrevive em quase todos os tipos de solos preferindo, contudo, solos argilosos, em locais úmidos, tolerando ambientes relativamente secos. Na Represa Guarapiranga estiveram presentes nos pontos PA2, EM14 e IT11, locais considerados palustres.

Material examinado: Represa Guarapiranga, GUA6, 19.IX.2007, M.E.F.Rodrigues 223 (ESA). Represa Guarapiranga, GUA4, 10.X.2007, M.E.F.Rodrigues 266 (ESA). Represa Guarapiranga, GUA1, 14.XII.2007, M.E.F.Rodrigues 315 (ESA). Represa Guarapiranga, EM14, 6.VIII.2008, M.E.F.Rodrigues 393 (ESA).

16. Ambrosia artemisiifolia L., Sp. pl. 2: 988. 1753. Losna-selvagem.

Erva anfíbia, ereta, $12-55 \mathrm{~cm}$ alt. Folhas pinatífidas, segmentos lanceolados ou ovadolanceolados, oposta na base e alterna no ápice do caule, lâmina de 1,5-8x1,5-6cm, pilosa. Racemos ou cachos curtos, capítulos de invólucro campanulado, verde-amarelado, flores masculinas de corola brancoamarelada, flores femininas sem corola agrupadas abaixo das inflorescências masculinas ou na parte terminal dos ramos. Aquênio incluso em invólucro rígido, piloso, rostro grosso circundado por uma coroa de 5-8 projeções. Planta nativa no Continente Americano, ocorrendo desde o Canadá até Argentina. Ocorre em grande parte do território brasileiro, atingindo a Amazônia e Mata Atlântica. Na Represa Guarapiranga foi encontrada frequentemente nas margens durante período de estiagem nos pontos PA1, PA2, CC6, IT9, EG15 e EG20. Identificada pelas folhas pinatífidas e pela inflorescência descrita acima.

Material examinado: Represa Guarapiranga, GUA5, 14.XII.2007, M.E.F.Rodrigues 318 (ESA). Represa Guarapiranga, IT9, 3.XII.2008, M.E.F.Rodrigues 463 (ESA). 1826.

17. Baccharis crispa Spreng., Syst. Veg. 3: 466.

Carqueja, carqueja-amargosa

Baccharis cylindrica (Less.) DC., Prodr. 5:426. 1836.

Baccharis myriocephala DC, Prodr. 5: 426. 1836.

Baccharis trimera (Less.) DC., Prodr. 5: 425., 1836. Fig. 3j

Subarbusto anfíbio, ereto, até $3 \mathrm{~m}$ alt., ramos com alas de $0,5-1,5 \mathrm{~cm}$ larg. Folhas inconspícuas, alternas, sésseis, lâminas de $0,7 \times 0,5 \mathrm{~cm}$, coriáceas, elípticas, glabras. Capítulos sésseis formando espigas terminais densas, com invólucros de até $5 \mathrm{~mm}$ diâm. Aquênios com papilho piloso e creme. Amplamente distribuída na América do Sul. No Brasil ocorre no Nordeste (CE, PE e BA), Centro-oeste (GO, DF e MS), no Sudeste e Sul, atingindo Caatinga, Cerrado, Mata Atlântica e Pampa. Desenvolve-se de forma mais exuberante em solos férteis e úmidos. Na Represa Guarapiranga foi observada com frequência somente no ponto EM12. Facilmente diferenciada das demais espécies da represa pelos ramos trialados.

Material examinado: Represa Guarapiranga, EM12, 8.VII.2008, M.E.F.Rodrigues 374 (ESA).

18. Baccharis vulneraria Baker in Mart., FI. bras. 6(3): 75.1882

Erva de sant'ana, erva-sant'ana.

Baccharidastrum triplinervium (Less.) Cabrera, Notas Mus. La Plata, Bot. 2(16): 177. 1937.

Arbusto anfíbio, ereto, até $1 \mathrm{~m}$ alt., caule e ramos estriados, glabros, avermelhados. Folhas simples, alternas, sésseis, lâmina, $4-8 \times 0,5-2,5 \mathrm{~cm}$, glabra, oblanceoladas, margem serreada, trinervada na base. Capítulos pedunculados brancos a cremes. Aquênio com papilho de cerdas finas e longas. Amplamente distribuída na América do Sul. No Brasil ocorre no Norte (RO), Centro-Oeste (MT, MS), Sudeste e Sul, atingindo Amazônia, Cerrado, Mata Atlântica e Pampa. Na Represa Guarapiranga esteve presente somente no ponto EM12. Facilmente diferenciada das demais espécies de Asteraceae da área pelas folhas trinervadas.

Material examinado: Represa Guarapiranga, EM12, 3.XII.2008, M.E.F.Rodrigues 479 (ESA).

19. Conyza canadensis (L.) Cronquist, Bull. Torrey Bot. Club 70(6): 632. 1943.

Buva-do-canadá, buva, voadeira.

Fig.: 31

Subarbusto emergente, ereto, 0,55-1,0m alt., Folhas simples, alterna espiralada, sésseis, lâmina 4$7 \times 0,5-1 \mathrm{~cm}$, escabras, lanceoladas, margens denteadas. Panícula ereta, terminal, muito ramificada, capítulos pedicelados, menores que $1 \mathrm{~cm}$ diâm., dourados. Aquênios com papilho amarelado. Distribuição frequente em regiões temperadas no Hemisfério Norte e subtropicais do Hemisfério Sul e pouco frequente em regiões equatoriais. No Brasil ocorre da Bahia à região Sul, atingindo a Caatinga, Cerrado, Mata Atlântica e Pampa. Na Represa Guarapiranga foi observada apenas no ponto IT10 durante quatro meses, emersa da água. Planta muito parecida com Conyza bonariensis diferencia-se por esta apresentar folhas com margens inteiras, capítulos maiores que $1 \mathrm{~cm}$ de diâm. 
Levantamento de plantas aquáticas e palustres na represa Guarapiranga, São Paulo

Material examinado: Represa Guarapiranga, IT10 3.XII.2008, M.E.F.Rodrigues 465 (ESA).

20. Eclipta prostrata (L.) L., Mant. pl. 2: 2861771. Erva-de-botão, agrião-do-brejo, pimenta d'água, tangaracá.

Eclipta alba (L.) Hassk., PI. Jav. Rar. 528.

Erva emergente, ereta ou prostrada, até $60 \mathrm{~cm}$ alt. Folha simples, oposta, séssil abraçando o caule (decorrente) na parte superior da planta e subséssil na parte inferior, lâmina, $4-5 \times 0,5-1 \mathrm{~cm}$, estrigosa, oblongo-lanceolada, margem inteira ou denticulada. Inflorescência em capítulos isolados ou pareados, axilares, pedúnculo, $0,5-5 \mathrm{~cm}$ compr. Capítulos subglobosos, 0,5-1,0cm diâm., invólucro verde campanulado a plano, muitos flósculos de corola branca. Aquênios castanhos, obovoide-comprimidos de superfície densamente rugoso-tuberculada, papilho reduzido a 2-3 projeções pretas. Distribuição cosmopolita. Ocorre em todo território brasileiro atingindo todos os biomas brasileiros. Esparsa em campos alagáveis, bordas de lagoas e corixos, brejos, e componente do baceiro, solos férteis, arenosos ou argilosos. $\mathrm{Na}$ Represa Guarapiranga raramente presente nos pontos PA1, PA2, IT9 e EM14. Identificada por seus capítulos característicos e aquênios com papilho reduzido.

\begin{abstract}
Material examinado: Represa Paiva Castro, 3P, 26.III.2007, M.E.F.Rodrigues 112 (ESA). Represa Guarapiranga, GUA5, 19.IX.2007, M.E.F.Rodrigues 221 (ESA). Represa Guarapiranga, Marina Silvester, 10.X.2007, M.E.F.Rodrigues 280 (ESA).
\end{abstract}

21. Enydra anagallis Gardner, London J. Bot. 7: 409. 1848.

Erva emergente ou anfíbia, prostrada, até $2 \mathrm{~m}$ alt., caules de superfície cerosa, fistulosos. Folhas simples, opostas cruzadas, séssil, lâmina, 2-3,5×0,5$1 \mathrm{~cm}$, cartácea, glabra, muitas glândulas escuras, ápice arredondado e base truncada, margem denteada principalmente no ápice. Capítulos sésseis, axilares, dois pares cruzados de brácteas, ovais, coloração verde-clara, flósculos brancos. Aquênios sem papilho. Distribuição na América do Sul. No Brasil ocorrem no Centro-Oeste (MS, MT), Sudeste (RJ, SP) e Sul, atingindo o Pantanal, a Mata Atlântica e Pampa. Presente geralmente sobre baceiro e camalotes, solos argilosos, siltosos ou orgânicos. $\mathrm{Na}$ Represa Guarapiranga foi encontrada com frequência nos pontos PA1 ao EM14 e EG20 e raramente nos pontos EG15 e EG16, não esteve presentes em nenhum período nos pontos EG17 ao EG19. Facilmente identificada pelas folhas e inflorescência.

Material examinado: Represa Billings, A, 13.IV.
2005, M.E.F.Rodrigues 5 (ESA). Represa Billings, B, 13.IV.2005, M.E.F.Rodrigues 11 (ESA). Represa Billings, D, 13.IV.2005, M.E.F.Rodrigues 20 (ESA). Represa Billings, V, 26.VIII.2005, M.E.F.Rodrigues 57 (ESA). Represa Billings, 1B, 29.XI.2006, M.E.F.Rodrigues 70 (ESA). Represa Billings, 2B, 29.XI.2006, M.E.F.Rodrigues 71 (ESA). Represa Guarapiranga, 1G, 19.I.2007 M.E.F.Rodrigues 81 (ESA). Represa Paiva Castro, 3P, 26.III.2007, M.E.F.Rodrigues 115 (ESA). Represa Guarapiranga, PA2, 3.IX.2008, M.E.F.Rodrigues 411 (ESA).

22. Ethulia conyzoides L.f., Dec. PI. Horti Upsal. 1, t. 1.1762.

Erva anfíbia, ereta, até $30 \mathrm{~cm}$ alt. Folhas simples, alternas, sésseis, lâmina, 4,5-9x0,7-1,3cm, glabra, lanceolada, ápice atenuado, margem serreada, peninérveas. Capítulos pedunculados, invólucro redondo com várias séries de brácteas, flores de até $1 \mathrm{~mm}$, pétalas rosadas. Aquênio piramidal, rugoso, brilhante, sem papilho. Distribuição na África, Ásia e Brasil. Embora não tenha sido referida por Nakajima et al. (2016), provavelmente por ser introduzida, a espécie ocorre no Sudeste do Brasil. Na Represa Guarapiranga esteve presente com frequência nos pontos PA2, PA4, RB5, CC6 e IT9.

Material examinado: Represa Guarapiranga, 7G, s.d., M.E.F.Rodrigues 94 (ESA). Represa Guarapiranga, GUA5, 19.IX.2007, M.E.F.Rodrigues 209 (ESA). Represa Guarapiranga, GUA6, 10.X.2007, M.E.F.Rodrigues 244 (ESA).

23. Pluchea sagittalis (Lam.) Cabrera, Bol. Soc. Argent. Bot.3(1): 36. 1949.

Erva anfíbia, ereta, até $1,2 \mathrm{~m}$ alt., caule e ramos alados. Folhas simples, alternas, sésseis, lâmina, 4-8,8 x1-3cm, membranácea, pilosa, tricomas glandulares em ambas as faces, lanceoladas a elíptico-lanceoladas, base decorrente, margens denteadas. Corimbos terminais vistosos, capítulos subglobosos numerosos, aveludados, branco a castanho, pedúnculos alados, flósculos periféricos mais longos e mais claros que os centrais. Aquênio com papilho piloso. Distribuição América do Sul. No Brasil ocorre no Norte (AP, PA e AC), Nordeste (MA, $\mathrm{PE}$, BA e SE), Centro-oeste (GO) e toda região Sudeste e Sul atingindo Amazônia, Caatinga, Cerrado, Mata Atlântica e Pampa. Ocupa áreas úmidas, sendo infestante de várzeas, inclusive em culturas de arroz. $\mathrm{Na}$ Represa Guarapiranga esteve presente próxima ao ponto EM12. Facilmente identificada pelo caule alado com folhas decorrentes e sua inflorescência muito característica.

Material examinado: Represa Billings, $\mathrm{H}$, 13.IV.2005, M.E.F.Rodrigues 32 (ESA). Represa Billings, M, 20.IV.2005, M.E.F.Rodrigues 41 (ESA). Represa Guarapiranga, 19.I.2007, M.E.F.Rodrigues 89 (ESA). 
24. Sphagneticola trilobata (L.) Pruski, Mem. New York Bot. Gard. 87: 114. 1996.

Wedelia paludosa DC., Prodr. 5: 538. 1836.

Margarida, Mal-me-quer-do-brejo.

Erva anfíbia, decumbente, até $2 \mathrm{~m}$ alt. Folhas simples, opostas, subsésseis, lâmina, 3-5,5x1-2,5cm, estrigosas, trilobada ou subastada, margem irregularmente denteada. Capítulos isolados, axilares, vistosos, pedúnculo de até $10 \mathrm{~cm}$, flósculos femininos com lígulas amarelas na periferia, flósculos bissexuais no centro com anteras castanho-escuras. Aquênio sem papilho. Distribuição América do Norte e do Sul. Ocorre em todo território brasileiro, atingindo todos os biomas brasileiros. Torna-se agressiva em áreas úmidas, mas desenvolve-se também em locais elevados não sujeitos a secas prolongadas. $\mathrm{Na}$ Represa Guarapiranga esteve presente nos pontos PA4, CC6, CC8, EM12, EM13, EM14, EG16, EG17. Identificada através da base atenuada da folha, dois lobos agudos perpendiculares ao eixo, ápice agudo e capítulos isolados com longos pedúnculos.

Material examinado: Represa Guarapiranga, GUA5, 19.IX.2007, M.E.F.Rodrigues 206 (ESA). Represa Guarapiranga, GUA6, 10.X.2007, M.E.F.Rodrigues 258 (ESA). Represa Guarapiranga, GUA6, 10.X.2007, M.E.F.Rodrigues 264 (ESA)

\section{BEGONIACEAE}

Bibliografia: Jacques (2002).

25. Begonia fischeri Schrank, PI. Rar. Hort. Monac. 2: t. 59. 1820.

Begônia.

Erva anfíbia, decumbente, $30 \mathrm{~cm}$ alt., ramos avermelhados, hirsutos, caule fistuloso. Folhas simples, alternas, pecíolos hirsutos, 0,5-5cm compr., estípulas, lâmina, 1,5-3,5×2,5-7cm, coriácea, pilosa na face adaxial e hirsutas na abaxial, assimétrica, margem sinuosa, 5-7 nervuras actinódromas. Inflorescências em tirsos, 2 flores unissexuadas, pedunculadas, masculinas com 4 tépalas e femininas com 5 tépalas. Cápsula trialada. Distribuição do México até Argentina. No Brasil ocorre no Norte (RR), Nordeste (PE e BA), Centro-oeste (MT, GO, DF e MS) e nas regiões Sudeste e Sul, atingindo Amazônia, Caatinga, Cerrado e Mata Atlântica. Desenvolve-se bem em locais com luminosidade intensa, em solos arenosos, argilosos, temporariamente ou permanentemente inundados, como pequenos córregos. Na Represa Guarapiranga foi encontrada apenas nos pontos, PA2, IT9 e EM12. Identificada pelas folhas discolores, assimétricas, com uma ala muito maior que outra tanto na folha quanto na cápsula.
Material examinado: Represa Guarapiranga, GUA4, 10.X.2007, M.E.F.Rodrigues 269 (ESA). Represa Guarapiranga, EM12, 8.VII.2008, M.E.F.Rodrigues 373 (ESA).

\section{BORAGINACEAE}

Bibliografia: Melo \& Semir (2008), Melo \& Semir (2009).

\section{Chave para as espécies}

1. Pecíolos semi alados e folhas buladas, não planas .................................... 29. Heliotropium elongatum 1'. Pecíolos não alados e folhas planas

2. Lâminas foliares glabras a pubérulas, flores solitárias, supra-axilares ............ 27. Euploca lagoensis

2'. Lâminas foliares seríceas a estrigosas, inflorescência escorpióide, terminal ou axilar

3. Nervação broquidódroma, ramos e folhas verdecinéreos, inflorescência sem brácteas ...........................28. Euploca procumbens

3'. Nervação hifódroma, ramos e folhas verde-escuros, inflorescência com brácteas filiformes 26. Euploca filiformis

26. Euploca filiformis (Lehm.) J.I.M.Melo \& Semir, Kew Bull. 64(2): 285. 2009.

Fig.: $3 \mathrm{~m}$

Erva anfíbia, ereta ou prostrada, $25 \mathrm{~cm}$ alt. Folhas simples, alternas, pecioladas; pecíolo 0,10,4cm compr., lâmina 0,5-2,1 $1 \times 0,1-0,4 \mathrm{~cm}$, membranácea, elíptica, lanceolada, oblanceolada ou, mais raramente, linear, serícea a estrigosa em ambas as faces, nervura proeminente, achatada; venação hifódroma. Inflorescência, terminal e lateral, séssil, brácteas filiformes a subuladas, opostas às flores. Flores 2,5-3mm, subsésseis; corola tubular branca com fauce amarela. Esquizocarpo com quatro núculas trigonas, seríceas. Distribuem-se desde o México, Antilhas alcançando Argentina. Ocorre em quase todo território brasileiro, exceto o Acre na região Norte, grande parte do Nordeste e a região Sul atingindo Amazônia, Cerrado, Mata Atlântica e Pantanal. Geralmente é encontrada próxima a cursos d'água e em áreas sujeitas a inundações periódicas, especialmente em leitos de rios e lagos na planície amazônica, depressão pantaneira, cerrado e em ecótono cerrado-campo rupestre, associada a solos arenosos, argilosos ou areno-argilosos. Na Represa Guarapiranga foi encontrada nos pontos PA2, RB5 e EM14. Identificada pelas flores brancas com fauce amarela em inflorescência escorpióide com brácteas filiformes a subuladas opostas às flores. 
Material examinado: Represa Guarapiranga, EG15, 4.XII.2008, M.E.F.Rodrigues 521 (ESA, UEP). Represa Guarapiranga, GUA4, 9.XI.2007, M.E.F.Rodrigues 298 (ESA) Represa Guarapiranga, GUA5, 9.XI.2007, M.E.F.Rodrigues 305 (ESA, UEP).

27. Euploca lagoensis (Warm.) Diane \& Hilger, Bot. Jahrb. Syst. 125(1): 48. 2003.

Fig.: $4 \mathrm{a}$

Erva anfíbia, decumbente ou prostrada. Folhas simples, alternas, pecioladas; pecíolo ca. $0,1 \mathrm{~cm} \quad$ compr., lâmina $0,5-0,9 \times 0,1-0,2 \mathrm{~cm}$, membranácea a subcarnosa, estreitamente elíptica a oblongo-elíptica, face adaxial glabra, face abaxial glabra a pubérula; venação hifódroma. Flores ca. $3 \mathrm{~mm}$ diâm., solitárias, supra-axilares, pediceladas; pedicelo ca. 0,5mm compr.; corola 3-4mm diâm., tubular, branca, fauce amarela. Esquizocarpo, piriforme, sulcado, rostrado; núculas trígonas e glabras. Distribui-se desde o México até o Brasil, no Norte (AM), Nordeste (CE, PB, PI, RN), Centro-oeste (GO e MS) e Sudeste (MG e SP), atingindo Amazônia, Caatinga e Cerrado. Geralmente encontrada em margens de rios e lagoas, leito seco de lagoas temporárias e áreas sujeitas a inundações periódicas. $\mathrm{Na}$ Represa Guarapiranga foi encontrada nos pontos RB5, CC6, EG15 e EG17. Identificada pelas flores brancas com fauce amarela, solitárias, supra-axilares.

Material examinado: Represa Guarapiranga, GUA5, 10.X.2007, M.E.F.Rodrigues 243 (ESA, UEP). Represa Guarapiranga, CC6, 16.X.2008, M.E.F.Rodrigues 432 (ESA). Represa Guarapiranga, EG17, 4.XII.2008, M.E.F.Rodrigues 495 (ESA, UEP).

28. Euploca procumbens (Mill.) Diane \& Hilger, Bot. Jahrb. Syst. 125(1): 48. 2003.

Erva anfíbia, ereta ou prostrada, $5-50 \mathrm{~cm}$ alt., ramos verde-cinéreos, indumento seríceo em ramos, folhas, flores e frutos. Folhas simples, alternas, pecioladas; pecíolo $0,4-2,4 \mathrm{~cm}$ compr., lâmina 1$7,5 \times 0,3-2,4 \mathrm{~cm}$, subcarnosa, estreitamente elíptica, elíptica a oblongo-elíptica, venação broquidódroma. Inflorescência escorpióide terminal e axilar, inteira ou bifurcada, sem brácteas; pedúnculo 0,9-3cm compr. Flores 1,6-2mm diâm., subsésseis; corola, tubular, branca, fauce amarela. Esquizocarpo subgloboso; núculas ca. $1 \mathrm{~mm}$ diâm., trígonas, seríceas a hirsutas. Ocorre do Sul dos Estados Unidos até Argentina. Amplamente distribuída no Brasil, atingindo todos os biomas brasileiros. Geralmente está associada a ambientes palustres, como orlas de rios, riachos, açudes, charcos, regatos e em orlas de matas ciliares, especialmente no complexo pantaneiro e cerrado, formando densas populações. $\mathrm{Na}$ Represa Guarapiranga foi encontrada somente no ponto CC7. Identificada pelas flores brancas com fauce amarela em inflorescência escorpióide sem brácteas e ramos verde-cinérios.
Material examinado: Represa Guarapiranga, CC6, 8.I.2009, M.E.F.Rodrigues 537 (ESA, UEP).

29. Heliotropium elongatum (Lehm.) I.M.Johnst., Contr. Gray Herb. 81: 18. 1928.

Fig.: 4b

Erva ou subarbusto anfíbia, subereto ou decumbente, $10-90 \mathrm{~cm}$ alt. Folhas alternas ou subopostas, pecioladas; pecíolo 0,6-5,7cm compr., parcialmente alado; lâmina 2-12,5x1,2-7,8cm, membranácea, escabra a glabrescente, ápice ovada, cordiforme a deltoide, base assimétrica, truncada, face adaxial bulada, venação eucamptódroma. Inflorescência subterminal e axilar; pedúnculo $2-4 \mathrm{~cm}$ compr. Flores 3-6,5mm, sésseis; cálice persistente no eixo da inflorescência após a queda do fruto, corola hipocrateriforme, alva a arroxeada. Fruto esquizocarpo. Restringe-se à América do Sul. Amplamente distribuída no Brasil, associada à Amazônia, Caatinga, Cerrado, Mata Atlântica e Pampa. Frequente em áreas agrícolas de solo úmido, margem de estradas e áreas desocupadas. $\mathrm{Na}$ Represa Guarapiranga foi encontrada nos pontos CC6 e IT9. Identificada pela lâmina foliar bulada e pecíolo semi-alado.

Material examinado: Represa Guarapiranga, GUA6, 10.X.2007, M.E.F.Rodrigues 251 (ESA).

\section{CAMPANULACEAE}

Bibliografia: Vieira (2003), Amaral et al., (2008).

30. Lobelia exaltata Pohl, PI. Bras. Icon. Descr. ii. 101. t. 166.

Lobélia.

Erva emergente, ereta, até $3 \mathrm{~m}$ alt., latescente, caule glabro. Folhas simples, alterna espiraladas, sésseis, dispostas na base do caule e decíduas na infrutescência, lâmina, 20-33×3-4cm, glabra, lanceolada, margem hialina serrilhada, nervuras de coloração púrpura. Inflorescência em racemo, densiflora, terminal, até $85 \mathrm{~cm}$ compr., bráctea linear, deflexa. Flores pediceladas, pentâmeras, corola alva a esverdeada, pilosa internamente na base. Fruto cápsula, sementes aladas. Planta endêmica do Brasil, ocorrendo somente no Sudeste (MG, SP) e Sul (PR, SC), associada apenas a Mata Atlântica. Pode ser encontrada em locais alagados, de solo turfoso, margens de curso d'água ou capoeiras. Na Represa Guarapiranga esteve presente somente no ponto EM12 próximo a uma área do Parque Ecológico Guarapiranga. Facilmente reconhecida pelo porte robusto, pelo racemo longo pedunculado e pelas folhas alternas espiraladas com nervuras púrpuras.

Material examinado: Represa Guarapiranga, EM12, 8.VII.2008, M.E.F.Rodrigues 371 (ESA). 

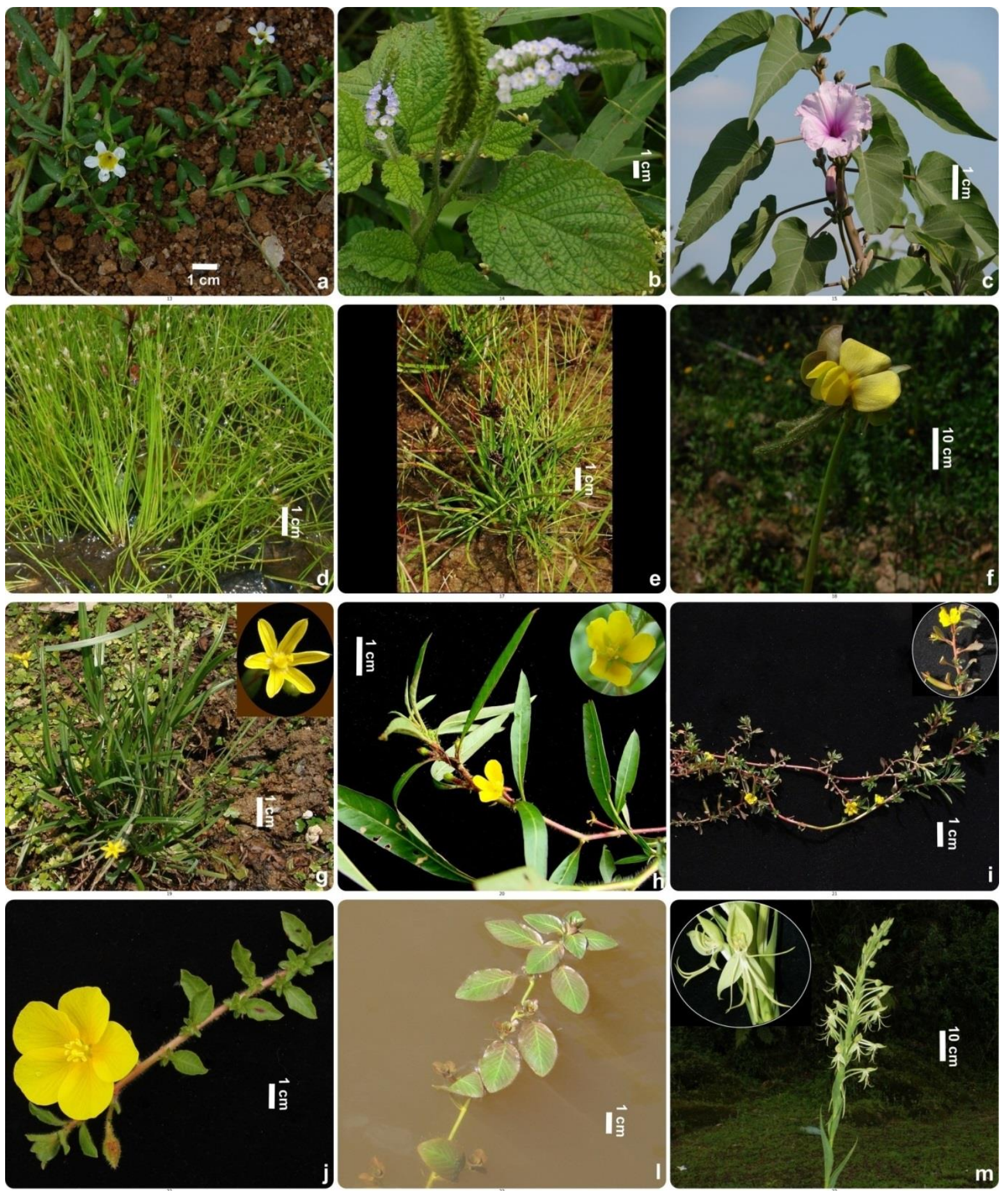

Fig. 4: Plantas aquáticas e palustres presentes na Represa Guarapiranga e não referidas em Amaral et al. (2008). a) Euploca lagoensis; b) Heliotropium elongatum; c) Ipomoea carnea; d) Eleocharis bonariensis; e) Rhynchospora riparia; f) Vigna luteola; g) Sisyrinchium commutatum; h) Ludwigia peploides subsp. montevidensis; i) Ludwigia peploides subsp. peploides; j) Ludwigia grandiflora; I) Ludwigia sp; m) Habenaria paulistana. 
Levantamento de plantas aquáticas e palustres na represa Guarapiranga, São Paulo

\section{CLEOMACEAE}

Bibliografia: Scalon \& Souza (2002), Iltis \& Cochrane (2007), Amaral et al. (2008).

31. Tarenaya hassleriana (Chodat) H.H.Ittis, Novon 17(4): 450. 2007.

Cleome hassleriana Chodat, Bull. Herb. Boissier 6(App. 1): 12. 1898.

Subarbusto anfíbio, ereto, $0,5-1,5 \mathrm{~m}$ alt., planta glandulo-hirsuta. Folhas alternas, pecíolos, 4$10 \mathrm{~cm}$ compr., pequenos espinhos e estípulas modificadas em acúleos, lâmina palmatissectas, 5-7 segmentos elíptico-lanceolados, 5-9x2cm, curtos espinhos nas nervuras primárias da face adaxial. Inflorescência em racemo, terminal, muitas brácteas foliares próximas umas das outras, simples, cordadas ou ovadas, $0,6-2 \times 0,4-1 \mathrm{~cm}$, flores solitárias em cada bráctea, brácteas florais próximas umas das outras. Flores com pedicelos $2-3 \mathrm{~cm}$ compr., 4 sépalas lineares, 4 pétalas dispostas em um lado da flor, rosadas a púrpuras, obovadas, base fortemente atenuada, 6 estames com longos filetes, $4-6 \mathrm{~cm}$ compr., rosados a púrpuros, anteras alongadas. Frutos pedicelados, síliquas cilíndricas. Planta nativa da América do Sul, distribuição cosmopolita. No Brasil ocorre no Centro-oeste (MT e GO) e de Pernambuco ao Sul do Brasil, atingindo Caatinga, Cerrado, Mata Atlântica e Pampa. Desenvolve-se bem em solo arenoso, em terreno úmido, suportando curtos períodos de solo encharcado. $\mathrm{Na}$ Represa Guarapiranga estava presente nos pontos PA1, RB5, IT11 e EM14. Facilmente reconhecida pelas flores vistosas rosadas, estípulas transformadas em acúleos e folhas palmatipartidas.

Material examinado: Represa Guarapiranga, GUA1, 3.V.2007, M.E.F.Rodrigues 119 (ESA). Represa Billings, 4B, 15.V.2007, M.E.F.Rodrigues 133 (ESA). Represa Guarapiranga, GUA6, 19.IX.2007, M.E.F.Rodrigues 226 (ESA). Represa Guarapiranga, GUA6, 10.X.2007, M.E.F.Rodrigues 253 (ESA).

\section{COMMELINACEAE}

Bibliografia: Barreto (2005), Amaral et al. (2008).

32. Commelina diffusa Burm.f., FI. Indica (N. L. Burman) 18, pl. 7, f. 2. 1768 .

Trapoeraba.

Erva anfíbia, semi-prostrada, ramos carnosos e pilosos. Folhas simples, alternas, sésseis, com bainha, lâmina, $2-5 \times 0,5-1 \mathrm{~cm}$, glabra, lanceolada, de bordo liso. Inflorescência em cimeira, terminal ou axilar, 2-3-flores, bráctea espatácea, pedúnculo 0,5$2 \mathrm{~cm}$ compr. Flores pediceladas, 3 sépalas alvas, hialinas, 3 pétalas azuis, sendo 2 unguiculadas reniformes 1 em forma de quilha com ápice agudo, 3 estames, 3 estaminódios. Fruto cápsula. Distribuição neotropical. Ocorre em todas as regiões do Brasil, atingindo Amazônia, Cerrado, Caatinga, Mata Atlântica e Pantanal. Geralmente encontrada em formações florestais e áreas cultivadas, desenvolve-se bem em lugares úmidos, como margens de canais ou várzeas. $\mathrm{Na}$ Represa Guarapiranga esteve presente nos pontos PA4, CC6 e EM14. Pode ser reconhecida pela inflorescência com bráctea espatácea e 2-3 flores de pétalas azuis.

Material examinado: Represa Guarapiranga, GUA6, 19.IX.2007, M.E.F.Rodrigues 229 (ESA). Represa Guarapiranga, GUA6, 10.X.2007, M.E.F.Rodrigues 249 (ESA). Represa Billings, D, 13.IV.2005, M.E.F.Rodrigues 18 (ESA). Represa Billings, P, 20.IV.2005, M.E.F.Rodrigues 44 (ESA). Represa Billings, 2B, 29.XI.2006, M.E.F.Rodrigues 80 (ESA).

\section{CONVOLVULACEAE} (2000).

Bibliografia: Simão-Bianchini (1998), Pott \& Pott

33. Ipomoea carnea Jacq., Enum. Syst. PI. 13. 1760. Algodão-bravo, mata-cabra.

Fig.: 4c

Arbusto ou subarbusto emergente, ereto, até $2 \mathrm{~m}$ alt., caules e ramos fistulosos, pubérulos. Folhas simples, alternas, pecioladas, pecíolo (2)-6cm, lâmina, $7-12 \times 2-7 \mathrm{~cm}$, levemente aveludadas, cordada a subsagitadas, ápice atenuado. Cimeiras corimbosas, pedunculadas, densifloras, axilares. Flores pediceladas, vistosas, corola campanulada, róseoviolácea. Cápsulas septígrafas, sementes densoseríceo-lanosa. Distribuição América Tropical. Amplamente distribuída no território brasileiro atingindo todos os biomas brasileiros. Desenvolve-se bem em locais com bastante umidade e temperatura elevada, tolera período de seca, voltando a florescer no período chuvoso. Na Represa Guarapiranga esteve presente em todos os períodos de coleta no ponto CC6. Facilmente reconhecida pelo porte robusto, caule e ramos fistulosos, flores vistosas, campanuladas, róseo-violácea e sementes com longos tricomas ferrugíneos.

Material examinado: Represa Paiva Castro, 4P, 26.III.2007, M.E.F.Rodrigues 116 (ESA). Represa Guarapiranga, CC6, 29.V.2008, M.E.F.Rodrigues 349 (ESA). Represa Guarapiranga, CC6, 7.VII.2008, M.E.F.Rodrigues 362 (ESA).

\section{CYPERACEAE}

Bibliografia: Kral (1971), Araujo \& Longhi-Wagner (1996), Luceno \& Alves (1997), Faria (1998), Kissmann \& Groth (2000), Pott \& Pott (2000). 
1. Plantas com folhas desenvolvidas

2. Folhas com lígula

3. Folhas dispostas na base do caule, brácteas involucrais 4-6, inflorescência globosa

4. Brácteas involucrais e caule glabro, lígula não ciliada

38. Cyperus intricatus

4'. Brácteas involucrais e caule estrigoso, lígula ciliada .................................................... 53. Oxycaryum cubense

3'. Folhas dispostas ao longo do caule, brácteas involucrais 1-3, inflorescência não globosa

5. Espiguetas dispostas em espiga densa, 3 brácteas involucrais, aquênio com utrículo inteiro e sem cerdas na base ............................................................................................................. 34. Carex polysticha

5'. Espiguetas dispostas em panículas curtas e laxas, 1 bráctea involucral, aquênio sem utrículo e com 4-6 cerdas na base

51. Fuirena incompleta

2'. Folhas sem lígula

6. Folhas filiformes até $6 \mathrm{~cm}$ de compr., base do estilete com longos tricomas cobrindo o aquênio

6' Folhas não filiformes maiores que $6 \mathrm{~cm}$ compr., base do estilete sem longos tricomas que cobrem o aquênio

7. Inflorescência 1-3 brácteas involucrais ou sem brácteas involucrais

8. Folhas dispostas ao longo do caule, ausência de folhas basais, inflorescência espiciforme, aquênio subgloboso, branco

60. Scleria distans

8'. Folhas dispostas na base do caule, inflorescência em glomérulo terminal, antelas ou corimbosas, aquênios obovados, elipsoides, trígono, lenticulares ou oval-oblongos, coloração palha, creme, castanha ou negra.

9. Plantas menores que $30 \mathrm{~cm}$ de alt.

10. Bainhas afilas presentes na base da planta, inflorescência formada por espiguetas densamente agrupada em um glomérulo terminal, verde clara ou esbranquiçada ................................................52. Kyllinga brevifolia

10'. Bainhas afilas ausentes, inflorescência com antelas ou corimbosa, castanho-amarelada ou avermelhada

11. Brácteas involucrais 3, inflorescência em antelas, aquênios obovados, lisos.........55. Pycreus lanceolatus

11'. Bráctea involucral 1 em cada corimbo, inflorescência corimbosa, aquênios elipsoides, rugosos

59. Rhynchospora riparia

9'. Plantas maiores que $30 \mathrm{~cm}$ de alt.

12. Inflorescência 2 (3) brácteas involucrais na base, aquênio trígono, sem cerdas na base ..36. Cyperus haspan

12'. Inflorescência 1-2 brácteas por corimbo ou glomérulo, aquênios lenticulares, cerdas na base

13. Plantas escabras, entrenós bem definidos, inflorescência em corimbos, espiguetas fusiformes agrupadas em fascículos

57. Rhynchospora corymbosa

13'. Plantas glabras, entrenós pouco definidos, inflorescência globosa, composta, espiguetas ovais agrupadas densamente em glomérulo .............................................58. Rhynchospora holoschoenoides

7'. Inflorescência mais de 3 brácteas involucrais dispostas espiraladamente na base formando um invólucro

14. Plantas decumbentes, folhas distribuídas ao longo dos ramos, bainhas geralmente avermelhadas

14'. Plantas eretas, folhas concentradas na parte basal dos ramos, bainhas esverdeadas

15. Inflorescência com um só conjunto de espiguetas fasciculadas no ápice do caule, aquênio oval-oblongo, secção transversal lenticular, 2 estigmas

54. Cyperus mundtii

15'. Inflorescência de outros tipos, aquênio elíptico, secção transversal triangular, 3 estigmas (Cyperus)

16. Espiguetas aglomeradas no ápice de ramos formando glomérulos

17. Caule com tricomas retrorsos na superfície e nos ângulos ...........................41. Cyperus surinamensis

17'. Caule escabro apenas nos ângulos

35. Cyperus entrerianus

16 '. Espiguetas dispostas ao longo de um eixo central formando espigas cilíndricas

18. Ápice dos raios das antelas com espigas divergentes guarnecidas por brácteas basais

18'. Ápice dos raios das antelas com espigas não guarnecidas por brácteas basais

19. Inflorescência de aspecto eriçado, espiguetas lineares que se entrelaçam, ráquilas com alas

19'. Inflorescência com espigas cilíndricas formadas por grande número de espiguetas comprimidas e com glumas disticamente imbricadas, ráquilas sem alas ou com alas membranáceas

37. Cyperus imbricatus

1'. Plantas com folhas reduzidas a bainha

20. Gluma basal fértil

20'. Gluma basal estéril

21. Secção do caule 4-angulado, com menor ou igual a $0,5 \mathrm{~mm}$ de diâmetro

42. Eleocharis bonariensis

21'. Secção do caule elíptico ou cilíndrico, maior que $0,5 \mathrm{~mm}$ de diâmetro

22. Caule com septos evidentes

23. Bainha superior com ápice truncado, mucronado, flor com 2 estames

46. Eleocharis minima 23'. Bainha superior com ápice oblíquo, levemente acuminado, flor com 3 estames ..... 44 . Eleocharis interstincta

22'. Caule sem septos evidentes

24. Bainha superior sem apêndice hialino no ápice

24'. Bainha superior com apêndice hialino no ápice

25. Aquênios enegrecidos a negros quando maduros, glumas férteis com nervuras centrais inconspícuas e laterais púrpuras

49. Eleocharis subarticulata 
25'. Aquênios castanhos, oliváceos, purpuráceos quando maduros, glumas férteis verdes na nervura central e castanha a púrpura nas laterais 26. Aquênio ferrugineo a purpuráceo, caule elíptico em secção transversal 26'. Aquênio oliváceo a castanho, caule circular em secção transversal

43. Eleocharis flavescens 48. Eleocharis sellowiana
34. Carex polysticha Boeckeler, Vidensk. Meddel. Dansk Naturhist. Foren. Kjøbenhavn, 1869: 157. 1869.

Erva anfíbia, ereta, até $50 \mathrm{~cm}$ alt., caule trigono, glabro. Folhas dispostas ao longo do caule, bainha membranosa, lâminas maiores que caule, $0,5 \mathrm{~cm}$ larg., estrigosas na margem. Inflorescência terminal, 3-5 espigas, $2-4 \times 0,5-1 \mathrm{~cm}$, monoicas, 3 brácteas involucrais desiguais, $9-36 \mathrm{~cm}$ compr., margens estrigosas. Flores unissexuais, densamente agrupadas, esverdeadas. Aquênio trígono, amarelado envolto por utrículo, ovoide, rostro apical oco, bifendido, textura paleácea, glabra, brilhante, nervuras evidentes. Distribuição no Paraguai, Uruguai, Argentina, Sul e Sudeste do Brasil, associada a Mata Atlântica e Pampa. Na Represa Guarapiranga esteve presente no ponto EM12, área de parque Estadual. Identificada pela inflorescência em espigas e aquênio envolto por utrículo.

Material examinado: Represa Guarapiranga, EM12, 3.XII.2008, M.E.F.Rodrigues 484 (ESA).

35. Cyperus entrerianus Boeckeler, Flora 61: 139. 1878.

Tiririca, três-quinas, junquinho, junça.

Erva anfíbia, ereta, $70 \mathrm{~cm}$ alt., cespitosa, colmo liso com ângulos escabrosos. Folhas basais 10, comprimento igual ou maior que caule, coriáceas, carenadas, escabrosas na margem e carena, lanceoladas. Brácteas involucrais 5, desiguais, semelhantes às lâminas foliares. Inflorescência em antela composta contraída, raios de comprimento desiguais, 10-12 raios primários, espiguetas reunidas em glomérulos densos no ápice. Espiguetas ovais, glumas carenadas, verdes ou amareladas. Aquênio elíptico, trigonos, 1-1,2mm compr., castanho. Amplamente distribuída na América do Sul. Ocorre do Nordeste ao Sul do Brasil, atingindo Caatinga, Cerrado, Mata Atlântica e Pampa. Desenvolve-se bem em solos modificados onde tenha boa umidade. $\mathrm{Na}$ Represa Guarapiranga esteve presente nos pontos IT9, EM12 e EM13. Espécie muito semelhante à Cyperus surinamensis, diferenciando-se através do caule escabroso apenas nos ângulos, com os tricomas não retrorsos.

Material examinado: Represa Guarapiranga, IT9, 29.V.2008, M.E.F.Rodrigues 000352B (ESA). Represa Guarapiranga, EM13, 6.XI.2008, M.E.F.Rodrigues 000446B (ESA). Represa Guarapiranga, EM12, 6.XI.2008, M.E.F.Rodrigues 455 (ESA).
36. Cyperus haspan L., Sp. pl. 1: 45. 1753.

Tiririca, três-quinas, junquinho, junça.

Erva anfíbia, ereta, até $90 \mathrm{~cm}$ alt., cespitosa. Folhas basais, lâminas pouco desenvolvidas, algumas plantas reduzidas a bainha membranácea, pardoavermelhada, outras possuem bainha e lâminas acuminadas, mais curtas que caule, $2-5 \mathrm{~mm}$ larg. Brácteas involucrais 2, sendo uma mais curta que raios da antela e outra mais comprida e ereta parecendo continuação do caule. Inflorescência de antelas laxas, raios primários a quartenários, os últimos raios sustentam fascículos de 2-3 espiguetas. Espigueta séssil, linear-lanceolada, glumas de coloração púrpura, nervação verde, apiculadas, e margens pardas, dísticas. Aquênio elíptico-obovado, trígono, superfície branca com pontos brilhantes. Amplamente distribuída desde o sul dos Estados Unidos até Argentina. Ocorre em todo território brasileiro, atingindo todos os biomas brasileiros. Frequentemente encontrada nas margens de canais pouco profundos de irrigação e drenagem, inclusive em lavoura de arroz irrigado. $\mathrm{Na}$ Represa Guarapiranga esteve presente apenas no ponto EM12, localizado dentro de uma área de parque estadual. Pode ser identificada através das inflorescências de antelas laxas com espiguetas ferrugíneas e uma bráctea involucral maior que raios da antela e ereta.

Material examinado: Represa Guarapiranga, EM12, 6.XI.2008, M.E.F.Rodrigues 453 (ESA, HURG). Represa Guarapiranga, EM12, 16.X.2008, M.E.F.Rodrigues 425 (ESA, HURG).

37. Cyperus imbricatus Retz., Observ. Bot. 5: 12. 1788.

Tiririca, três-quinas, junquinho, junça.

Erva anfíbia, ereta, $1 \mathrm{~m}$ alt., cespitosa. Folhas, $73 \mathrm{~cm}$ compr., bicarenadas, margens e carenas escabras, verde-pálida. Brácteas involucrais 6 , sendo 3 mais longas que raios da antela, semelhantes às lâminas foliares. Inflorescência em antela não contraída, 10 raios primários de comprimento irregular, 4-12,5cm compr., espigas sésseis, cilíndricas no ápice. Espigueta subséssil, linear, gluma com múcron, esverdeada no dorso e amarelada no bordo. Aquênio trígono-elipsóide, amarelo-palha. Ampla distribuição nas regiões tropicais do mundo. Ocorre do Nordeste ao Sul do Brasil, atingindo Caatinga, Cerrado, Mata Atlântica, Pantanal e Pampa. Ocorre em baixadas 
úmidas, com temperatura elevada e boa iluminação, desenvolve-se também em solos ácidos e pobres. $\mathrm{Na}$ Represa esteve presente no ponto CC8. Reconhecido pelas espigas cilíndricas agrupadas geralmente em 3 , uma ereta e duas laterais e de coloração amareloouro.

Material examinado: Represa Guarapiranga, CC8, 7.VII.2008, M.E.F.Rodrigues 366 (ESA).

38. Cyperus intricatus Schrad. ex Schult., Mant. 2: 98.1824.

Erva anfíbia, ereta, $1,32 \mathrm{~m}$ alt. Folhas escassas, as primeiras folhas reduzidas às bainhas, demais folhas com lígula membranosa, lâminas linearlanceoladas, geralmente menores que 0 caule. Brácteas involucrais 3-4, desiguais, tendo uma que se destaca por ser mais comprida e mais larga que as demais, de até $40 \times 1,2 \mathrm{~cm}$. Inflorescência em antela aberta composta de glomérulos globosos formados pelas espiguetas densamente agrupadas, lineares ou oblongo-lineares, glumas dispostas em duas séries opostas, flores com 1-2 estames, estigma 3-fido. Aquênios elípticos, trígonos, castanho-claro, brilhante. Distribuição pantropical. No Brasil ocorre no CentroOeste (MS), Sudeste e Sul, atingindo Cerrado, Mata Atlântica e Pampa. Na Represa Guarapiranga esteve presente no ponto EM12. Inflorescência semelhante à Rhynchospora holoschoenoides e Oxycaryum cubense, mas diferencia-se destas pela presença de lígula membranosa, enquanto a primeira não possui lígula e a segunda possui lígula membranoso-ciliada, e pelos aquênios trígonos e base do estilete não persistente em $C$. intricatus, enquanto as demais possuem aquênios lenticulares e base do estilete persistente.

Material examinado: Represa Guarapiranga, EM12, 3.XII.2008, M.E.F.Rodrigues 485 (ESA, HURG).

39. Cyperus odoratus L., Sp. pl. 1: 46. 1753.

Cyperus ferax L.C. Rich, Actes Soc. Hist. Nat. Paris 1: 1061792.

Tiriricão, três-quinas, junquinho, junça, junca-deouriço.

Erva emergente, ereta, $40 \mathrm{~cm}$ alt., cespitosa. Folhas basais $2-3$, geralmente de comprimento igual ou maior que caule, lâminas lineares, 4-6mm larg., escabrosas nas margens e nervuras do ápice da folha. Brácteas involucrais 4-6, semelhante às folhas, escabrosas. Inflorescência em antelas, vários raios primários de diferentes tamanhos, raios menores apenas uma espiga terminal e raios maiores até 6 raios secundários, espigas cilíndricas, muitas espiguetas lineares, ráquilas com alas corticosas, glumas com dorso arredondado e carenado, castanhoamarelada, carena verde, margens castanhoavermelhadas. Aquênio elíptico, trígono, castanho- avermelhado, fosco ou levemente brilhante. Distribuição cosmopolita das regiões tropicais e subtropicais do mundo. Ocorre em todo território brasileiro, atingindo todos os biomas brasileiros. Pouco exigente quanto à constituição física do solo, desenvolvendo-se de forma mais agressiva em solos úmidos. Na Represa Guarapiranga foi encontrada nos pontos RB5, IT9, EM12 e EG17. Pode ser identificada quando madura pela inflorescência com espigas globosas e eriçadas de espiguetas lineares e pelas ráquilas que possuem alas corticosas e se desarticulam em cada nó da espigueta.

Material examinado: Represa Guarapiranga, GUA2, 14.XII.2007, M.E.F.Rodrigues 328 (ESA). Represa Guarapiranga, 9G, 30.I.2007, M.E.F.Rodrigues 103 (ESA). Represa Billings, D, 13.IV.2005, M.E.F.Rodrigues 14 (ESA). Represa Guarapiranga, GUA6, 9.XI.2007, M.E.F.Rodrigues 307 (ESA, HURG).

40. Cyperus pohlii (Nees) Steud., Syn. PI. Glumac. 2: 40.1854.

Erva anfíbia, ereta, 1,5m alt., cespitosa. Caule trígono com faces deprimidas, glabro. Folhas basais, 3-6, de comprimento igual ou maior que caule, 1,2mm larg., bainhas largas, avermelhadas. Brácteas involucrais 6-10, desiguais, margens e carenas escabrosas. Inflorescência em antelas compostas, raios de comprimentos muito variados, $7-23 \mathrm{~cm}$ compr., 1-8 espigas apicais divergentes, guarnecidas por brácteas lineares, espigas pediceladas, subcilíndricas, grande número de espiguetas guarnecidas por brácteas lineares, glumas amarelo-palha a acastanhas. Aquênio oblongo ou elíptico, trígono. Distribuição no continente americano. Ocorre do Nordeste ao Sul, atingindo Caatinga, Cerrado, Mata Atlântica, Pantanal e Pampa. Na Represa Guarapiranga esteve presente apenas no ponto EM12. Pode ser identificada através da inflorescência que possui conjunto de espigas guarnecidas por brácteas no ápice do raio primário e espiguetas com brácteas lineares na base.

Material examinado: Represa Guarapiranga, EM12, 3.XII.2008, M.E.F.Rodrigues 480 (ESA, HURG).

41. Cyperus surinamensis Rottb., Descr. PI. Rar. 20. 1772 .

Tiririca, três-quinas, junquinho, junça.

Erva emergente, ereta, $26 \mathrm{~cm}$ alt., caule com tricomas retrorsos na superfície e nos ângulos do caule. Folhas basais 5-7, menores que caule, até $5 \mathrm{~mm}$ larg., dobradas, longamente acuminadas. Brácteas involucrais 3-5, desiguais, geralmente com a bráctea posterior ereta parecendo uma continuação do caule. Inflorescência em antelas compostas, raios primários e secundários, no ápice de cada raio há um conjunto de espiguetas lanceoladas ou ovadas, achatadas, glumas 
naviculares. Aquênio ovado-oblongo, levemente trígono, 0,6-0,8mm compr., rugoso e pontuado, vermelho-acastanhado. Distribuição na América tropical e subtropical. Ocorre em todo território brasileiro, atingindo todos os biomas brasileiros. Desenvolve-se em solos pobres, inclusive salinos, porém o desenvolvimento é mais acentuado em solos férteis com boa umidade. Na Represa Guarapiranga esteve presente nos pontos RB5, IT9 e EG16. Espécie muito semelhante a $C$. entrerianus da qual pode ser diferenciada pela presença de tricomas retrorsos em todo caule.

Material examinado: Represa Guarapiranga, IT9, 29.V.2008, M.E.F.Rodrigues 000352A (ESA, HURG). Represa Guarapiranga, EG16, 4.XII.2008, M.E.F.Rodrigues 507 (ESA). Represa Guarapiranga, GUA5, 10.X.2007, M.E.F.Rodrigues 237 (ESA, HURG).

42. Eleocharis bonariensis Nees, London J. Bot. 2: 398. 1840.

Fig.: 4d

Erva emergente, cespitosa e estolonífera. Caule $5-16 \times 0,05 \mathrm{~cm}$. Bainha superior com ápice obliquamente alongado, ocráceo, base ocrácea a purpurácea. Espigueta 3-4mm diâm, elíptica a lanceolada, flores espiraladas, gluma basal fértil, glumas férteis com nervuras centrais ocráceas a amareladas, laterais amareladas com mancha púrpura, margem hialina, 3-4 cerdas hipóginas, 3 estames, estilete 3-fido. Aquênio cilíndrico, elipsóide, ocráceo a castanho, superfície reticulada. Distribuição na América do Sul, Meridional e introduzida na Europa. No Brasil ocorre em São Paulo e Sul, atingindo Mata Atlântica e Pampa. Comum em alagados e margens de riacho. $\mathrm{Na}$ Represa Guarapiranga esteve presente apenas no ponto EM12 localizado no Parque Estadual. Segundo Farias (1998) esta espécie é rara no estado de São Paulo, tendo sido encontrada somente em Campos do Jordão. Pode ser identificada por duas glumas basais férteis que alcançam metade do comprimento da espigueta e pelo aquênio cilíndrico e reticulado.

Material examinado: Represa Guarapiranga, EM12, 16.X.2008, M.E.F.Rodrigues 431 (ESA, FUEL).

43. Eleocharis flavescens (Poir.) Urb., Symb. Antill. 4(1): 116. 1903.

Erva emergente, cespitosa e estolonífera. Caule $(1,5) 4-8(12) \times 0,1 \mathrm{~cm}$. Bainha superior com apêndice hialino no ápice, base ocrácea a purpurácea. Espigueta $2-4 \mathrm{~mm}$, oval a oval-lanceolada, 2 glumas basais estéreis, glumas férteis com nervuras centrais esverdeadas a ocráceas, laterais ocráceas a castanhas, margens hialinas, 6-9 cerdas hipóginas, 3 estames, estilete 2-fido. Aquênio 2-convexo, obovoide, ocráceo, esverdeado, oliváceo a lilás quando imaturo e purpuráceo a ferrugineo quando maduro, superfície lisa. Distribuição da América do Norte ao Sul. Ocorre no Nordeste, Sudeste e Sul do Brasil, atingindo Caatinga e Mata Atlântica. Comum em alagados, margem de córregos, alagados e em solos arenosos encharcados. Na Represa Guarapiranga esteve presente nos pontos IT10, EM14, EG16. Espécie diferencia-se de E. sellowiana pela seção transversal do caule elíptica e aquênio purpuráceo a ferrugíneo.

Material examinado: Represa Billings, D, 13.IV.2005, M.E.F.Rodrigues 21 (ESA). Represa Guarapiranga, EM14, 6.XI.2008, M.E.F.Rodrigues 000461A (ESA, FUEL). Represa Guarapiranga, EM14, 6.XI.2008, M.E.F.Rodrigues 547 (ESA, FUEL). Represa Billings, ponto 6 (transecto), 30.V.2007, M.E.F.Rodrigues 194 (ESA).

44. Eleocharis interstincta (Vahl) Roem. \& Schult., Syst. Veg. 2: 149. 1817.

Erva emergente, cespitosa a estolonífera. Caules até $65 \times 0,6 \mathrm{~cm}$, circular em seção transversal, septos externamente evidentes. Bainha superior com ápice oblíquo, levemente acuminado, púrpura, base ocrácea a púrpura, bainha inferior membranácea. Espiguetas cilíndricas, 1-2 glumas basais estéreis, prolongando-se desde o caule, glumas verdes a ocráceas, 6-7 cerdas hipóginas, denteadas, menores que o aquênio, 3 estames, estilete 2-3-fido. Aquênio 2convexo, obovoide, verde quando imaturo e ferrugíneo quando maduro, superfície reticulada, base do estilete lameliforme. Distribuição na Índia e América. No Brasil ocorre em todas as regiões, atingindo Amazônia, Caatinga, Cerrado, Pantanal e Mata Atlântica. Comuns em canais de água, lagoas rasas, margens de lagos e alagados. Na Represa Guarapiranga esteve presente nos pontos EM14 e EG16. Identificada pelos septos evidentes assim como E. maculosa, diferenciando-se desta por ter 3 estames e bainha com ápice oblíquo levemente acuminado.

Material examinado: Represa Billings, $U$, 11.V.2005, M.E.F.Rodrigues 54 (ESA). Represa Guarapiranga, EM14, 6.XI.2008, M.E.F.Rodrigues 458 (ESA, FUEL). Represa Billings, ponto 6 (transecto), 30.V.2007, M.E.F.Rodrigues 187 (ESA).

45. Eleocharis maculosa (Vahl) Roem. \& Schult., Syst. Veg. 2: 154. 1817.

Erva emergente, cespitosa e estolonífera. Caule 7-30-(45) x0,1 cm, elíptico em seção transversal. Bainha superior com apêndice hialino no ápice, base purpurácea. Espigueta, 6-10mm diâm, oval a lanceolada, mais que 3 glumas basais estéreis, nervuras centrais ocráceas a esverdeadas, laterais ocráceas a púrpuras, margens hialinas 6-7 cerdas hipóginas, 3 estames, estilete 2-fido. Aquênio 2convexo, obovoide, enegrecido quando maduro, superfície lisa. Distribuição na Índia, América Central e América do Sul. No Brasil ocorre no Norte (RR), 
Nordeste, Centro-Oeste (MS), Sudeste e Sul, atingindo todos os biomas brasileiros. Comuns em alagados, solos alagados, margens de rio, solos úmidos em locais sombreados no interior da mata. $\mathrm{Na}$ Represa Guarapiranga esteve presente somente no ponto PA2. Facilmente identificada pelos aquênios enegrecidos, pelas glumas fortemente púrpuras e pelo apêndice hialino na bainha superior.

Material examinado: Represa Guarapiranga, PA2, 4.XII.2008, M.E.F.Rodrigues 526 (ESA, FUEL). Represa Guarapiranga, GUA4, 14.XII.2007, M.E.F.Rodrigues 337 (ESA, FUEL). Represa Guarapiranga, PA2, 4.XII.2008, M.E.F.Rodrigues 559 (ESA, FUEL).

46. Eleocharis minima Kunth, Enum. PI. 2: 139140. 1837.

Erva emergente, cespitosa e estolonífera. Caule 2-7,5x0,03cm, quadrangular em seção transversal. Bainha superior com ápice acuminado, escarioso, ocráceo, base ocrácea. Espiguetas de até $4 \mathrm{~mm}$, lanceolada, flores subdísticas a espiraladas, gluma basal estéril presente, glumas férteis com nervuras centrais ocráceas a esverdeadas, laterais ocráceas, geralmente púrpuras na região submarginal e ao lado das nervuras centrais, cerdas hipóginas rudimentares ou ausentes, 2 estames, estilete 2-3-fido. Aquênio 2-3-convexo, ocráceo, superfície lisa. Distribuição na América. Ocorre em todo território brasileiro, atingindo Amazônia, Caatinga, Cerrado, Mata Atlântica e Pampa. Ocorre em margens de riachos, margens de lagos, várzeas e alagados. $\mathrm{Na}$ Represa Guarapiranga esteve presente apenas no ponto EM14. Identificada pelo porte capiláceo, caule 4angulado e flores subdísticas.

Material examinado: Represa Guarapiranga, EM14, 6.XI.2008, M.E.F.Rodrigues 000461B (ESA, FUEL)

47. Eleocharis montana (Kunth) Roem. \& Schult., Syst. Veg. 2: 153. 1817.

Erva emergente, cespitosa e rizomatosa. Caule $20-45 \times 0,1-0,3 \mathrm{~cm}$, circular em seção transversal com septos externamente evidentes. Bainha superior com ápice truncado, mucronado, acráceo a purpuráceo, base púrpura. Espiguetas 0,5-1,3cm, lanceolada, glumas basais estéreis 3 ou mais, glumas férteis com nervuras centrais esverdeadas, laterais castanhas a ferrugíneas, margens hialinas amplas. 4-6 cerdas hipóginas, 2 estames, estilete 2-3-fido. Aquênio obovoide a levemente elipsóide, amarelo sem manchas ou oliváceo a ferrugíneo com manchas escuras quando maduro, superfície reticulada. Distribuição na Índia e América. No Brasil ocorre no Nordeste, Centro-Oeste, Sudeste e Sul atingindo Caatinga, Cerrado, Mata Atlântica e Pampa. Ocorre em solos alagados, margens de rios, riachos, lagoas e lagos. Na Represa Guarapiranga esteve presente apenas no ponto EG17. Identificada pela bainha com ápice truncado e mucronado.

Material examinado: Represa Guarapiranga, EG17, 5.XI.2008, M.E.F.Rodrigues 437 (ESA, FUEL).

48. Eleocharis sellowiana Kunth, Enum. PI. 2: 149. 1837.

Junco, junco-manso.

Erva emergente, cespitosa e estolonífera. Caule $3-20 \times 0,1 \mathrm{~cm}$, circular em seção transversal. Bainha superior com apêndice hialino no ápice, base ocrácea a purpurácea. Espigueta, 3-8mm, elipsóide a lanceolada, 2 glumas basais estéreis, glumas férteis com nervuras centrais esverdeadas, ocráceas ou castanhas laterais castanhas a ferrugíneas, margens hialinas, 7-8 cerdas hipóginas, 3 estames, estilete 2fido. Aquênio, obovoide, oliváceo a castanho-claro, superfície lisa. Distribuição na América do Sul e Central. No Brasil ocorre em todos estados, atingindo todos os biomas brasileiros. Ocorre em solos alagados, margens de rios, riachos, lagoas e lagos, desenvolve-se em solos arenosos e relativamente pobres. Na Represa Guarapiranga esteve presente nos pontos PA2, IT11, EG15 e EG17. É uma espécie de grande plasticidade, variando muito no tamanho e espessura do caule $(8-60 \times 0,08-0,2 \mathrm{~cm})$ e espigueta $(4,5-11 \mathrm{~mm})$ (Faria, 1998). Diferencia-se de $E$. flavescens pelo caule circular em seção transversal e aquênio oliváceo a castanho claro.

Material examinado: Represa Guarapiranga, EG15, 4.XII.2008, M.E.F.Rodrigues 558 (ESA, FUEL). Represa Guarapiranga, IT11, 3.XII.2008, M.E.F.Rodrigues 471 (ESA, FUEL). Represa Guarapiranga, GUA4, 14.XII.2007, M.E.F.Rodrigues 331 (ESA, FUEL). Represa Guarapiranga, EG17, 4.XII.2008, M.E.F.Rodrigues 499 (ESA, FUEL).

49. Eleocharis subarticulata Boeckeler, Linnaea 36: 455. 1869.

Erva emergente, cespitosa e estolonífera. Caule 2-8,5x0,05-0,1cm, circular em seção transversal, septos não evidentes externamente. Bainha superior com ápice obliquo, ocráceo a castanho, base ocrácea, ás vezes, purpurácea. Espiguetas 3-6mm, lanceoladas a cilíndrica, 1-2 glumas basais estéreis, nervuras centrais prolongando-se desde o caule, verdes, glumas férteis com nervuras centrais verdes, laterais castanhas a púrpuras, margens hialinas, 6-7 cerdas hipóginas, 3 estames, estilete 3-fido. Aquênio, obovoide, oliváceobrilhante a castanho, superfície reticulada. Distribuição na América do Sul. No Brasil ocorre no Sudeste e Sul, atingindo Cerrado, Mata Atlântica e Pampa. Ocorre em solos alagados, margens de lagos, dentro de riachos e lagoas rasas. $\mathrm{Na}$ Represa Guarapiranga esteve presente apenas no ponto EG15. Pode ser identificada pelas glumas com nervuras centrais esverdeadas e 
Levantamento de plantas aquáticas e palustres na represa Guarapiranga, São Paulo

laterais e ápice purpuráceos e aquênios oliváceobrilhante.

Material examinado: Represa Guarapiranga, EG15, 4.XII.2008, M.E.F.Rodrigues 512 (ESA, FUEL). Represa Guarapiranga, EG15, 7.I.2009, M.E.F.Rodrigues 533 (ESA, FUEL).

50. Fimbristylis squarrosa Vahl, Enum. PI. 2: 289. 1805. (1806).

Erva anfíbia, cespitosa, de $4-10 \mathrm{~cm}$ alt. Folhas lineares filiformes, de comprimento maior ou na metade do caule, menores que $0,5 \mathrm{~mm}$ larg., bainha hirsuta ou pilosa. Caules delgados, eretos. Inflorescência do tipo umbela aberta ou cimeiras geralmente com 5 espiguetas elipsóides, oblongas, agudas, 4-5mm compr., glumas férteis esverdeadas a ocráceas, ápice longamente atenuado, brácteas involucrais presentes, sendo uma maior que a inflorescência e outras menores. Aquênio lenticularobovoide, amarelo-palha, base do estilete com longos tricomas que cobrem metade do aquênio. Distribuição no Velho Mundo, América do Norte e do Sul. Ocorre no Norte (TO), Nordeste (BA, PE, PI), Centro-Oeste (MS, GO), Sudeste (MG, SP, RJ) e Sul (PR), atingindo Amazônia, Cerrado, Mata Atlântica, Pantanal e Pampa. Considerada erva daninha tropical em lugares úmidos. Na Represa Guarapiranga foi encontrada frequentemente nos pontos CC6, EM14, EG19 e raramente nos pontos PA1, PA2, RB5, EG15, EG16 e EG17. Pode ser identificada pelo porte capiláceo, folhas lineares, inflorescência com 5 ou mais espiguetas elipsóides e base do estilete com tricomas longos que cobrem parte do aquênio.

Material examinado: Represa Guarapiranga, GUA5, 10.X.2007, M.E.F.Rodrigues 239 (ESA). Represa Guarapiranga, CC6, 16.X.2008, M.E.F.Rodrigues 430 (ESA). Represa Guarapiranga, EM14, 6.XI.2008, M.E.F.Rodrigues 538 (ESA).

51. Fuirena incompleta Nees in Mart., Fl. bras. 2(1): 107. 1842.

Erva anfíbia, ereta, $40 \mathrm{~cm}$ alt., cespitosa. Geralmente 3 folhas dispostas ao longo do caule, lâminas, linear-lanceoladas, 4-10×0,1-0,2cm, glabras, presença de lígula membranácea. Apenas 1 bráctea involucral foliácea. Inflorescência terminal ou lateral, geralmente de 3-5 espiguetas elípticas, glumas dispostas em espiral, castanho-esverdeadas, aristas verdes, flores com 3 estames de filete ferrugíneo e ultrapassando gluma após queda da antera, estigma 3-fido ferrugíneo. Aquênio trígono, elíptico, castanhoamarelado, 6 cerdas na base, 3 do mesmo comprimento do aquênio e 3 menores. Distribuição na América Central e do Sul. No Brasil ocorrem no Norte (AM, RR), Nordeste (BA, MA, PI), Centro-Oeste (GO, MS, MT), Sudeste e Sul (PR), atingindo Amazônia, Caatinga, Cerrado, Pantanal e Mata Atlântica. Na
Represa Guarapiranga esteve presente no ponto EG15. Pode ser identificada pelas características da inflorescência e presença de lígula.

Material examinado: Represa Guarapiranga, EG15,
4.XII.2008, M.E.F.Rodrigues $510 \quad$ (ESA) Represa
Guarapiranga, EG15, 7.I.2009, M.E.F.Rodrigues 531 (ESA).

52. Kyllinga brevifolia Rottb., Descr. Icon. Rar. PI. 13, pl. 4, f. 3. 1773.

Junquinho.

Erva anfíbia, ereta, até $9 \mathrm{~cm}$ alt., rizomas delgados. Presença de 3 bainhas áfilas na base do caule e 1-2 que apresentam lâminas mais curtas que 0 caule, 2-6x0,1-0,3cm, lineares, lisas, glabras, coloração verde intensa. Brácteas involucrais 3 , de comprimentos variados, $1-7 \mathrm{~cm}$, margem levemente escabrosa. Inflorescência terminal monocéfala subglobosa ou oval, até $1 \mathrm{~cm}$ alt., verde durante desenvolvimento e branca na maturação. Espiguetas compressas, sésseis, lanceoladas e comprimidas, unifloras, flor hermafrodita com 2 estames e estilete bífido. Aquênio oboval-elíptico, ocráceo, superfície com pontuações salientes. Distribuição pantropical e subtropical. No Brasil ocorre em todos os estados, atingindo todos os biomas brasileiros. Desenvolve-se bem em locais úmidos e temperatura não muito baixa e tolera sombreamento moderado. $\mathrm{Na}$ Represa Guarapiranga esteve presente apenas no ponto EM14. Identificada pela inflorescência monocéfala, terminal, globosa e esverdeada a branquicenta.

Material examinado: Represa Guarapiranga, EM14, 6.XI.2008, M.E.F.Rodrigues 546 (ESA).

53. Oxycaryum cubense (Poepp. \& Kunth) Palla, Denkschr. Kaiserl. Akad. Wiss., Math-Naturwiss. KI. 79(1): 169. 1908.

Erva emergente ou epífita, ereta, $75 \mathrm{~cm}$ alt., estolonífera. Folhas basais com bainha aberta e presença de lígula membranoso-ciliada, lâminas menores que o caule, $2-4 \mathrm{~mm}$ larg., linear-lanceoladas, face adaxial estrigosa nas margens e nervuras, face abaxial glauca. Brácteas involucrais $5-6$, as basais mais desenvolvidas que as demais, até $56 \mathrm{~cm}$ comp. Inflorescência em antelas simples, até 10 glomérulos globosos, formados pelas espiguetas sésseis, castanho-amareladas, dispostas em espiral, flores com 3 estames, anteras de ápice apiculado, estilete 2fido. Aquênio, elíptico, achatado dorsiventralmente, oliváceo, base do estilete persistente de ápice acuminado. Distribuição do México ao Brasil e Paraguai, Antilhas e África tropical. No Brasil ocorre em todos estados, atingindo todos os biomas brasileiros. Na Represa Guarapiranga esteve presente no ponto EG17, foi observada como epífita sobre Salvinia herzogii próximo aos pontos do Rio Parelheiros. Inflorescência semelhante à 
Rhynchospora holoschoenoides e Cyperus intricatus, mas diferencia-se destas pela presença de lígula membranoso-ciliada e aquênio com base do estilete persistente e não engrossado.

Material examinado: Represa Guarapiranga, EG17, 4.XII.2008, M.E.F.Rodrigues 491 (ESA).

54. Cyperus mundtii (Nees) Kunth, Enum. PI. 2: 17. 1837.

Pycreus decumbens T. Koyama, Bull. Natl. Sci. Mus. Tokyo, B 2(4): 167, f. 1. 1976.

Junquinho.

Erva anfíbia, decumbente, até $2 \mathrm{~m}$ alt., estolonífera. Bainhas com tonalidade avermelhada. Folhas espaçadas ao longo do caule até alcançar um eixo áfilo na extremidade do ramo florífero, lâminas linear-lanceoladas, $7-13 \times 0,3-0,5 \mathrm{~cm}$, glabras. Mais de 3 brácteas involucrais de comprimentos variados, $1-8 \mathrm{~cm}$ compr., mais curtas que raios das antelas. Inflorescência em antelas terminais, formada por 12 raios de comprimento irregular, os raios maiores podem apresentar $1-3$ raios secundários, até $3 \mathrm{~cm}$ compr., no ápice de cada raio há até 9 espiguetas divergentes para todos os lados. Espigueta séssil, lanceolada, $\quad 0,5-1,0 \times 0,2-0,3 \mathrm{~cm}$, castanhoavermelhada, flores com 3 estames e 2 estigmas. Aquênio oboval, lenticular em secção transversal, glauco-castanho. Planta nativa do Brasil ocorrendo nas regiões Sudeste (MG, SP, RJ) e Sul (SC, PR), está associada apenas a Mata Atlântica. Habita lugares muito úmidos e alagados. Na Represa Guarapiranga esteve frequentemente presente nos pontos IT11, EM12, EM14 e EG15 e raramente nos pontos PA1 e CC6. É identificada pelos longos ramos enfolhados com bainhas e inflorescência avermelhadas.

Material examinado: Represa Guarapiranga, 5G, 19.I.2007, M.E.F.Rodrigues 85 (ESA, HURG). Represa Guarapiranga, EM12, 8.VII.2008, M.E.F.Rodrigues 379 (ESA, HURG). Represa Guarapiranga, IT11, 3.IX.2008, M.E.F.Rodrigues 413 (ESA). Represa Guarapiranga, EM12, 6.XI.2008, M.E.F.Rodrigues 456 (ESA).

55. Pycreus lanceolatus (Poir.) C.B.Clarke, Consp. FI. Afr. 5: 538. 1894.

Erva anfíbia, ereta, até $15 \mathrm{~cm}$ alt., cespitosa. Folhas basais com lâminas lineares, geralmente menores que o caule, até $2 \mathrm{~mm}$ larg., margens escabrosas. Brácteas involucrais 3-4, de comprimentos variados, $2-8 \mathrm{~cm}$ compr., maiores que inflorescência. Antela formada por um agrupamento de espiguetas no ápice do caule e outros 2-3 nas pontas de eixos filiformes. Espiguetas subsésseis, linearlanceoladas, achatada, glumas verde-claras a amarelado-acastanhadas, translúcidas, dísticas, flores com 2 estames e 2 estigmas. Aquênio obovado, lenticular, castanho a ferrugíneo. Distribuição na
América subtropical e África. No Brasil ocorre no Norte (PA), Nordeste, Centro-Oeste, Sudeste e Sul, atingindo todos os biomas brasileiros. Ocorre em lugares úmidos, desenvolvendo-se bem em solos médios, ricos em matéria orgânica. $\mathrm{Na}$ Represa Guarapiranga esteve presente EM14, EG16, EG17 e EG19. Identificada pelas espiguetas lanceoladas, fortemente achatadas e translúcidas.

Material examinado: Represa Guarapiranga, EG19, 4.XII.2008, M.E.F.Rodrigues 498 (ESA). Represa Guarapiranga, EM14, 6.XI.2008, M.E.F.Rodrigues 541 (ESA). Represa Guarapiranga, EG17, 4.XII.2008, M.E.F.Rodrigues 494 (ESA, HURG).

56. Pycreus polystachyos (Rottb.) P.Beauv., FI. Oware 2: 48. 1807.

Erva anfíbia, ereta, até $30 \mathrm{~cm}$ alt., cespitosa. Folhas basais abundantes, lâminas mais curtas que caule, até $5 \mathrm{~mm}$ larg., margens e carenas escabrosas. Brácteas involucrais 3-5 de comprimentos variados, maiores que inflorescência. Antela contraída monocéfala e terminal. Espiguetas subsésseis, linearlanceoladas, achatada, amarelo-castanho a ferrugínea com carena esverdeada. Aquênio elíptico, lenticular em secção transversal, pardo-avermelhado a negro, pontuações proeminentes. Distribuição em regiões de clima tropical ou subtropical. Ocorre em todo território brasileiro, associada a todos os biomas brasileiros. Desenvolve-se bem em áreas úmidas, mas não alagadas. Na Represa Guarapiranga esteve presente raramente nos pontos PA2, RB5 e EM14. Identificada pelos fascículos de espiguetas aproximadas na base e divergentes no ápice.

Material examinado: Represa Guarapiranga, 7G, 30.I.2007, M.E.F.Rodrigues 95 (ESA, HURG). Represa Guarapiranga, PA2, 4.XII.2008, M.E.F.Rodrigues 527 (ESA).

57. Rhynchospora corymbosa (L.) Britton, Trans. New York Acad. Sci. 11: 84. 1892.

Rhynchospora aurea Vahl, Enum. PI. 2: 229. 1805

Capim-navalha, navalha-de-macaco.

Erva anfíbia, ereta, $2 \mathrm{~m}$ alt., cespitosa. Caule trígono de ângulos obtusos, escabroso. Presença de folhas basais e caulinares, lanceoladas, escabrosas nas margens. Inflorescência com mais de 3 corimbos terminais e axilares, se desenvolvendo a partir de um nó onde se origina uma bráctea involucral. Espiguetas curto-pedunculadas, fusiformes, castanho-claras, agrupadas em fascículos no fim dos raios secundários ou terciários. Aquênio oboval, castanho, rostro no ápice de comprimento igual ou maior que seu corpo, 5-6 cerdas hipóginas avermelhadas. Planta pantropical, ampla distribuição nas Américas. Ocorre em todo território brasileiro, atingindo todos os biomas brasileiros. Típica de áreas úmidas, tolera solo ácido e suporta uma grande faixa de temperaturas. $\mathrm{Na}$ Represa Guarapiranga esteve presente nos pontos 
EM12 e EG17. Pode ser identificada pelo caule com entrenós que se destacam facilmente, espiguetas fusiformes agrupadas em fascículos e aquênio com rostro igual ou maior que seu corpo.

Material examinado: Represa Guarapiranga, EG17, 4.XII.2008, M.E.F.Rodrigues 497 (ESA). Represa Guarapiranga, EM12, 16.X.2008, M.E.F.Rodrigues 422 (ESA). Represa Billings, D, 13.IV.2005, M.E.F.Rodrigues 23 (ESA). Represa Guarapiranga, EM12, 6.XI.2008, M.E.F.Rodrigues 454 (ESA).

58. Rhynchospora holoschoenoides (Rich.) Herter, Revista Sudamer. Bot. 9: 157. 1953.

Erva anfíbia, ereta, até $1 \mathrm{~m}$ alt., glabra. Maioria das folhas basais e 2-3 folhas caulinares, todas menores que caule, 1-2mm larg., lineares. Brácteas involucrais 1-2, menores que inflorescência, lineares. Inflorescência em antelas compostas, glomérulos globosos, formados pelas espiguetas sésseis, castanho-amareladas, ovais, dispostas em espiral. Aquênio lenticular, castanho, cerdas hipóginas. Distribuição na América tropical, África e Madagascar. Ocorre em todo território brasileiro, atingindo todos os biomas brasileiros. Na Represa Guarapiranga esteve presente nos pontos PA2 e EM12. Pode ser identificada pela inflorescência de antelas globosas com espiguetas dispostas em espiral e brácteas involucrais curtas.

Material examinado: Represa Billings, Q, 20.IV.2005, M.E.F.Rodrigues 46 (ESA). Represa Guarapiranga, GUA4, 10.X.2007, M.E.F.Rodrigues 271 (ESA).

59. Rhynchospora riparia (Nees) Boeckeler, Linnaea 37: 561.1873.

Fig.: $4 \mathrm{e}$

Erva anfíbia, ereta, $25 \mathrm{~cm}$ alt., cespitosa. Folhas geralmente maiores que o caule, 7-35x0,1$0,2 \mathrm{~cm}$, lineares, fortemente canaliculadas e rígidas. Bráctea involucral pouco maior que a inflorescência. Corimbos congestos, sendo 1 terminal e 1-3 axilares. Espiguetas em grupos de 2-9, oblongo-lanceoladas, castanho-avermelhadas, flores com 3 estames e 2 estigmas. Aquênios elipsóides, lenticulares, rugosos, castanho-enegrecidos. Distribuição na América do Sul. Ocorre em todo o território brasileiro, atingindo todos os biomas brasileiros. Na Represa Guarapiranga esteve presente nos pontos EG15, EG16 e EG17. Identificada pela inflorescência congesta, castanhoavermelhada e folhas canaliculadas e rígidas,1-2mm de larg.

\footnotetext{
Material examinado: Represa Guarapiranga, EG15,
7.I.2009, M.E.F.Rodrigues $532 \quad$ (ESA). Represa Guarapiranga, EG16, 4.XII.2008, M.E.F.Rodrigues 505 (ESA).
}

60. Scleria distans Poir., Encycl. (Lamarck) 7: 4. 1806.

Erva anfíbia, ereta, $30 \mathrm{~cm}$ alt. Folhas dispostas ao longo do caule, lâminas lineares, 7$14 \times 0,2-0,5 \mathrm{~cm}$, manchas púrpuras em ambas as faces, bainhas da parte basal com coloração púrpura. Inflorescência espiciforme, 3-7 espiguetas interrompidas em glomérulos, brácteas púrpuroesverdeadas, hirsutas, aristadas, flores unissexuais, 3 estames, estigma 3-fido. Aquênio subgloboso, rígido, branco, superfície rugosa. Distribuição na América e África tropicais e subtropicais. No Brasil ocorre em quase todos os estados, atingindo todos os biomas brasileiros. Na Represa Guarapiranga esteve presente apenas no ponto PA2. Pode ser identificada pela inflorescência e aquênios.

Material examinado: Represa Guarapiranga, PA2, 4.XII.2008, M.E.F.Rodrigues 525 (ESA).

\section{ERIOCAULACEAE} (2015)

Bibliografia: Amaral et al. (2008), Giulietti et al.

61. Syngonanthus caulescens (Poir.) Ruhland in Engl., Pflanzenr. IV (Heft 13): 267, f. 38. 1903.

Erva anfíbia, ereta, até $30 \mathrm{~cm}$ alt. Folhas simples, alternas espiraladas, sésseis, lâmina, 1,52,5×0,2-0,4cm, elípticas, glabras. Inflorescência em capítulos globosos cremes, localizados no ápice de numerosos escapos de comprimentos variados entre 6-16cm, envoltos por bráctea tubulosa, $1-2,5 \mathrm{~cm}$ compr., localizados em receptáculo de brácteas foliáceas e muitos tricomas filamentosos brancos, podem ocorrer brotamentos a partir desses receptáculos, sendo esses novos caules e receptáculos lanuginosos. Flores trímeras, cremes, menores que $2 \mathrm{~mm}$ diâm. Cápsula loculicida. Amplamente distribuída no Brasil, ocorre em quase todos os estados, atingindo Amazônia, Caatinga, Cerrado e Mata Atlântica. Na Represa Guarapiranga esteve presente apenas o ponto EM12. Pode ser identificada pela inflorescência muito característica de Eriocaulaceae.

Material examinado: Represa Guarapiranga, EM12,
7.I.2009, M.E.F.Rodrigues 535 (ESA). Represa
Guarapiranga, EM12, 16.X.2008, M.E.F.Rodrigues 427
(ESA).

\section{FABACEAE}

Bibliografia: Moreira (1997), Kissmann \& Groth (2000), Pott \& Pott (2000), Amaral et al., (2008). 
Chave para as espécies

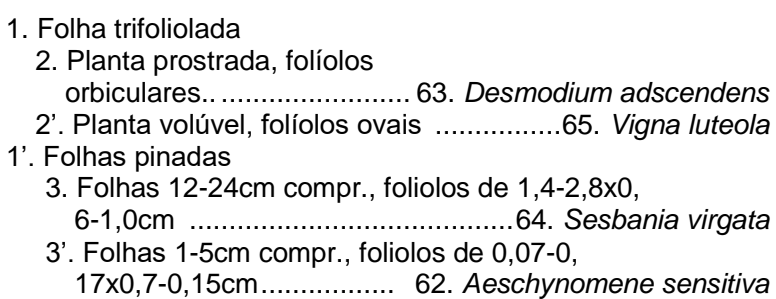

62. Aeschynomene sensitiva var. hispidula Rudd, Contr. U.S. Natl. Herb. 32(1): 54. 1955.

Arbusto anfíbio, ereto, emergente, até $3 \mathrm{~m}$ alt. caule densamente híspido-glandular. Folhas compostas, pinadas, $1-5 \mathrm{~cm}$ comp., pecioladas, estípulas peltadas, caducas, 8-21 pares de folíolos $0,07-0,17 \times 0,7-0,15 \mathrm{~cm}$. Panículas terminais, laxas. Flores 7-9mm compr., corola amarelo-amarronzada, nervuras vermelhas na pétala estandarte. Lomentos lineares, enegrecidos, 5-8 artículos indeiscentes. Distribuição na América tropical e África. No Brasil ocorre no Pará, Piauí, Minas Gerais e São Paulo atingindo Amazônia, Cerrado e Mata Atlântica. Desenvolve-se bem em solo coberto com lâmina de água, em local de plena insolação. Na Represa Guarapiranga esteve presente frequentemente nos pontos CC6, IT11-14 e raramente nos pontos PA2, EG16-18.

Material examinado: Represa Guarapiranga, EM14, 29.V.2008, M.E.F.Rodrigues 346 (ESA). Represa Guarapiranga, CC6, 29.V.2008, M.E.F.Rodrigues 350 (ESA). Represa Guarapiranga, 9G, 30.I.2007, M.E.F.Rodrigues 105 (ESA).

63. Desmodium adscendens (Sw.) DC., Prodr. 2: 332. 1825.

Erva, prostrada, parte terminal dos ramos ereta, $50 \mathrm{~cm}$ alt. Folhas compostas trifolioladas, alternas, pecíolo $0,5-1,3 \mathrm{~cm}$, folíolos, anterior 0,8 $1,7 \times 0,8-1,7 \mathrm{~cm}$, laterais $0,4-1,3 \times 0,4-1,1 \mathrm{~cm}$, membranáceos, face abaxial glabra e adaxial pubescente, obovado ou suborbicular, margem inteira. Inflorescência em racemos axilares e terminais, um par de pedicelos em cada nó, guarnecidos de uma bráctea ovalada e acuminada. Flores, 4-6mm compr., corola lilás ou lilás-rosada. Frutos em lomentos, 2-4 artículos, pardos e pubescentes com tricomas ferrugíneos. Distribuição na América tropical, Antilhas e África. Amplamente distribuído no Brasil, atingindo a Amazônia, Caatinga, Cerrado, Mata Atlântica e Pampa. Desenvolve-se em vários tipos de solos, mesmo áridos e secos, com temperatura elevada. $\mathrm{Na}$ Represa Guarapiranga foi encontrada nos pontos PA2 e EM12. Planta reconhecida pelo porte e inflorescência descrita acima.
Material examinado: Represa Guarapiranga, GUA4, 14.XII.2007, M.E.F.Rodrigues 320 (ESA). Represa Guarapiranga, PA2, 4.XII.2008, M.E.F.Rodrigues 515 (ESA).

64. Sesbania virgata (Cav.) Pers., Syn. PI. 2(2): 316. 1807.

Arbusto anfíbio, ereto, de $40-100 \mathrm{~cm}$ alt. Folhas compostas pinadas, $12-24 \mathrm{~cm}$ compr., alternas, pecíolo pubescente, estípulas lanceoladas, folíolos, de 10-24 pares, 1,4-2,8x0,6-1,0cm, membranáceos, glabros, elípticos, oblongos ou obovados. Inflorescência em racemos axilares, multifloros, pedúnculo e raque pubescentes. Flores curtopediceladas, corola amarela, estandarte orbicular, ápice emarginado e reflexo. Legumes indeiscentes, tetrágonos, corticosos e subarticulados. Distribuição na América do Sul. No Brasil ocorre nas regiões do Nordeste (AL, BA, PE, PB, PI e SE), Centro-Oeste, Sudeste e Sul, atingindo a Caatinga, Cerrado, Pantanal, Mata Atlântica, Pampa. Ocorre em locais muito úmidos ou alagados, frequentemente em solos modificados. Na Represa Guarapiranga esteve presente nos pontos RB5, CC6, CC8, IT9, EM13, EM14 e EG16. Identificado pelas folhas compostas geralmente com 16-18 pares de folíolos, flores amarelas, fruto indeiscente, corticoso, subarticulado.

Material examinado: Represa Guarapiranga, 6G, 19.I.2007, M.E.F.Rodrigues 88 (ESA). Represa Guarapiranga, 7G, 30.I.2007, M.E.F.Rodrigues 91 (ESA).

65. Vigna Iuteola (Jacq.) Benth. in Mart., FI. bras. 15(1B): 194. 1859.

Fig.: $4 f$

Erva anfíbia, volúvel, ramos pilosos. Folhas compostas trifolioladas, alternas, pecíolo 0,5-5,0cm compr., estípulas de base bilobada, folíolos basais 1,5$4,5 \times 1-3,2 \mathrm{~cm}$ e terminais 2-5,2x1-3,3cm, papiráceos, glabros ou esparso-pilosos, ovais a lanceolados, margem inteira. Inflorescência em racemos paucifloros axilares e terminais. Flores pediceladas, corola amarela, duas aurículas nas asas, estigma lateral. Legume maior que $4,5 \mathrm{~cm}$ compr. com no mínimo 5 sementes. Distribuição em toda região tropical. No Brasil está presente em todas as regiões geográficas, atingindo Amazônia, Caatinga, Cerrado e Mata Atlântica. Comum em beira de praia, restinga e margens de cursos d'água. Na Represa Guarapiranga foi encontrada nos pontos PA2 e EM12. Identificada pelas folhas compostas trifolioladas com folíolos ovais.

Material examinado: Represa Guarapiranga, EM12, 8.VII.2008, M.E.F.Rodrigues 370 (ESA). Represa Guarapiranga, GUA4, 10.X.2007, M.E.F.Rodrigues 270 (ESA). Represa Guarapiranga, EM12, 6.XI.2008, M.E.F.Rodrigues 449 (ESA) 
Levantamento de plantas aquáticas e palustres na represa Guarapiranga, São Paulo

\section{HALORAGACEAE}

Bibliografia: Kissmann \& Groth (2000), Amaral et al. (2008).

66. Myriophyllum aquaticum (Vell.) Verdc., Kew Bull. 28(1): 36. 1973.

Myriophyllum brasiliense Cambess., Fl. Bras. Merid. 2(15): 182. 1829[1830].

Pinheirinho-d'água.

Erva submersa fixa, rastejante a ascendente, emergente, muitos caules ramificados, tenros. Folhas simples, 4-6 verticiladas, sésseis, lâmina 1,5$2,5 \times 0,5 \mathrm{~cm}$, pinatissectas, constituídas de um eixo central e 6-18 segmentos laterais, nas submersas os segmentos são filiformes e avermelhados, nas emersas são lineares e glaucos. Flores solitárias, axilares, em ramos emergentes, unissexuadas, brancas. Nativa da América do Sul e introduzida na Austrália, Malásia, Japão, África do Sul e Oriental, América do Norte. No Brasil ocorrem no Nordeste (BA, AL, SE), Centro-Oeste (MS e MT), Sudeste e Sul, atingindo Cerrado, Pantanal, Mata Atlântica e Pampa. As melhores condições para o desenvolvimento são de água parada ou com fraca movimentação, elevado teor de nutrientes, especialmente nitrogênio, e temperaturas entre 8 e $30{ }^{\circ} \mathrm{C}$, frequentes em pequenos córregos, lagos, lagoas, solos encharcados. $\mathrm{Na}$ Represa Guarapiranga esteve presente de forma isolada ou bancos de poucos indivíduos nos pontos nos Braços Embu-Mirim e Parelheiros e em bancos de muitos indivíduos somente no Braço Embu-Guaçu. Facilmente identificada através das folhas pinatissectas e verticiladas oferecendo a planta uma aparência de pinheiro.

Material examinado: Represa Billings, A, 13.IV.2005, M.E.F.Rodrigues 1 (ESA). Represa Guarapiranga, GUA3, 3.V.2007, M.E.F.Rodrigues 131 (ESA). Represa Guarapiranga, GUA4, 14.XII.2007, M.E.F.Rodrigues 335 (ESA). Represa Guarapiranga, 7G, 30.I.2007, M.E.F.Rodrigues 92 (ESA).

\section{HYDROCHARITACEAE} (2002)

Bibliografia: Pott \& Pott (2000), Aona \& Amaral

\section{Chave para as espécies}

1. Folhas sésseis, verticiladas, margem serrilhada

1'. Folhas pediceladas, espiraladas, margem inteira 68. Limnobium laevigatum
67. Egeria densa Planch., Ann. Sci. Nat. Bot., sér. 3. 11: 80. 1849.

Elodea-brasileira, egeria, erva-d'água.

Erva submersa fixa, dioica, ereta ou prostrada, ramos tenros. Folhas simples, verticiladas, sésseis, lâmina 1,5-2×0,2-0,4cm, membranácea, tenra, glabra, linear, margem serrilhada. Inflorescência com espata axilar da qual saem 2-4 pedúnculos florais masculinos ou um pedúnculo floral feminino, que expõe as flores acima do nível da água. Flores unissexuadas, 3 sépalas, 3 pétalas brancas, flores masculinas com 9 estames, flores femininas com 3 estaminódios clavados, amarelos, estigma com 2-3 lobos irregulares amarelos. Fruto cápsula. Planta nativa amplamente distribuída pelo mundo por ser muito apreciada em aquário. No Brasil ocorrem no Nordeste (AL, BA, CE, PB e PE), Centro-Oeste (GO), Sudeste e Sul, atingindo Caatinga, Cerrado, Mata Atlântica e Pampa. Desenvolve-se bem em água doce numa faixa de 15 a $25^{\circ} \mathrm{C}$, tolerando uma ampla faixa de $\mathrm{pH}$. Na Represa Guarapiranga esteve dominante dos pontos PA1 ao PA4 em todo período de amostragem, esteve frequente nos pontos CC8-IT10, EM13-EG15 e EG20 e foi encontrada apenas uma vez nos pontos IT11-EM12, EG16 e EG19. No local de estudo estiveram presentes somente inviduos com flores pistiladas. Facilmente reconhecida por ser submersa fixa com folhas tenras, verticiladas e de margem serrilhada. Planta com grande desenvolvimento vegetativo em áreas eutrofizadas, sendo boa indicadora de ambientes poluídos.

Material examinado: Represa Guarapiranga, Não demarcou ponto, 29.V.2008, M.E.F.Rodrigues 345 (ESA). Represa Guarapiranga, GUA6, 19.IX.2007, M.E.F.Rodrigues 222 (ESA).

68. Limnobium laevigatum (Humb. \& Bonpl. ex Willd.) Heine, Adansonia, n.s. 8(3): 315. 1968.

Erva flutuante livre ou emergente, estolonífera, monoica. Folhas flutuantes, pecíolos curtos, $1-10 \mathrm{~cm}$ compr., lâminas, $2-3 \times 2,2-3 \mathrm{~cm}$ face abaxial convexa, inflada com tecido aerênquimatoso, face adaxial plana, orbiculares de margem inteira. Folhas emersas longo pecioladas, as duas faces planas, glabras, orbiculares a obovais. Flores unissexuadas, pediceladas, 3 sépalas, 3 pétalas na flor masculina, pétalas ausentes na flor feminina, estiletes longos, cremes. Fruto cápsula. Distribuição nas Américas Central e do Sul. No Brasil ocorre no Norte (AM, AP, PA), Nordeste (BA, MA, PE, PI), Centro-Oeste (MT, MS), Sudeste (MG, RJ, SP) e Sul (PR, RS), atingindo todos os biomas brasileiros. Adapta-se bem ao ambiente de aquário e tanques, mas necessita de muita luz, água de $\mathrm{pH}$ próximo ao neutro e com fundo de barro. Na Represa Guarapiranga foi encontrada somente na forma flutuante livre, vegetativa, nos pontos PA1-PA4, IT9 e EG15. Reconhecida pela folha flutuante com face abaxial esponjosa. 
Material examinado: Represa Guarapiranga, s.I., s.d., M.E.F.Rodrigues 566 (ESA).

\section{HYPERICACEAE}

Bibliografia: Bittrich (2003), Slusarski et al., (2007), Amaral et al. (2008).

\section{Chave para as espécies}

1. Erva a subarbusto, robusta, maior que

$50-100 \mathrm{~cm}$ 69. Hypericum brasiliense 1'. Erva delicada, $4-18 \mathrm{~cm}$ 70. Hypericum mutilum 1824.

69. Hypericum brasiliense Choisy, Prodr. 1: 547.

Erva a subarbusto anfíbio, ereto, até $1 \mathrm{~m}$ alt. Ramos verdes a vináceos. Folhas simples, opostas, sésseis, lâminas $0,5-1,7 \times 0,1-0,4 \mathrm{~cm}$, elípticas, glabras, glândulas diminutas, nervura central saliente na face abaxial. Inflorescência em dicásios terminais. Flores 5meras, pétalas amarelas a alaranjadas, muitos estames, pediceladas. Cápsula oval-cilíndrica a elíptica, maiores que sépalas, estigmas persistentes. Distribuição na Bolívia, Paraguai, Argentina e Brasil, no qual ocorre da Bahia ao Rio Grande do Sul, atingindo Cerrado, Mata Atlântica e Pampa. Desenvolve-se bem em áreas alagadas, mas pode ser encontrada também em mata, beira de mata e beira de estrada. Na Represa Guarapiranga esteve presente somente no ponto EM12 localizado em um parque estadual. Identificada pelas flores e cápsulas descritas acima.

Material examinado: Represa Guarapiranga, EM12, 16.X.2008, M.E.F.Rodrigues 424 (ESA).

70. Hypericum mutilum L., Sp. PI. 2: 787. 1753.

Erva anfíbia, ereta, $4-18 \mathrm{~cm}$ alt., caule quadrangular. Folhas simples, opostas, sésseis, sem estípulas, lâmina, 0,3-1,0×0,18-0,8cm, membranácea, glabra, glândulas na face abaxial, orbicular a oval, margem inteira. Inflorescência em dicásio, terminais, pedunculadas, 3-7 flores. Flores pediceladas, actinomorfas, 5 pétalas amarelas e 10 estames amarelos. Fruto cápsula com muitas sementes. Nativa das Américas, introduzida na Europa. No Brasil ocorre no Sudeste (MG e SP) e Sul, atingindo apenas a Mata Atlântica. A espécie está avaliada como "Vulnerável" na lista vermelha da flora de São Paulo (SMA-SP, 2004). Desenvolve-se bem em terrenos úmidos e alagados. Na Represa Guarapiranga esteve presente nos pontos IT11 e EG15. Reconhecida pela inflorescência em dicásio com flores amarelas e muitos estames.

\begin{abstract}
Material examinado: Represa Guarapiranga, EG15, 6.XI.2008, M.E.F.Rodrigues 443 (ESA). Represa Guarapiranga, IT11, 3.XII.2008, M.E.F.Rodrigues 469 (ESA, HUEFS).
\end{abstract}

\section{IRIDACEAE}

Bibliografia: Johnston (1938), Chukr \& Capellari Jr. (2003), Amaral et al. (2008).

\section{Chave para as espécies}

1. Folhas escamiformes, dispostas ao longo do caule .................................. 73. Sisyrinchium vaginatum

1'. Folhas não escamiformes, dispostas na

base da planta

2. Presença de uma bráctea tectriz no ápice do escapo plano ............. 71. Sisyrinchium commutatum

2'. Presença de diversas brácteas alternas ao escapo plano ............... 72. Sisyrinchium micranthum

71. Sisyrinchium commutatum Klatt, Hamburger Garten Blumenzeitung. 16: 164. 1860.

Fig.: $4 \mathrm{~g}$

Erva anfíbia, ereta, até $10 \mathrm{~cm}$ alt. Folhas basais, planas, lineares. Inflorescência em ripídio, 2-5 flores por planta, pedúnculos $1-2,5 \mathrm{~cm}$ compr., uma bráctea tectriz na base $0,5-2 \times 0,1 \mathrm{~cm}$, eretos, 2 brácteas florais, $0,4 \times 0,2 \mathrm{~cm}$, escapo $6,5 \times 0,1 \mathrm{~cm}$, plano, portando uma bráctea tectriz no ápice, plana. Flores com tépalas amarelas e nervuras vináceas, filetes totalmente concrescidos com tricomas em toda sua extensão, base tomentosa. Cápsulas globosas. Distribuição na América do Sul. No Brasil ocorre no Nordeste (BA), Centro-Oeste (GO, MS), Sudeste (MG, $\mathrm{SP}, \mathrm{RJ}$ ) e Sul (PR). Podem ser encontradas em campos abertos, alagados, gramados e beiras de mata. Na Represa Guarapiranga esteve presente de forma isolada apenas no ponto PA2 no Braço Rio Parelheiros. Identificada pela presença de apenas uma bráctea tectriz e filetes totalmente soldados com tricomas na região basal.

Material examinado: Represa Guarapiranga, GUA4, 9.XI.2007, M.E.F.Rodrigues 294 (ESA).

72. Sisyrinchium micranthum Cav., Diss. 6: 345 , tab. 191, fig 2. 1788.

Sisyrinchium laxum Otto ex Sims, Bot. Mag. 49: t. 2312. 1822.

Erva anfíbia, ereta, $5-45 \mathrm{~cm}$ alt. Folhas basais, 4-16x0,1-0,5cm, planas, linear-ensiformes. Inflorescência em ripídio, 2-6 por planta, pedúnculos 4$12 \times 0,1-0,3 \mathrm{~cm}$, escapo plano, $2,5-15 \times 0,1-0,4 \mathrm{~cm}$, 
Levantamento de plantas aquáticas e palustres na represa Guarapiranga, São Paulo

brácteas tectrizes alternas, planas, linear-ensiformes, 3-13,5x0,2-0,6cm, pedicelos, 2,5-4cm compr., glabros. Flores com tépalas brancas, amarelas ou lilases, tubo estaminal com uma porção livre, base tomentosa com tricomas capitados, hipanto globoso, pubescente. Cápsulas globosas pubescentes, sementes piramidais. Distribuição no México, América Central e América do Sul. No Brasil ocorre na região sudeste e sul, com exceção do Espírito Santo, atingindo a Mata Atlântica e Pampa. Pode ser encontrada em campos, matas ou áreas antropizadas. Na Represa Guarapiranga esteve presente com frequência nos pontos PA2, EG15, EG17 e apenas uma coleta nos pontos PA1, CC6, CC7, EG16, EG19 e EG20. Caracteriza-se por possuir folhas e escapos planos com brácteas tectrizes foliáceas e tubo estaminífero tomentoso na base. Foram encontradas plantas identificadas como $S$. laxum (Johnston, 1938), nos pontos PA2 e IT11 caracterizada pelas tépalas lilases e porte maior que S. micranthum, mas foi considerada sinônimo desta conforme Eggers (2015).

\begin{abstract}
Material examinado: Represa Guarapiranga, GUA4, 9.XI.2007, M.E.F.Rodrigues 293 (ESA). Represa Guarapiranga, PA2, 4.XII.2008, M.E.F.Rodrigues 520 (ESA). Represa Guarapiranga, IT11, 3.XII.2008, M.E.F.Rodrigues 468 (ESA). Represa Guarapiranga, EG15, 6.XI.2008, M.E.F.Rodrigues 548 (ESA). Represa Guarapiranga, GUA4, 9.XI.2007, M.E.F.Rodrigues 295 (ESA). Represa Guarapiranga, GUA4, 9.XI.2007, M.E.F.Rodrigues 301 (ESA). Represa Guarapiranga, GUA5, 10.X.2007, M.E.F.Rodrigues 234 (ESA). Represa Guarapiranga, GUA4, 9.XI.2007, M.E.F.Rodrigues 296 (ESA). Represa Guarapiranga, EG16, 4.XII.2008, M.E.F.Rodrigues 502 (ESA).
\end{abstract}

73. Sisyrinchium vaginatum Spreng., Syst. Veg. 1(3): 166. 1825.

Capim-trança, erva-cidreira.

Erva anfíbia, ereta, até $1 \mathrm{~m}$ alt., rizomatosa. Folhas escamiformes dispostas ao longo do caule ereto (também consideradas como brácteas tectrizes), planas, linear-ensiformes ou falciformes, 5-8,5x0,7$1,2 \mathrm{~cm}$, alternas dísticas. Inflorescência em ripídios, terminais, pedúnculos planos de $1,5-10 \mathrm{~cm}$ compr., brácteas florais carenadas, $2-4 \times 0,4-0,7 \mathrm{~cm}$. Flores com tépalas amarelas, estrias inconspícuas na base, filetes glabros, hipanto globoso, estiletes fundidos até metade do comprimento, porções superiores livres. Cápsula globosa, sementes globosas. No Brasil ocorre no Distrito Federal, São Paulo, Rio de Janeiro e no Sul, atingindo o Cerrado, Mata Atlântica e Pampa. Pode ser encontrada em cerrados, campos limpos, banhados, e campos com ação antrópica. Na Represa Guarapiranga esteve presente apenas no ponto EM12, um local de parque estadual. Caracterizada pela ausência de folhas basais, presença de folhas alternas entre si ao longo do caule, filetes soldados até metade do comprimento, glabros.

Material examinado: Represa Guarapiranga, EM12, 6.VIII.2008, M.E.F.Rodrigues 395 (ESA). Represa
Guarapiranga, EM12, 2.IX.2008, M.E.F.Rodrigues 408 (ESA). Represa Guarapiranga, EM12, 3.XII.2008, M.E.F.Rodrigues 475 (ESA). Represa Guarapiranga, EM12, 16.X.2008, M.E.F.Rodrigues 426 (ESA).

\section{JUNCACEAE}

Bibliografia: Balslev (1996), Kissmann \& Groth (2000), Luz (2004), Amaral et al. (2008).

74. Juncus microcephalus Kunth, Nov. Gen. Sp. (quarto ed.) 1: 237. 1815.

Erva anfíbia, ereta, $50-100 \mathrm{~cm}$ alt., cespitosa. Folhas basais ao escapo, bainhas membranáceas, lâminas, $8-30 \mathrm{~cm}$ compr. x 0,3-1cm diâm., circulares, ocas, septos transversais. Inflorescência terminal em dicásios ramificados, $5-20 \mathrm{~cm}$ compr., flores com 6 tépalas, lanceoladas, castanho-avermelhadas, 6 estames. Cápsulas obovoides, comprimento igual ou menor que perianto, muitas sementes. Distribuição na América Tropical. No Brasil ocorre nas regiões Nordeste (BA), Centro-Oeste (GO, MS), Sudeste e Sul, atingindo a Caatinga, Cerrado, Mata Atlântica e Pampa. Na Represa Guarapiranga esteve presente no ponto EM12. Espécie com muito polimorfismo, acorreram espécimes de $10-50 \mathrm{~cm}$ e 3 estames nos pontos EM14 e EG17 e espécimes com cápsula maior que tépalas e 3 estames no ponto PA2, sendo possíveis variedades de J. microcephalus. Pode ser diferenciada de Cyperaceae e Poaceae pela presença de perianto verdadeiro, sem presença de glumas e através dos frutos que são cápsulas deiscentes com muitas sementes.

\section{Material examinado: Represa Guarapiranga, EM14, 6.XI.2008, M.E.F.Rodrigues 539 (ESA). Represa Guarapiranga, PA2, 3.IX.2008, M.E.F.Rodrigues 414 (ESA, ICN). Represa Guarapiranga, EM12, 16.X.2008, M.E.F.Rodrigues 423 (ESA, ICN). Represa Guarapiranga, GUA4, 10.X.2007, M.E.F.Rodrigues 268 (ESA). Represa Guarapiranga, EM12, 6.XI.2008, M.E.F.Rodrigues 452 (ESA). Represa Guarapiranga, EM12, 3.XII.2008, M.E.F.Rodrigues 482 (ESA). Represa Guarapiranga, EG17, 4.XII.2008, M.E.F.Rodrigues 493 (ESA, ICN). Represa Guarapiranga, EM12, 6.XI.2008, M.E.F.Rodrigues 457 (ESA, ICN). Represa Guarapiranga, Marina Silvester, 10.X.2007, M.E.F.Rodrigues 282 (ESA, ICN).}

\section{LENTIBULARIACEAE}

Esta família é conhecida como carnívora, o gênero Utricularia possui estruturas diferenciadas, os utrículos, que são folhas modificadas em urnas que possuem glândulas secretoras de mucilagem que servem para atrair e depois capturar e digerir pequenos organismos aquáticos.

Bibliografia: Pott \& Pott (2000), Correa \& Mamede (2002), Amaral et al. (2008), Bove \& Paz (2009). 


\section{Chave para as espécies}

1. Planta com mais de $16 \mathrm{~cm}$, utrículos evidentes, estolão achatado com mucilagem ......75. Utricularia foliosa

1'. Planta com até $16 \mathrm{~cm}$, utrículos não evidentes, estolão circular sem mucilagem 76. Utricularia gibba

75. Utricularia foliosa L., Sp. PI. 1: 18. 1753. Lodo

Erva submersa fixa, estolões achatados, $50 \mathrm{~cm} \times 2 \mathrm{~mm}$, mucilaginosos. Folhas alternas, dicotomicamente ramificadas, segmentos filiformes no ápice, utrículos robustos na base dos segmentos foliares, pedicelados, globosos ou ovoides, escuros quando estão cheios de alimento. Inflorescência em racemos eretos, emersos, até 10 flores, escapo cilíndrico, arroxeado, glabro, mucilaginoso, pedicelos eretos nas flores e reflexos nos frutos, bráctea floral na base do pedicelo, oval, ápice truncado. Flores bissexuais, cálice 2-lobado sendo o inferior com o ápice 2 ou 3 dentado, corola amarela, nervuras púrpuras, lábio superior menor que inferior, ambos levemente bilobados, base com giba arredondada, calcar cônico. Cápsula globosa. Distribuição pantropical. Ampla ocorrência no Brasil, atingindo Amazônia, Caatinga, Cerrado, Pantanal e Mata Atlântica. Desenvolve-se bem em água parada ou pouco corrente, rasa ou profunda, em rios e alagados. $\mathrm{Na}$ Represa Guarapiranga esteve presente apenas nos pontos EG16 ao EG19, considerados oligotróficos. Pode ser identificada pelos utrículos robustos e estolões achatados e mucilaginosos.

Material examinado: Represa Billings, $O$, 20.IV.2005, M.E.F.Rodrigues 43 (ESA). Represa Billings, A, 13.IV.2005, M.E.F.Rodrigues 8 (ESA). Represa Guarapiranga, GUA3, 14.VI.2007, M.E.F.Rodrigues 199 (ESA). Represa Guarapiranga, GUA3, 14.VI.2007, M.E.F.Rodrigues 195 (ESA).

\section{Utricularia gibba L., Sp. PI. 1: 18. 1753.}

Erva submersa fixa, estolões delgados, 7$16 \mathrm{~cm}$ compr., secção circular, muito ramificados, formando um emaranhado na base da planta, sem mucilagem. Folhas pinatífidas, filiformes, muitos utrículos, opostos ou na axila dos segmentos foliares, sésseis, ovoides, enegrecidos quando repletos de alimento. Inflorescência em racemos eretos, geralmente com 3 flores, emersas, escapo filiforme, 27cm de compr., 2-16 pedicelos, eretos, filiformes, brácteas florais na base do pedicelo, semiamplexicaule. Flores bissexuais, cálice 2-lobado, ovais a orbiculares, corola amarela com nervura avermelhadas, lábio superior igual ou maior que o inferior, simples a trilobados, giba 2-lobada na base, calcar estreitamente cônico. Cápsula globosa. Distribuição pantropical. Ampla ocorrência no Brasil, atingindo Amazônia, Caatinga, Cerrado, Pantanal e Mata Atlântica. Cresce em áreas protegidas por vegetação, em água rasa, parada ou pouco corrente, ou na lama, não floresce até apoiar-se em baceiro ou material orgânico. Na Represa Guarapiranga esteve presente nos pontos EM12 e EM14, sendo ambos considerados palustres com nível da água variando muito. Pode ser identificada pela presença de utrículos e diferenciada de $U$. foliosa pelo porte e estolão de secção circular.

Material examinado: Represa Guarapiranga, EM12, 3.XII.2008, M.E.F.Rodrigues 489 (ESA). Represa Billings, C, 13.IV.2005, M.E.F.Rodrigues 13 (ESA). Represa Billings, A, 13.IV.2005, M.E.F.Rodrigues 6 (ESA). Represa Guarapiranga, EM14, 6.XI.2008, M.E.F.Rodrigues 460 (ESA).

\section{LINDERNIACEAE}

Bibliografia: Souza (1996), Souza (2003).

\section{Chave para as espécies}

1. Face abaxial da folha densamente glandulosopontuada, flores com pedicelos de 3-8mm compr. .......................................77. Lindernia rotundifolia

1'. Face abaxial da folha não ou pouco glandulosopontuada, flores sésseis ou com pedicelos menores que $1 \mathrm{~mm}$.............................78. Micranthemum umbrosum

77. Lindernia rotundifolia (L.) Alston, Handb. FI. Ceylon 6(Suppl., 2): 214. 1931.

Erva anfíbia, ascendente, $4-16 \mathrm{~cm}$ alt., emergente e anfíbia. Folhas opostas, sésseis, lâmina orbicular, 3-7mm diâm, glabra, margem inteira. Flores solitárias, terminais ou axilares, pedicelos $3-8 \mathrm{~mm}$ compr., zigomorfa, cálice e corola 5-meros, corola gamopétala, azul, lilás ou alva, pontuações azuis no lábio ventral, pilosa internamente, 2 estames, 2 estaminódios. Cápsula globosa com cálice persistente. Distribuição pantropical. No Brasil ocorre no Norte (AM, AC), Nordeste (AL, BA, CE, MA, PE), Centrooeste (DF), Sudeste (ES, RJ, SP) e Sul (PR, SC), atingindo Amazônia, Caatinga, Cerrado e Mata Atlântica. Encontradas em áreas abertas e alagáveis. $\mathrm{Na}$ Represa Guarapiranga esteve presente apenas uma vez nos pontos CC6, CC8, EG16, EG18 e frequentemente nos pontos PA1 e EM14. Pode ser identificada através das características da flor descritas acima.

Material examinado: Represa Billings, E, 13.IV.2005, M.E.F.Rodrigues 25 (ESA). Represa Guarapiranga, GUA4, 14.XII.2007, M.E.F.Rodrigues 334 (ESA). Represa Guarapiranga, GUA6, 19.IX.2007, M.E.F.Rodrigues 230 (ESA) 
Levantamento de plantas aquáticas e palustres na represa Guarapiranga, São Paulo

78. Micranthemum umbrosum (J.F. Gmel.) S.F. Blake, Rhodora 17(199): 131. 1915.

Erva anfíbia ou submersa enraizada, prostrada a ascendente, geralmente até $10 \mathrm{~cm}$ alt. Folhas simples, opostas, sésseis, lâminas, obovais, $0,3-1 \times 0,1-0,5 \mathrm{~cm}$, glabra, margem inteira. Flores axilares, inconspícuas, sésseis, cálice 4-mero, dialissépala, piloso na parte externa, corola 4-mera, gamopétala, alva, muito delgada, 2 estames fundidos na mesma pétala, ovário com placentação basal, pluriovulado. Cápsula globosa translúcida com muitas sementes. Distribuição na América do Sul. No Brasil ocorre no Norte (PA, AM), Nordeste (BA, CE, PB, PE), Centro-Oeste (MT), Sudeste (RJ, SP) e Sul (PR, SC, RS), atingindo Amazônia, Caatinga, Mata Atlântica e Pampa. A variedade das dimensões foliares e comprimentos dos internós dessa espécie podem estar relacionados a habitats com menor ou maior luminosidade e/ou umidade. $\mathrm{Na}$ Represa Guarapiranga esteve presente raramente nos pontos PA1, PA2, CC8, IT9 e EG18 e mais frequente nos pontos EG16 e EG17. Possível identificar pelas flores ou frutos inconspícuos presentes na axila de cada folha.

Material examinado: Represa Guarapiranga, EG16, 6.VIII.2008, M.E.F.Rodrigues 400 (ESA). Represa Guarapiranga, GUA3, 14.VI.2007, M.E.F.Rodrigues 196 (ESA). Represa Guarapiranga, CC6, 2.IX.2008, M.E.F.Rodrigues 433 (ESA).

\section{LYTRACEAE}

Bibliografia: Cavalcanti \& Graham (2007), Amaral et al. (2008), Cavalcanti \& Graham (2016).

79. Cuphea carthagenensis (Jacq.) J.F. Macbr., Publ. Field Mus. Nat. Hist., Bot. Ser. 8(2): 124. 1930.

Erva anfíbia, ereta, $8-50 \mathrm{~cm}$ alt., ramos com tricomas longos e glandulares. Folhas opostas, pecíolos 3-7mm compr., lâminas elípticas, 1,5-4,5×0,6$1,8 \mathrm{~mm}$, escabras a estrigosas, tricomas escabros nas nervuras, margem inteira a repanda, nervação camptódroma. Inflorescência em racemos axilares. Flores zigomorfas, curto-pediceladas, cálice gamossépalo, esverdeado a pardo, tricomas longos e glandulares, calcar diminuto, deflexo, pétalas 6 desiguais, livres, róseas a magenta, estames inseridos no tubo floral, 6 óvulos. Cápsula com 6 sementes de margem afinada e ala tênue. Distribuição na América Central e Norte. Ampla ocorrência no Brasil atingindo todos os biomas brasileiros. É freqüente em locais úmidos em solos com boa fertilidade. Na Represa Guarapiranga esteve presente raramente nos pontos CC6, IT10, EG16, EG17 e EG19 e frequentemente nos pontos PA2 e EM13 ao EG15. Pode ser identificada pelos tubos florais com 6 pétalas livres róseas e planta com muitos tricomas longos e glandulares.

Material examinado: Represa Guarapiranga, GUA5, 19.IX.2007, M.E.F.Rodrigues 211 (ESA). Represa Guarapiranga, EG15, 6.XI.2008, M.E.F.Rodrigues 549 (ESA). Represa Guarapiranga, Marina Silvester, 10.X.2007, M.E.F.Rodrigues 284 (ESA). Represa Guarapiranga, GUA5, 10.X.2007, M.E.F.Rodrigues 241 (ESA). Represa Guarapiranga, EM14, 6.XI.2008, M.E.F.Rodrigues 544 (ESA).

\section{MELASTOMATACEAE}

Bibliografia: Amaral et al. (2008), Guimarães (2009), Kriebel \& Rocha (2016).

Chave para as espécies

1. Ovário glabro

80. Acisanthera variabilis

1'. Ovário piloso no ápice 81. Tibouchina herbácea

80. Acisanthera variabilis (DC.) Triana, Trans. Linn. Soc. London 28: 34, pl. 11, f. 18g. 1871.

Subarbusto anfíbio, ereto, $80 \mathrm{~cm}$ alt., ramos quadrangulares, hirsutos com tricomas glandulares. Folhas opostas, subsésseis, lâminas ovais, ápice lanceolado, base arredondada a cordada, 0,7-1,5x0,6$1 \mathrm{~cm}$, hirsutas nas duas faces, margem serrilhada, nervuras acródromas. Inflorescência em tirsóides terminais, bracteada, $20-27 \mathrm{~cm}$ compr., pedúnculo 0,5$1,5 \mathrm{~mm}$ compr., hirsuto-glandular, pedicelo $1 \mathrm{~mm}$ compr., hipanto hirsuto-glandular, sépalas lineares hirsuto-glandulares, pétalas obovais, róseas a magenta, 10 estames, anteras com ápice atenuado, conectivo distintamente prolongado abaixo das tecas e ventralmente bilobado; ovário 3-locular. Fruto cápsula. Amplamente distribuída no Brasil, ocorrência do Nordeste ao Sul, atingindo a Caatinga, Cerrado e Mata Atlântica. Encontrada em ambiente alagado. $\mathrm{Na}$ Represa Guarapiranga esteve presente apenas no ponto EM12. Pode ser identificada pela nervura acródroma e presença de muitos tricomas glandulares por toda planta. Em Guimarães (2009) consta na chave e descrição como tendo face adaxial glabra o que difere da descrição de Amaral et al. (2008) e dos espécimes aqui analisados.

Material examinado: Represa Guarapiranga, EM12, 6.XI.2008, M.E.F.Rodrigues 000448A (ESA).

81. Tibouchina herbacea (DC.) Cogn. in Mart., FI. bras. 14(3): 408. 1885.

Arbusto anfíbio, ereto, $1 \mathrm{~m}$ alt., ramos quadrangulares, alados, tomentoso com alguns tricomas glandulares. Folhas opostas, pecíolos 0,5$1 \mathrm{~cm}$ compr., tomentosos, lâminas elípticas, 1,5$5,5 \times 0,8-3,0 \mathrm{~cm}$, tomentosas, tricomas glandulares, 
margem serrilhada, nervuras acródromas. Inflorescência em dicásios terminais, $7-38 \mathrm{~cm}$ compr. Flores vistosas, 4-meras, pedicelo até $1 \mathrm{~mm}$ compr., hipanto púrpuro, glandular-piloso, sépalas triangulares, glandular-pilosas, persistentes, pétalas róseas a roxas, estames 8, anteras com ápice subulado, estames em dois ciclos com conectivos de mesmo compr. Cápsulas. No Brasil ocorre no Sudeste e Sul, atingindo apenas a Mata Atlântica. Localizada em beira de rio, terrenos alagados, entre pedras, terrenos de cultura. $\mathrm{Na}$ Represa Guarapiranga esteve presente nos pontos PA2 e EM12. Pode ser identificada pelo indumento tomentoso em toda planta e folhas com nervuras acródromas.

Material examinado: Represa Guarapiranga, EM12, 6.XI.2008, M.E.F.Rodrigues 000448B (ESA). Represa Guarapiranga, PA2, 7.VII.2008, M.E.F.Rodrigues 356 (ESA). Represa Guarapiranga, EM12, 8.VII.2008, M.E.F.Rodrigues 372 (ESA). Represa Guarapiranga, 9G, 30.I.2007, M.E.F.Rodrigues 101 (ESA).

\section{MENYANTHACEAE}

Bibliografia: Kissmann \& Groth (2000), Pott \& Pott (2000), Anderson \& Amaral (2005), Amaral et al. (2008), Bove \& Paz (2009), Tippery \& Les (2011).

82. Nymphoides humboldtiana (Kunh) Kuntze, Revis. Gen. PI. 2: 429. 1891.

Estrela-branca, soldanela-d'água, coraçãoflutuante.

Erva flutuante fixa. Folhas simples, alternas e pecioladas no rizoma, $2,5-10 \mathrm{~cm}$ compr., lâminas flutuantes, suborbiculares, $5-10 \mathrm{~cm}$ diâm., margem inteira, base cordada, face adaxial verde, face abaxial vináceo-avermelhada. Inflorescências fasciculadoumbeliformes, axilares, pedicelos de $1-7 \mathrm{~cm}$ compr. Flores com cálice 5-lobado, subcarnoso, ovallanceolado, corola 5-mera, branca, base amarela, margens intensamente fimbriadas, 5 estames, anteras longas que se destacam. Cápsulas ovoides guarnecidas pelo cálice. Distribuição neotropical. No Brasil ocorre em quase todo território nacional, com excessão apenas do Acre, atinge todos os biomas brasileiros. É uma planta comum em áreas de mananciais de água parada ou com pouca movimentação. Na Represa Guarapiranga esteve presente do ponto EM14 ao EG19. Facilmente identificada pela sua flor de corola branca com base amarela e de margem intensamente fimbriada. Quando vegetativa pode ser confundida com Nymphaea caerulea diferenciando-se através da ausência de nervuras reticulares evidentes e manchas negras na face abaxial presentes em Nymphaea caerulea. Até pouco tempo era identificada erroneamente como $N$. indica devido à falta de distinção morfológica (Amaral, 2015).
Material examinado: Represa Guarapiranga, GUA3, 3.V.2007, M.E.F.Rodrigues 125 (ESA)

\section{NYMPHAEACEAE} (2008)

Bibliografia: Feres \& Amaral (2003), Amaral et al.

83. Nymphaea caerulea Savigny, Ann. Mus. Natl. Hist. Nat. 1: 366-371. 1802.

Ninféia.

Erva flutuante fixa. Folhas orbiculares a suborbiculares, ápice arredondado, base cordada, margem inteira a sinuosa, $20-37 \times 15-36 \mathrm{~cm}$, glabra, venação reticulada evidente na face abaxial, face adaxial verde e abaxial verde a púrpura com manchas púrpuras a negras. Flores solitárias, vistosas, longopediceladas, sépalas coriáceas verdes, manchas púrpuras, lanceoladas, pétalas lilás-azulada, base amarela, lanceoladas, muitos estames petalóides e filiformes, apêndice azul e anteras amarelas, muitos carpelos unidos na base e livres no ápice. Cápsula submersa. Nativa da África do Sul. Foi naturalizada no Brasil ocorrendo da Bahia ao Rio Grande do Sul, atinge apenas a Caatinga e Mata Atlântica. Na Represa Guarapiranga esteve presente nos pontos EG16 ao EG19. Facilmente identificada pelas folhas grandes, orbiculares, flutuantes e flores vistosas com pétalas lilás-azuladas de base amarela.

Material examinado: Represa Billings, $U$, 11.V.2005, M.E.F.Rodrigues 56 (ESA). Represa Billings, 21.V.2007, M.E.F.Rodrigues 184 (ESA) Represa Guarapiranga, 3.V.2007, M.E.F.Rodrigues 123 (ESA).

\section{OCHNACEAE}

Bibliografia: Amaral et al. (2008), Bove \& Paz (2009).

\section{Sauvagesia erecta L., Sp. PI. 1: 203. 1753.}

Erva emergente, ereta, $10-45 \mathrm{~cm}$ alt., muito ramificada. Folhas alternas, pedicelos até $1 \mathrm{~mm}$ compr., estípulas evidentes, até $0,5 \mathrm{~cm}$ compr., laciniadas, lâminas elípticas, 1-2×0,4-0,9cm, glabras, margem serreada. Flores solitárias ou duas agrupadas, axilares, pêndulas, pedicelos $1 \mathrm{~cm}$ compr., 5-meras, sépalas lanceoladas, livres, persistentes, pétalas, rosas a alvas, base púrpura, livres, 2 ciclos de estaminódios, externos numerosos, filamentosos, ápice espessados, avermelhados, internos 5, petalóides, avermelhados na base, cobrindo estames e ovário. Cápsula ovoide. Distribuição pantropical em ambientes úmidos. Ocorre em todos estados do Brasil atingindo Amazônia, Caatinga, Cerrado e Mata Atlântica. Localizada em ambientes de solos úmidos e 
Levantamento de plantas aquáticas e palustres na represa Guarapiranga, São Paulo

arenosos, abertos, como bordas de florestas e banhados. Na Represa Guarapiranga esteve presente apenas no ponto PA2. Pode ser identificada pelas estípulas evidentes e laciniadas.

Material examinado: Represa Guarapiranga, GUA4, 9.XI.2007, M.E.F.Rodrigues 300 (ESA). Represa Guarapiranga, PA2, 4.XII.2008, M.E.F.Rodrigues 516 (ESA).

\section{ONAGRACEAE}

Bibliografia: Hoehne \& Munz (1947), Kissmann \& Groth (2000), Pott \& Pott (2000), Amaral et al. (2008).

\section{Chave para as espécies}

1.Plantas prostradas, ascendentes ou submersas

2. Ervas ascendentes com folhas submersas e

flutuantes 92. Ludwigia sp

2'. Ervas prostradas

3. Plantas hirsutas, folhas com múcron glandular no ápice ............................. 86. Ludwigia grandiflora

3'. Plantas glabras ou com tricomas curtos, folhas sem múcron glandular no ápice

4. Ramos floríferos glabros, folhas menores que $1 \mathrm{~cm}$ de compr. .......91. Ludwigia peploides subsp. peploides

4'. Ramos floríferos pilosos, folhas maiores que $3 \mathrm{~cm}$ de compr. .. 90. Ludwigia peploides subsp. montevidensis

1'. Plantas eretas ou emersas

5. Plantas glabras

6. Folhas coriáceas, lanceoladas a largo-ovadas, nervuras laterais 20-30, evidentes 85. Ludwigia elegans

6 '.Folhas membranáceas, lineares, nervuras laterais

8-10, pouco evidentes .............88. Ludwigia longifolia

5'. Plantas com indumento

7. Sementes envoltas pelo endocarpo, flores pentâmeras ................................ 87. Ludwigia leptocarpa

7'.Sementes não envoltas pelo endocarpo, flores

tetrâmeras 89. Ludwigia octovalvis

85. Ludwigia elegans (Cambess.) H.Hara, J. Jap. Bot. 28(10): 292. 1953.

Erva a subarbusto anfíbio, ereto, $90 \mathrm{~cm}$ alt., sem ramificações. Folhas simples, alternas, pecíolos curtos $0,5-1 \mathrm{~cm}$ compr., estípulas inconspícuas, lâminas lanceoladas a largo ovadas, 6-10x2,5-3,3cm, coriáceas, glabras, mais de 20 nervuras secundárias vistosas e paralelas ligadas por venulações mais finas e também paralelas entre si, margens repandas. Flores solitárias axilares no ápice da planta, 4-meras, pétalas obovadas, amarelas, 8 estames subiguais. Cápsula obpiramidal, 4-angular, ápice umbonado. Distribuição na América do Sul. No Brasil ocorre no Centro-Oeste, Sudeste e Sul atingindo Cerrado, Pantanal e Mata Atlântica. Geralmente encontradas em locais úmidos ou alagados. $\mathrm{Na}$ Represa Guarapiranga esteve presente apenas no ponto EM12. Pode ser diferenciada das demais espécies do mesmo gênero através das características foliares.
Material examinado: Represa Billings, ponto 4 (transecto), 30.V.2007, M.E.F.Rodrigues 188 (ESA). Represa Guarapiranga, EM12, 3.XII.2008, M.E.F.Rodrigues 474 (ESA). Represa Billings, D, 13.IV.2005, M.E.F.Rodrigues 16 (ESA).

86. Ludwigia grandiflora (Michx.) Greuter \& Burdet, Fl. Bor.-Amer. 1: 267. 1803.

Fig.: $4 \mathrm{j}$

Erva emergente, ereta ou prostrada, $42 \mathrm{~cm}$ compr., ramos pilosos a seríceos. Folhas simples, alternas, sésseis a curto pecioladas, estípulas negras, lâminas, lanceoladas, $\quad 0,7-5,5 \times 0,3-1 \mathrm{~cm}$, múcron glandular no ápice. Flores solitárias axilares, 5-meras, pétalas $1,5 \times 1 \mathrm{~cm}$, amarelas, 8 estames iguais, anteras elípticas. Fruto cápsula. Distribuição no Continente Americano. $\mathrm{Na}$ Lista da Flora do Brasil consta ocorrência apenas no PR e SC (Vieira, 2015), mas segundo Vieira (com. pess.,2010) será adicionado o estado de São Paulo, atingindo apenas a Mata Atlântica. $\mathrm{Na}$ Represa Guarapiranga ocorreu raramente nos pontos PA2 e EM12. Espécie muito polimorfa pode ser diferenciada das demais espécies do mesmo gênero através do múcron glandular no ápice da folha.

Material examinado: Represa Guarapiranga, EM12,
3.XII.2008, M.E.F.Rodrigues 486 (ESA). Represa
Guarapiranga, GUA4, 14.XII.2007, M.E.F.Rodrigues 321
(ESA).

87. Ludwigia leptocarpa (Nutt.) H.Hara, J. Jap. Bot. 28(10): 292. 1953.

Cruz-de-malta, florzeiro.

Arbusto emergente, ereto, até $2 \mathrm{~m}$ alt., muito ramificada, ás vezes ramos violáceos e hirsutos no ápice. Folhas simples, alternas, estípulas inconspícuas, sésseis ou com base do limbo atenuado, lâminas lanceoladas, $3-9 \times 1-2,5 \mathrm{~cm}$, pode ter manchas púrpuras. Flores solitárias axilares, pedicelos $1-15 \mathrm{~mm}$ compr., 5 -meras, pétalas amarelas, $5-10 \mathrm{~mm}$ compr., 10 estames desiguais, estigma capitado. Cápsula subcilíndrica, reta ou curvada, $3-4 \mathrm{~cm}$ compr., violáceas a púrpuras, sementes livres, unisseriadas por lóculo e envoltas pelo endocarpo em forma de ferradura. Distribuição no Continente Americano e África. Ocorre na maioria dos estados do Brasil, atingindo a Amazônia, Caatinga, Cerrado, Pantanal e Mata Atlântica. Pode se desenvolver nas margens de coleções de água, ficando com um porte menor, ou se desenvolve em meio a massas flutuantes de outras plantas, os ramos atingem maiores comprimentos nessa condição. Na Represa Guarapiranga esteve presente nos pontos PA2, IT10, IT11, EG15 e EG17. É diferenciada das demais espécies do mesmo gênero pelas flores pentâmeras e sementes com endocarpo em forma de ferradura.

Material examinado: Represa Guarapiranga, EG15, 8.VII.2008, M.E.F.Rodrigues 381 (ESA). Represa 
Guarapiranga, 9G, 30.I.2007, M.E.F.Rodrigues 99 (ESA, FUEL). Represa Billings, 1B, 29.XI.2006, M.E.F.Rodrigues 68 (ESA). Represa Billings, T, 11.V.2005, M.E.F.Rodrigues 53 (ESA) Represa Billings, R, 11.V.2005, M.E.F.Rodrigues 50 (ESA). Represa Paiva Castro, 1P, 26.III.2007, M.E.F.Rodrigues 108 (ESA). Represa Guarapiranga, PA2, 7.VII.2008, M.E.F.Rodrigues 359 (ESA). Represa Billings, F, 13.IV.2005, M.E.F.Rodrigues 27 (ESA).

88. Ludwigia Iongifolia (DC.) H.Hara, J. Jap. Bot. 28(10): 293. 1953.

Erva a arbusto anfíbio, ereto, até $2 \mathrm{~m}$ alt., caule avermelhado e costado. Folhas simples, alternas, sésseis, estípulas inconspícuas, lâminas, lineares, ápice atenuado, 8-20x0,5-1cm, glabras, nervuras avermelhadas. Flores solitárias, axilares, pediceladas, 4-meras, bractéolas 5-7mm compr., pétalas amarelas. Cápsula angulosa, enegrecida, sépalas persistentes avermelhadas, sementes elípticas, sem endocarpo. Distribuição na Região Meridional do Brasil, Uruguai, Paraguai e Nordeste da Argentina. No Brasil ocorre no Nordeste (BA), CentroOeste (DF, MS), Sudeste e Sul, atingindo Caatinga, Cerrado e Mata Atlântica. Desenvolve-se em locais úmidos ou alagados. $\mathrm{Na}$ represa Guarapiranga foi localizada no ponto EM12. Pode ser diferenciada das demais espécies do mesmo gênero pelas folhas longas e estreitas com nervuras avermelhadas.

Material examinado: Represa Guarapiranga, EM12, 6.XI.2008, M.E.F.Rodrigues 450 (ESA). Represa Guarapiranga, EM12, 3.XII.2008, M.E.F.Rodrigues 477 (ESA, FUEL).

89. Ludwigia octovalvis (Jacq.) P.H.Raven, Kew Bull. 15: 476, f. 6d-e, 8h. 1962.

Subarbusto a arbusto emergente, ereto, até $2 \mathrm{~m}$ alt., ramos novos verde-avermelhados, pilosos a pubescentes. Folhas simples, alternas, subsésseis a curtamente pecioladas, lâmina elíptica ou lanceoladoovalada, 2-7x1,3-2,5cm, pilosas a hirsutas. Flores solitárias, axilares no ápice dos ramos, hipanto cilíndrico, pubescente, cálice e corola 4-mera, pétalas amarelas com nervuras aparentes, 8 estames. Cápsula cilíndrica, atenuada na base e ápice truncado, 2-5cm compr., pubescente, castanho-avermelhada, sementes livres, esféricas, rafe de diâmetro igual ao da semente. Amplamente distribuída em regiões de clima tropical e subtropical. No Brasil ocorre na maioria dos estados, atingindo Amazônia, Caatinga, Cerrado, Pantanal e Mata Atlântica. Localiza-se em locais úmidos como valas, baixadas, margens de coleções de água. Na Represa Guarapiranga esteve presente do ponto IT10 ao EM14 e no EG17. Pode ser diferenciada das outras plantas do mesmo gênero pelas sementes esféricas, sem endocarpo e com rafe de diâmetro igual ao da semente. A planta se assemelha muito a $L$. leptocarpa da qual pode ser diferenciada através do número de pétalas e sépalas, sendo 4 em L. octovalvis e 5-6 em $L$. leptocarpa.

Material examinado: Represa Guarapiranga, GUA5, 10.X.2007, M.E.F.Rodrigues 231 (ESA). Represa Guarapiranga, GUA6, 10.X.2007, M.E.F.Rodrigues 246 (ESA). Represa Guarapiranga, GUA6, 10.X.2007, M.E.F.Rodrigues 248 (ESA). Represa Guarapiranga, GUA5, 19.IX.2007, M.E.F.Rodrigues 207 (ESA). Represa Billings, ponto 4 (transecto), 30.V.2007, M.E.F.Rodrigues 189 (ESA). Represa Guarapiranga, EM13, 2.IX.2008, M.E.F.Rodrigues 404 (ESA, FUEL). Represa Guarapiranga, EM13, 6.VIII.2008, M.E.F.Rodrigues 399 (ESA, FUEL). Represa Guarapiranga, GUA6, 14.XII.2007, M.E.F.Rodrigues 329 (ESA).

90. Ludwigia peploides (Kunth) P.H.Raven, Reinwardtia 6(4): 393. 1963.

Erva emergente, prostrada, até $2 \mathrm{~m}$ compr. Folhas alternas, pecioladas, estípulas presentes. Planta glabra, lâminas obovais, $0,2-1 \times 0,1-0,3 \mathrm{~cm}$, curto-pecioladas. Flores solitárias, axilares, sésseis, 5meras, pétalas de coloração amarela intensa. Cápsulas cilíndricas, ápice truncado, sementes unisseriadas em cada lóculo. Distribuição cosmopolita. No Brasil possui ocorrência apenas para o Sul atingindo a Mata Atlântica, sendo este o primeiro registro desta espécie em São Paulo. Localiza-se em margem de coleções de água, podendo sobreviver sobre o solo limoso, desde que úmido. Na Represa Guarapiranga esteve presente nos pontos PA4, CC6, EG15. Diferencia-se das demais espécies do mesmo gênero através das cápsulas com sementes unisseriadas em cada lóculo.

Material examinado: Represa Guarapiranga, Marina Silvester, 10.X.2007, M.E.F.Rodrigues 285 (ESA). Represa Guarapiranga, GUA6, 19.IX.2007, M.E.F.Rodrigues 228 (ESA). Represa Guarapiranga, EG15, 6.XI.2008, M.E.F.Rodrigues 444 (ESA, FUEL).

Ocorreu outra subespécie de Ludwigia peploides conforme diferenciada abaixo:

91. Ludwigia peploides subsp. montevidensis (Spreng.) P.H.Raven, Reinwardtia 6(4): 395. 1963.

Fig.: $4 \mathrm{~h}$

Erva emergente com ramos floríferos pilosos, lâminas lanceoladas, 2-6,5×0,7-1cm, longo-pecioladas. Presente apenas uma vez no ponto PA2.

Material examinado: Represa Guarapiranga, GUA2, 14.XII.2007, M.E.F.Rodrigues 325 (ESA, FUEL).

\section{Ludwigia sp.}

$$
\text { Fig.: } 4 \text { I }
$$

Erva submersa fixa, ascendente, até $3 \mathrm{~m}$ compr. Folhas simples, alternas, estípulas negras, pecioladas, lâminas elípticas, verdes violáceas a marrom, folhas jovens em rosetas na axila das folhas 
Levantamento de plantas aquáticas e palustres na represa Guarapiranga, São Paulo

maduras. Na Represa Guarapiranga esteve presente apenas nos pontos do Braço Embu-Guaçu (EG16, EG17, EG18 e EG19). Apresentou apenas de forma vegetativa, motivo pelo qual não foi possível identificação da espécie e não foi depositada exsicata em herbário.

\section{ORCHIDACEAE}

Bibliografia: Batista et al. (2006)

93. Habenaria paulistana J.A.N.Bat. \& Bianch., Brittonia 58: 33. 2006.

Fig.: $4 \mathrm{~m}$

Erva anfíbia, ereta, 1,5m alt. Folhas até 12 caulinares, alternas, espaçadas, basais com bainha invaginante, lâminas lanceoladas, ápice atenuado, 10 $20 \times 1-3 \mathrm{~cm}$, apicais semelhantes às brácteas florais, elíptico-lanceoladas, ápice acuminado. Inflorescência em racemo, ereto, $22-35 \mathrm{~cm}$ compr., densifloro, brácteas florais elíptico-lanceoladas, ápice acuminado, menores que pedicelo e ovário. Flores vistosas, zigomorfas, longo-pediceladas, ovário indistinto, $3-7 \mathrm{~cm}$ diâm., sépalas verde-alvas, sépala dorsal oval a ovallanceolada, sépalas laterais deflexas, formando $180^{\circ}$ com a sépala dorsal, pétalas bipartidas, brancas na base e verde-claro a amarelo-esverdeado, labelo trilobado, não reflexos, esporão $11,5-13 \mathrm{~cm}$ compr., 2 polínias amarelas. Esta espécie foi descrita por Batista et al. (2006) como espécie endêmica do estado de São Paulo, atingindo apenas a Mata Atlântica. Na represa Guarapiranga esteve presente no ponto EM12, localizado no Parque Estadual da Guarapiranga. Pode ser facilmente identificada na represa pelas flores zigomorfas, verde-alvas presença de polínias.

Material examinado: Represa Guarapiranga, EM12, 6.XI.2008, M.E.F.Rodrigues 447 (ESA, BHCB).

\section{OROBANCHACEAE}

Bibliografia: Souza (1996), Souza (2003).

94. Agalinis communis (Cham. \& Schltdl.) D'Arcy, Ann. Missouri Bot. Gard. 65(2): 770. 1978.

Fig.: $5 a$

Erva a subarbusto anfíbio, ereto, $15-60 \mathrm{~cm}$ alt. Folhas opostas, sésseis, lâmina linear, 1-5x0,1-0,3cm, glabra, margem inteira, nervação hifódroma. Inflorescência em panícula, terminal, laxiflora. Flores axilares, pedicelo até $2 \mathrm{~mm}$ compr., glabro, cálice com lacínios lineares, 5-8mm compr., corola 5-mera, gamopétala, rósea com pontuações lilases e manchas amarelas na fauce, tubo piloso, lobos com ápice truncado e ciliado, 4 estames inclusos. Cápsulas elipsóides, muitas sementes, formatos irregulares, superfície brilhante e reticulada. Distribuição na América do Sul. No Brasil ocorre em São Paulo, Rio de Janeiro e no Sul, atingindo a Mata Atlântica e Pampa. Localiza-se em áreas abertas. $\mathrm{Na}$ Represa Guarapiranga esteve presente nos pontos PA2, EM14 e EG15. Pode ser identificada pelas folhas opostas, até $3 \mathrm{~mm}$ de larg. e nervação hifódroma.

Material examinado: Represa Guarapiranga, 9G, 30.I.2007, M.E.F.Rodrigues 104 (ESA). Represa Guarapiranga, GUA6, 10.X.2007, M.E.F.Rodrigues 247 (ESA). Represa Guarapiranga, PA2, 7.I.2009, M.E.F.Rodrigues 530 (ESA).

\section{PHRYMACEAE}

Bibliografia: Barroso (1952).

95. Mazus pumilus (Burm. f.) Steenis, Nova Guinea new series 9(1): 31. 1958.

Mazus japonicus (Thunb.) Kuntze, Revis. Gen. PI. 2: 462 .

Fig.: $5 b$

Erva anfíbia, ereta, $7 \mathrm{~cm}$ alt., pilosa. Folhas basais, opostas, sésseis, lâminas obovais, ápice arredondado, base acuminada amplexicaule, 1-3x0,3$1,8 \mathrm{~cm}$, glabras a pilosas na base, margem denteada. Inflorescência em ripídio, 2-10-flora. Flores alternas, pedicelo 0,3-1mm, piloso, bráctea presente, cálice gamosépalo, 5-mero, piloso, lacínios lanceolados, corola gamopétala, zigomorfa, bilabiada, lábio inferior com 2 lobos no ápice, menores que $1 \mathrm{~mm}$ compr., lineares, lábio superior 3-lobado, lobos arredondados, lilás no lado externo e branco no lado interno com manchas amarelas no lábio superior, 4 estames didínamos. Cápsula loculicida globosa. Distribuição na China, Austrália e Sudoeste da Ásia. Ocorre no Brasil de forma subespontânea. Na Represa Guarapiranga esteve presente nos pontos IT11 e EM14, considerados áreas frequentemente alagadas. Pode ser identificada pelas folhas basais obovais com a base acuminada semelhante ao pecíolo e através das características das flores. 

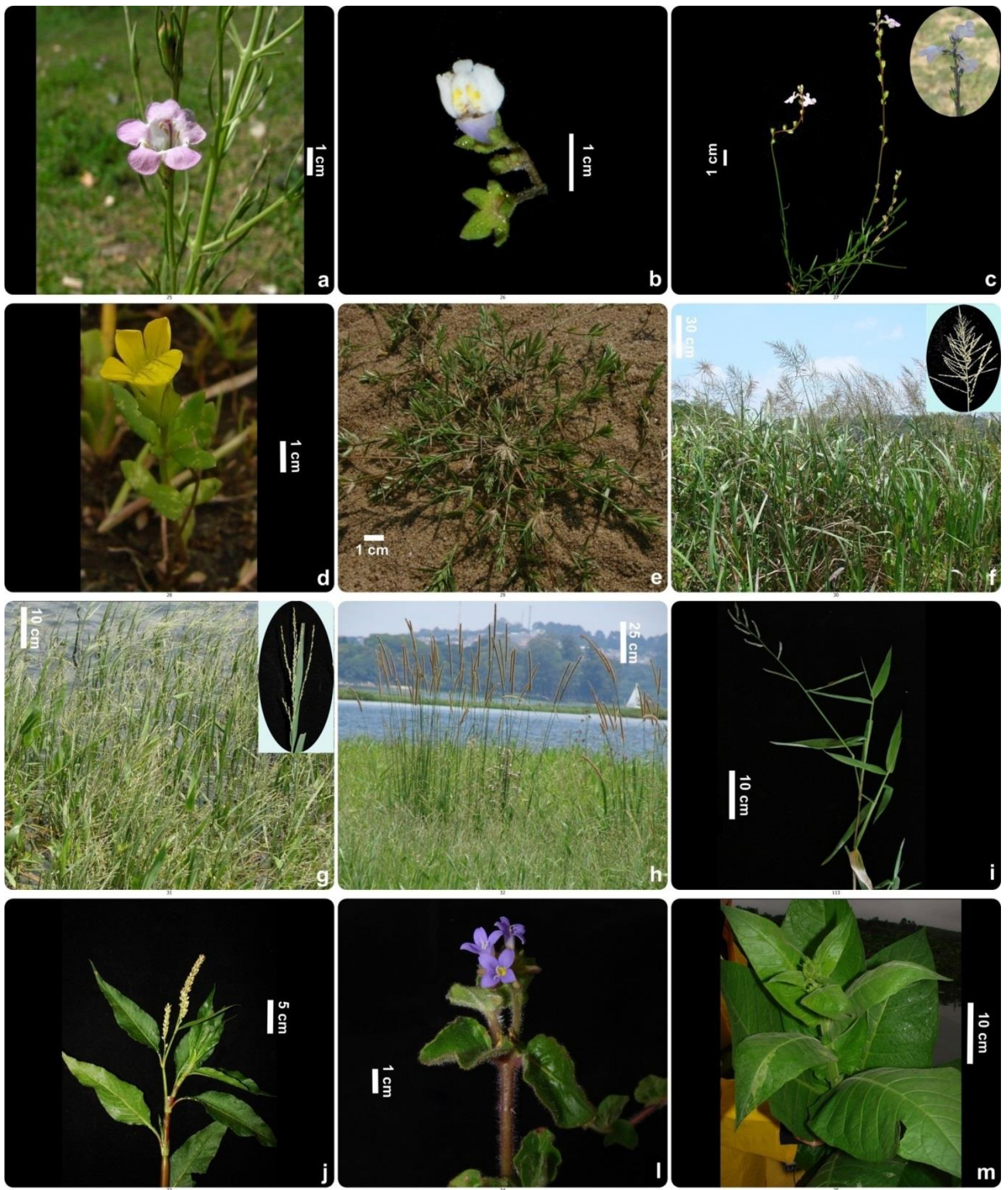

Fig. 5: Plantas aquáticas e palustres presentes na Represa Guarapiranga e não referidas em Amaral et al. (2008). a) Agalinis communis; b) Mazus pumilus; c) Nuttallanthus canadensis; d) Mecardonia procumbens var. caespitosa; e) Eragrostis hypnoides; f) Hymenachne pernambucense; g) Panicum repens; h) Setaria sphacelata; i) Urochloa arrecta j) Polygonum paraguayense; I) Coccocypselum capitatum; m) Nicotiana sp. 
Levantamento de plantas aquáticas e palustres na represa Guarapiranga, São Paulo

\begin{abstract}
Material examinado: Represa Guarapiranga, EM14, 6.XI.2008, M.E.F.Rodrigues 550 (ESA). Represa Guarapiranga, IT11, 3.XII.2008, M.E.F.Rodrigues 467 (ESA).
\end{abstract}

\section{PLANTAGINACEAE} (2003)

Bibliografia: Barroso (1952), Souza (1996), Souza

\section{Chave para as espécies}

1. Folhas orbiculares 96. Bacopa lanigera

1'. Folhas lanceoladas, elípticas ou lineares

2. Folhas verticiladas, lâminas lineares com larg. menor que $0,1 \mathrm{~cm}$..................... 98. Nuttallanthus canadensis

2'. Folhas opostas, lâminas não lineares com larg. maior que $0,1 \mathrm{~cm}$

3. Plantas com tricomas glandulares 97. Gratiola peruviana

3'. Plantas sem tricomas glandulares

4. Plantas maiores que $10 \mathrm{~cm}$ compr., hirsuta .............................100. Veronica javanica

4'. Plantas menores que $10 \mathrm{~cm}$, glabra a pilosa .99. Mecardonia procumbens

96. Bacopa Ianigera Wettst. in Engl. \& Prantl., Nat. Pflanzenfam. 4(3b): 77. 1891.

Erva anfíbia, prostrada, 15-35(54)cm, simples ou pouco ramificado, ramos hirsutos. Folhas opostas, sésseis, lâminas orbiculares, ápice e base arredondados, amplexicaule, 0,7-1,5x0,8-1,5cm, face adaxial glabra e abaxial pilosas com glândulas diminutas, margem inteira. Flores solitárias, axilares, longo-pediceladas, pedicelo de 1-2cm compr., hirsuto, 2 bractéolas lineares próximas ao cálice, cálice 4-mero com lacínios desiguais, 2 externos ovais com ápice agudo e base subcordada, internas lineares, ciliadohirsutas, gamopétala, zigomorfa, 5-mera, violáceas com fauce amarela, 4 estames, ovário com círculo de cerdas na base. Cápsula com sépalas persistentes cordadas. Espécie endêmica do Brasil ocorre em Minas Gerais, São Paulo, Rio de Janeiro e Rio Grande do Sul, atingindo apenas a Mata Atlântica. Desenvolve-se bem em áreas abertas e alagáveis. $\mathrm{Na}$ Represa Guarapiranga esteve presente nos pontos PA2 e EM12. Pode ser identificada através das folhas orbiculares, margem inteira e ramos hirsutos.

Material examinado: Represa Guarapiranga, EM12, 16.X.2008, M.E.F.Rodrigues 428 (ESA). Represa Guarapiranga, PA2, 4.XII.2008, M.E.F.Rodrigues 517 (ESA). Represa Guarapiranga, EM12, 6.XI.2008, M.E.F.Rodrigues 451 (ESA). Represa Guarapiranga, GUA4, 9.XI.2007, M.E.F.Rodrigues 302 (ESA).

\section{Gratiola peruviana L., Sp. PI. 1: 17. 1753.}

Erva anfíbia, ereta, $3 \mathrm{~cm}$ alt., glabra a esparsamente piloso-glandular. Folhas opostas, sésseis, lâminas, ovais a lanceoladas, ápice agudo, base subamplexicaule, $5 \times 3 \mathrm{~mm}$, glabras com muitas glândulas diminutas na face abaxial, margem serreada. Flores solitárias, terminais, 2 bractéolas linear-lanceoladas, cálice 5-mero, dialisépalo, lacínios subiguais, lanceolados, piloso-glandulares, corola, 5mera, gamopétala, alva, 3 estaminódios, 2 estames. Fruto não visto. Distribuição da Venezuela a Argentina e Chile. No Brasil ocorre em Minas Gerais, São Paulo, Rio de Janeiro e no Sul, atingindo a Mata Atlântica. Encontrada em áreas abertas e alagáveis. Na Represa Guarapiranga foi encontrada nos pontos IT11 e EM14, pontos caracterizados como alagados. Pode ser identificada pelo porte e presença de tricomas glandulares.

Material examinado: Represa Guarapiranga, IT11, 3.XII.2008, M.E.F.Rodrigues 470 (ESA).

98. Nuttallanthus canadensis (L.) D.A.Sutton, Revis. Antirrhineae 457. 1988.

Linaria canadensis (L.) Dum. Cours., Bot. Cult. 2: 96. 1802.

Fig.: $5 c$

Erva anfíbia, ereta, $20-60 \mathrm{~cm}$ alt., ramificadas na base, glabras. Folhas de ramos basais opostas ou verticiladas e do pedúnculo alternas, sésseis, lâmina linear, 0,5-2x0,1 cm, crassas, glabras, margem inteira. Inflorescência em racemo terminal, até $30 \mathrm{~cm}$ compr. Flores alternas, espaçadas, bráctea lanceolada 1, pedicelo 1-3mm compr., piloso, cálice 5-mero, dialissépalo, glabro a piloso, corola zigomorfa, bilabiada, personada, lábio inferior 3-lobado maior que superior 2-lobado, calcar de até $5 \mathrm{~mm}$ compr., lilás ou rosácea com parte inflada do lábio inferior branca, 4 estames didínamos, anteras biloculares. Cápsula poricida, 2 lóculos, numerosas sementes angulosas, rugosas. Distribuição América do Norte e do Sul. Naturalizada no Brasil ocorre no Rio de Janeiro, São Paulo e no Sul, atingindo a Mata Atlântica. Na Represa Guarapiranga esteve presente de forma isolada nos pontos RB5, IT9 e EG16. Pode ser facilmente identificada pelas características da flor descrita acima.

Material examinado: Represa Guarapiranga, Marina Silvester, 10.X.2007, M.E.F.Rodrigues 286 (ESA). Represa Guarapiranga, GUA5, 10.X.2007, M.E.F.Rodrigues 235 (ESA). Represa Guarapiranga, GUA5, 10.X.2007, M.E.F.Rodrigues 232 (ESA). Represa Guarapiranga, EG16, 4.XII.2008, M.E.F.Rodrigues 508 (ESA). Represa Guarapiranga, GUA4, 10.X.2007, M.E.F.Rodrigues 277 (ESA). Represa Guarapiranga, IT9, 3.XII.2008, M.E.F.Rodrigues 487 (ESA). 
99. Mecardonia procumbens var. caespitosa (Cham.) V.C.Souza, Acta Bot. Brasil. 11(2): 188. 1997. Fig.: $5 d$

Erva anfíbia, ereta, até $6 \mathrm{~cm}$ alt., glabra. Folhas opostas, curto-pecíoladas, pecíolo $1 \mathrm{~mm}$ compr., lâminas elípticas, ápice e base agudos, glabras, glândulas diminutas na face abaxial, margem serreada. Flores solitárias, axilares e terminais, pedicelo 3-7mm compr., cálice dialisépalo, 5-mero, lacínios externos elípticos e internos lineares, glabro, corola gamopétala, zigomorfa, 5-mera, amarela com nervuras violáceas, 4-5 estames. Cápsula ovoide com muitas sementes. Essa variedade é endêmica do Brasil com ocorrência apenas em São Paulo e região Sul, atingindo a Mata Atlântica e Pampa. Encontrada em áreas abertas e alagáveis. $\mathrm{Na}$ Represa Guarapiranga esteve presente nos pontos EM14 ao EG16 e EG19. Pode ser identificada através das flores amarelas com nervuras vinosa avermelhadas. Segundo Souza (2003) essa espécie pode chegar a $25 \mathrm{~cm}$ alt. e são procumbentes, no local estudado só foram encontradas até $6 \mathrm{~cm}$ e talvez por isso estivessem eretas.

Material examinado: Represa Guarapiranga, EG15, 7.I.2009, M.E.F.Rodrigues 536 (ESA). Represa Guarapiranga, EG16, 4.XII.2008, M.E.F.Rodrigues 503 (ESA)
100. Veronica javanica Blume, Bijdr. FI. Ned. Ind. 14: 742.1826.

Erva anfíbia, prostrada, maior que $20 \mathrm{~cm}$ alt., muito ramificada, ramos hirsutos. Folhas opostas, subsésseis, lâminas, ovais, $0,9-2,8 \times 1-2 \mathrm{~cm}$, glabras ou com tricomas nas nervuras, margem serreada. Inflorescência não vista. Infrutescência em racemos axilares, $3-7 \mathrm{~cm}$, pilosa, cálice 4-mero, diaslisépalo, lacínios elípticos, iguais. Cápsula cordada, ciliada, muitas sementes ovais, amarelas, translúcidas. Distribuição na Europa, Ásia temperada e África boreal. Naturalizada no Brasil ocorre no Sudeste (MG, RJ, SP) e Sul (RS), atingindo apenas a Mata Atlântica. $\mathrm{Na}$ Represa Guarapiranga esteve presente apenas no ponto IT10. Pode ser identificada através das cápsulas cordadas.

Material examinado: Represa Guarapiranga, GUA1, 14.XII.2007, M.E.F.Rodrigues 316 (ESA).

\section{POACEAE}

Bibliografia: Morrone \& Zuloaga (1992), Kissmann \& Groth (2000), Pott \& Pott (2000) Longhi-Wagner (2001).

1. Plantas com $4-19 \mathrm{~cm}$ alt., lâminas de $0,5-4 \mathrm{~cm}$ compr.

2. Plantas prostradas, panícula contraída 104. Eragrostis hypnoides

2'. Plantas eretas, panícula laxa 110. Reimarochloa acuta

1'. Plantas com mais de $28 \mathrm{~cm}$ alt., lâminas de $5-60 \mathrm{~cm}$ compr.

3. Lígula glabra

4. Lâmina com base cordado-amplexicaule, região do colo da bainha glabra

4'. Lâmina de base não cordado-amplexicaule, região do colo da bainha com tricomas

5. Lígula de 4-7,5mm compr., margem da lâmina escabra

5'. Lígula de 0,5-1,5mm compr., margem da lâmina glabra

6. Lâminas linear-lanceoladas, 0,2-0,6cm larg., inflorescência corimbiforme, brácteas da inflorescência presentes (espateólas)

6'. Lâminas lanceoladas, 1,5-1,8cm larg., panícula de ramos unilaterais contraídos, brácteas da inflorescência ausentes ……...............................................................107. Hymenachne pernambucense

3'. Lígula ciliada ou pilosa

7. Lígula pilosa, 2-3mm compr., inflorescência lanceolada em panícula com ramos unilaterais espiciformes, vermelho-violáceas ..........................................................................................103. Echinochloa polystachya

7'. Lígula ciliada, 0,4-2mm compr., inflorescência não-lanceolada em panículas espiciformes, típicas ou com ramos unilaterais contraídos, esverdeadas

8. Plantas decumbentes, lâminas linear-lanceoladas a lanceoladas de base subcordada, panícula de ramos unilaterais contraídos

9. Inflorescências com ramificações primárias alternas dísticas, ramificações secundárias ausentes

9'. Inflorescência com ramificações primárias alternas espiraladas, ramificações secundárias presentes

113. Urochloa arrecta

114. Urochloa mutica

8'. Plantas eretas, lâminas lineares a linear-lanceoladas (às vezes involutas) de base reta, panícula espiciforme, aberta ou típica, laxas

10. Lâminas ou margens escabras, panícula espiciforme, espiguetas rodeadas na base por um invólucro de cerdas 11. Colmo comprimido, bainhas basais flabeladas e quilhadas, panícula $10-39 \mathrm{~cm}$ compr., plantas 70-180 cm alt. ........................................................................................... 112. Setaria sphacelata 11'. Colmo cilíndrico, bainhas não flabeladas nem quilhadas, panícula 1,5-11cm compr., plantas 20$80 \mathrm{~cm}$ alt. 111. Setaria parviflora 10'. Lâminas glabras, panícula típica ou aberta, laxa, espiguetas sem cerdas na base 
Levantamento de plantas aquáticas e palustres na represa Guarapiranga, São Paulo

12. Panícula típica, laxa, espiguetas oblongas 2-flora

108. Panicum repens

12'. Panícula subaberta a aberta, laxa a subdensa, espiguetas lanceoladas 3-11-floras 105. Eragrostis mexicana 1753.

101. Andropogon bicornis L., Sp. PI. 2: 1046.

Capim-rabo-de-burro, capim-vassoura, macega.

Erva anfíbia, ereta, 1-2m alt., cespitosa. Folhas com bainhas glabras, lígulas curtas, truncadas, lâminas linear-lanceoladas, 0,2 a 0,6cm larg., glabras, rígidas, castanhas na maturação. Corimbos terminais ramificados, contraídos, ramos eretos e densamente agrupados, plumas esbranquiçadas e sedosas, compostas pelo agrupamento de três espiguetas, sendo 1 hermafrodita, 1 estéril e 1 masculina. Cariopse linear-lanceolada, castanho-escura. Distribuição no Continente Americano. Ocorre em todo território brasileiro, atingindo todos os biomas brasileiros. Encontrada em cerrado, campos e locais alterados. Na Represa Guarapiranga esteve presente nos pontos EM12, EG15 e EG16. Pode ser identificada pela inflorescência muito vistosa.

Material examinado: Represa Guarapiranga, EM12, 8.VII.2008, M.E.F.Rodrigues 385 (ESA, SP).

102. Echinochloa crus-galli (L.) P.Beauv., Ess. Agrostogr. 1: 53, 161, 169, pl. 11, f. 2. 1812.

Capim-arroz, canevão, barbudinho, capituva.

Erva emergente, ereta, 0,23-1,2m alt., cespitosa. Folhas com bainhas glabras, sem lígulas, lâminas linear-lanceoladas, $7-30 \times 0,5-1,2 \mathrm{~cm}$, glabras, margens escabras. Inflorescência com ramos unilaterais e espiciformes, lanceolada, ereta. Espiguetas lanceoladas, gluma superior verde a violácea, aristas de 4-6mm, antécio inferior estéril. Distribuição cosmopolita. Naturalizada no Brasil, ocorre em todas as regiões, atingindo todos os biomas brasileiros. Encontrada em campo aberto, margens de rios e em lavouras. Na Represa Guarapiranga esteve presente nos pontos PA1, CC6, IT9, EM12, EG15 e EG16. Espécie com grande polimorfismo, variando muito no porte e tamanho das estruturas, pode ser diferenciada de E. polystachya através da ausência de lígula e antécio inferior neutro.

Material examinado: Represa Guarapiranga, GUA2, 14.XII.2007, M.E.F.Rodrigues 323 (ESA). Represa Guarapiranga, EM12, 06.XI.2008, M.E.F.Rodrigues 459 (ESA). Represa Guarapiranga, EG15, 4.XII.2008, M.E.F.Rodrigues 509 (ESA). Represa Guarapiranga, PA1, 4.XII.2008, M.E.F.Rodrigues 523 (ESA, S). Represa Guarapiranga, EM12, 7.I.2009, M.E.F.Rodrigues 534 (ESA).

103. Echinochloa polystachya (Kunth) Hitchc., Contr. U.S. Natl. Herb. 22(3): 135. 1920.

Canarana, canarana-verdadeira, capim-capivara, capim-de-angola.
Erva emergente, ereta ou decumbente, até $2 m$ alt., cespitosa. Folhas com bainha glabra, violácea, lígula pilosa, 2-3mm compr., lâmina longamente acuminada, 20-36×1-2cm, escabrosa. Inflorescência panícula, de ramos unilaterais, espiciformes, piramidais, de $20-32 \mathrm{~cm}$ compr., ereta. Espigueta ovalada, gluma superior vermelho-violácea, arista de $6-7 \mathrm{~mm}$ compr., antécio inferior masculino. Amplamente distribuída no Continente Americano. No Brasil ocorre em todas as regiões, atingindo Amazônia, Caatinga, Cerrado, Pantanal e Mata Atlântica. Habita margens de rios e é invasora de várzeas de arroz. Na Represa Guarapiranga esteve presente nos pontos PA4, RB5 e IT9. Pode ser identificada pela presença de lígula pilosa e antécio inferior masculino.

Material examinado: Represa Guarapiranga, 124, 29.V.2008, M.E.F.Rodrigues 338 (ESA, SP).

104. Eragrostis hypnoides (Lam.) Britton, Sterns \& Poggenb., Prelim. Cat. 69. 1888.

Fig.: $5 \mathrm{e}$

Erva anfíbia, prostrada, $5-20 \mathrm{~cm}$ alt., estolonífera. Bainhas com tufos de tricomas laterais à região ligular, lígula pilosa, lâmina linear-lanceolada, 0,4-1,0x0,1-0,15cm. Inflorescência em panícula contraída, densa, curta, $1-1,5 \times 0,5-1,0 \mathrm{~cm}$, espiguetas esverdeadas, antécios imbricados. Cariopse castanhoclara. Distribuição da América do Sul até Canadá. Ocorre em todas as regiões do Brasil, atingindo Amazônia, Caatinga, Cerrado, Mata Atlântica e Pampa. Pode ser encontrada entre a vegetação rasteira nas dunas, margem úmida de lagos e rios, terrenos baixos e argilosos, área baixa de pastagem, margem seca de pântano e terra firme. Na Represa Guarapiranga esteve presente no ponto EM14. Pode ser identificada através do porte e tamanho das folhas.

Material examinado: Represa Guarapiranga, GUA5,
10.X.2007, M.E.F.Rodrigues 236 (ESA). Represa
Guarapiranga, EM14, 6.XI.2008, M.E.F.Rodrigues 542 (ESA).

105. Eragrostis mexicana (Hornem.) Link, Hort. Berol. 1: 190. 1827.

Erva emergente, ereta, 0,6-1m alt. Folhas com bainhas glabras, lígula membranoso-ciliada, lâmina linear, às vezes involuta, 10-26×0,1-0,3, glabra. Inflorescência em panícula aberta, laxa, 15-23x7$11 \mathrm{~cm}$, espiguetas lanceoladas, 3-11 floras, púrpuroesverdeadas, antécios imbricados, lemas com nervuras laterais evidentes caducas, páleas persistentes. Cariopse castanho-escura a avermelhada, sulco longitudinal ventral. Distribuição 
na América do Sul, América Central, México e Estados Unidos. No Brasil ocorre nas regiões Norte (TO), Nordeste (PE), Centro-Oeste (DF, MS), Sudeste (MG, RJ, SP) e Sul (PR, RS), atingindo Amazônia, Caatinga, Cerrado e Mata Atlântica. Encontrada em beira de caminho. Na Represa Guarapiranga esteve presente nos pontos EG15 e CC6. Pode ser identificada através da panícula típica laxa, púrpuroesverdeada.

Material examinado: Represa Guarapiranga, EG15, 5.VIII.2008, M.E.F.Rodrigues 387 (ESA, SP). Represa Guarapiranga, CC6, 5.VIII.2008, M.E.F.Rodrigues 386 (ESA). Represa Guarapiranga, CC6, 2.IX.2008, M.E.F.Rodrigues 410 (ESA). Represa Guarapiranga, CC6, 5.XI.2008, M.E.F.Rodrigues 441 (ESA).

106. Hymenachne amplexicaulis (Rudge) Nees, FI. Bras. Enum. PI. 2(1): 276. 1829.

Capim-capivara, capim-de-raposa, capim-caneta.

Erva emergente, decumbente, 0,8-1,5m compr. Folhas com bainhas glabras, lígulas membranáceas, 1-3mm compr., lâminas lanceoladas, planas, $11-42 \times 1,5-3 \mathrm{~cm}$, base cordado-amplexicaule, ápice atenuado, margens escabrosas. Inflorescência em panícula espiciforme, cilíndrica, compacta, 13$40 \mathrm{~cm}$ compr., espigueta lanceolado-acuminada, facilmente destacável, verde-pálida. Cariopse amarela. Distribuição do México a Argentina. No Brasil ocorre em todas as regiões, atingindo Amazônia, Caatinga, Cerrado, Pantanal e Mata Atlântica. Encontrada em cerrado, campos úmidos e borda de floresta. $\mathrm{Na}$ Represa Guarapiranga esteve presente na maioria dos pontos com exceção dos pontos IT10 e EG12. Facilmente identificada pela base da lâmina cordadoamplexicaule, lígula membranosa e panícula espiciforme cilíndrica.

\begin{abstract}
Material examinado: Represa Guarapiranga, PA1, 3.IX.2008, M.E.F.Rodrigues 417 (ESA). Represa Guarapiranga, 124, 29.V.2008, M.E.F.Rodrigues 341 (ESA). Represa Guarapiranga, PA1, 7.VII.2008, M.E.F.Rodrigues 354 (ESA, SP).
\end{abstract}

107. Hymenachne pernambucensis (Spreng.) Zuloaga, Amer. J. Bot. 90(5): 817. 2003.

Panicum pernambucense (Spreng.) Mez ex Pilg., Nat. Pflanzenfam. 14e: 15. 1940.

Panicum rivulare Trin., Gram. Panic. 213. 1826.

Capim-gigante-das-baixadas, capim-depernambuco.

Fig.: $5 f$

Erva emergente, ereta, $2 \mathrm{~m}$ alt., cespitosa. Folhas com bainha glabra ou hirsuta, violáceas, lígula membranosa sem longos tricomas, lâminas linearlanceoladas, ápice atenuado, base subcordada, 15$45 \times 0,5-1,5 \mathrm{~cm}$, glabras a pilosas, margens escabrosas. Inflorescência em panícula piramidal, ramos unilaterais contraídos, $36-45(64) \mathrm{cm}$, espiguetas elípticas, pediceladas, verde-violáceas. Cariopse oblonga, ocrácea. Distribuição na América do Sul. No Brasil ocorre no Norte (AM), Nordeste (BA, MA, PE), Centrooeste (GO, MT, MS), Sudeste e Sul, atingindo Amazônia, Caatinga, Cerrado e Mata Atlântica. Encontrada geralmente em campos baixos e banhados. Na Represa Guarapiranga esteve presente do ponto PA2 ao PA4, CC6 e do IT10 ao EG18. Pode ser identificada pela inflorescência piramidal verdeviolácea.

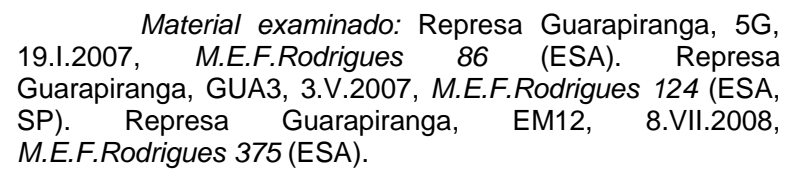

108. Panicum repens L., Sp. Pl. (ed. 2) 1: 87. 1762.

Capim-colonião, capim-colonia, capim-guine, capim-tanganica.

Fig.: $5 g$

Erva emergente, ereta, até $70 \mathrm{~cm}$ alt., rizomatosa. Bainhas sem lâminas na base da planta, e bainhas longas, lisas e glabras ao longo dos colmos, lígula membranoso-ciliada, lâminas linear-lanceoladas, acuminadas, $5-18 \times 0,1-0,6 \mathrm{~cm}$, planas ou involutas, rígidas, eretas, verde-pálidas. Inflorescência em panícula típica, laxa, 10-20cm compr., raque filiforme e pouco ondulada. Espiguetas oblongas, 2 floras, ápice acuminado, longo-pediceladas, isoladas, verde-pálidas com tons purpurescentes. Cariopse lanceolada, amarelo-palha. Amplamente distribuída em regiões tropicais e subtropicais. No Brasil é naturalizada com ampla ocorrência, atingindo Amazônia, Caatinga, Cerrado, Pantanal e Mata Atlântica. Encontrada em campo aberto e solos arenosos do litoral. Na Represa Guarapiranga esteve presente nos pontos CC6, CC7, IT10, IT11, EM12, EM14, EG15, EG16 e EG17. Pode ser identificada pelas folhas estreitas e eretas e pelas espiguetas comprimidas contra raque filiforme e pouco ondulada.

Material examinado: Represa Guarapiranga, EG15, 4.XII.2008, M.E.F.Rodrigues 511 (ESA). Represa Guarapiranga, CC6, 7.IV.2009, M.E.F.Rodrigues 555 (ESA). Represa Guarapiranga, 7G, 30.I.2007, M.E.F.Rodrigues 98 (ESA). Represa Guarapiranga, EG16, 6.VIII.2008, M.E.F.Rodrigues 389 (ESA). Represa Guarapiranga, EM12, 8.VII.2008, M.E.F.Rodrigues 377 (ESA). Represa Guarapiranga, EG15, 8.VII.2008, M.E.F.Rodrigues 382 (ESA). Represa Guarapiranga, EM12, 3.XII.2008, M.E.F.Rodrigues 481 (ESA, SP).

109. Paspalum urvillei Steud., Syn. PI. Glumac. 1: 24. 1855[1853].

Erva anfíbia, ereta, $1 \mathrm{~m}$ alt., cespitosa. Folhas com longas bainhas, glabras em cada nó, lígulas membranosas, longos tricomas atrás e lateralmente, 
lâminas linear-lanceoladas, ápice atenuado, 17$43 \times 0,8-1,5 \mathrm{~cm}$, margem escabrosa com porções crenuladas. Inflorescência em panículas eretas, ramos unilaterais espiciformes alternos, $20-28 \mathrm{~cm}$ compr., raque de $1 \mathrm{~mm}$ larg., espiguetas ovadas, pilosas, curtopediceladas, dispostas em 4 linhas. Cariopse elípticoovalada, plano-convexa, translúcida. Distribuição do Sul dos Estados Unidos até a Argentina. No Brasil ocorre na Bahia e em toda região Centro-Oeste, Sudeste e Sul, atingindo o Cerrado, Mata Atlântica e Pampa. Encontrada em locais antropizados e como invasora de culturas, preferindo solos úmidos. $\mathrm{Na}$ Represa Guarapiranga esteve presente apenas no ponto EM12. Pode ser identificada através da panícula com raque de $1 \mathrm{~mm}$ de larg. e as espiguetas dispostas em 4 linhas.

Material examinado: Represa Guarapiranga, EM12, 3.XII.2008, M.E.F.Rodrigues 483 (ESA).

110. Reimarochloa acuta (Fluggé) Hitchc., Contr. U.S. Natl. Herb. 12(6): 198. 1909.

Erva anfíbia, ereta, $20 \mathrm{~cm}$ alt., estolonífera Bainha glabra, lígula pilosa, lâmina linear-lanceolada, $2-5 \times 0,1-0,3 \mathrm{~cm}$, pilosas. Inflorescência em panícula aberta, laxa, 4-8x2-4cm. Espigueta oval-acuminada, 3$7 \times 0,5-1 \mathrm{~mm}$, verde a levemente violácea. Planta nativa do Brasil ocorrendo no Norte (PA, AM, TO), Nordeste (BA), Centro-Oeste e Sudeste (MG) atingindo a Amazônia, Caatinga, Pantanal e Cerrado. Até o presente estudo não havia registros para o estado de São Paulo. Encontrada em campo de várzea, cerrado (lato sensu) e vegetação aquática. $\mathrm{Na}$ Represa Guarapiranga esteve presente nos pontos PA1, EG15, EG16, EG17 e EG19. Possível identificar através do porte menor que demais espécies do mesmo gênero.

Material examinado: Represa Guarapiranga, EG16, 4.XII.2008, M.E.F.Rodrigues 000506A (ESA, SP).

111. Setaria parviflora (Poir.) Kerguélen, Lejeunia, n.s. 120: 161. 1987.

Setaria geniculata (Lam.) P. Beauv., Ess. Agrostogr. 51, 169, 178. 1812

Capim-rabo-de-gato, capim-rabo-de-raposa, rabo-de-quati, carrapicho-do-campo.

Erva anfíbia, ereta ou semi-prostrada, 17$80 \mathrm{~cm}$ alt., cespitosa. Folhas com bainhas glabras, lígula pilosa, lâminas linear-lanceoladas, 5-14x0,2$0,4 \mathrm{~cm}$, glabras, verde-claras, planas. Inflorescência em panícula espiciforme, cilíndrica, compacta, 1,5$11 \mathrm{~cm}$ compr., espiguetas elípticas, amareloesverdeadas, sésseis, 4-11 cerdas na base, amareladas ou purpuráceas, antrorso-escabrosas, as quais permanecem após queda da espigueta. Cariopse ovalada a elíptica, plano-convexo, verdeolivácea. Distribuição no Continente Americano. Ocorre amplamente em todas as regiões do Brasil, atingindo Amazônia, Caatinga, Cerrado, Pantanal e Mata Atlântica. Considerada invasora em áreas cultivadas, beira de caminhos, terrenos baldios, sendo encontrada também em campo natural de solos arenosos, secos e campos alagados. Na Represa Guarapiranga esteve presente nos pontos PA1, EG16 e EG19. Pode ser identificada através das características da inflorescência diferenciando-se de S. sphacelata pela ausência de bainhas flabeladas e quilhadas e porte menor que $80 \mathrm{~cm}$

Material examinado: Represa Guarapiranga, EG16, 4.XII.2008, M.E.F.Rodrigues 000506B (ESA). Represa Guarapiranga, GUA2, 14.XII.2007, M.E.F.Rodrigues 326 (ESA). Represa Guarapiranga, EG19, 4.XII.2008, M.E.F.Rodrigues 501 (ESA, SP).

112. Setaria sphacelata (Schumach.) Stapf \& C.E. Hubb. ex M.B. Moss, Kew Bull. (6): 195. 1929.

Fig.: $5 h$

Erva anfíbia, ereta, 1,5m alt., cespitosa. Folhas com bainhas basais flabeladas e quilhadas, purpuráceas ou esverdeadas, lígula membranosociliada, lâminas lineares, $17-25 \times 0,4-0,8 \mathrm{~cm}$, glabras, glaucas. Inflorescência em panícula espiciforme, cilíndrica, compacta, $10-24 \mathrm{~cm}$ compr., espiguetas elíptico-lanceoladas, verde-purpuráceas, sésseis, 5-9 cerdas na base, amareladas, antrorso-escabrosas, as quais permanecem após queda da espigueta. Distribuição em regiões tropicais, subtropicais e temperadas. No Brasil ocorre no Norte (AM, RR, RO), Nordeste (BA, PI), Sudeste (MG, RJ, SP) e Sul, atingindo Amazônia, Cerrado e Mata Atlântica. Encontrada em áreas de cultivo e escapada de cultivo. $\mathrm{Na}$ Represa Guarapiranga esteve presente nos pontos CC6 e IT9. Pode ser identificada pelas características da inflorescência e diferenciada de $S$. parviflora pela presença de bainhas flabeladas e quilhadas e porte maior que $80 \mathrm{~cm}$.

Material examinado: Represa Guarapiranga, CC6, 29.V.2008, M.E.F.Rodrigues 343 (ESA). Represa Guarapiranga, CC6, 19.II.2009, M.E.F.Rodrigues 551 (ESA).

113. Urochloa arrecta (Hack. ex T. Durand \& Schinz) Morrone \& Zuloaga, Darwiniana 31(1-4): 69. 1992.

Braquiária d’água.

Fig.: $5 \mathrm{i}$

Erva emergente, decumbente, 0,5-1,5m alt., estolonífera. Folhas com bainha glabra, basais frouxas, margem hialina, lígula membranoso-ciliada, lâminas lanceoladas, base subcordada, 5-15x0,7$1,5 \mathrm{~cm}$, glabras, margens escabrosas. Inflorescência em panícula, $9-19 \mathrm{~cm}$ compr., 4-9 ramos unilaterais contraídos e não ramificados, alternos e espaçados, raque de 1-2mm larg., espiguetas subsésseis, ovalado-elípticas, glabras, verde-clara a púrpuras, 
dispostas alternadamente em duas linhas. Cariopse raramente é formada. Planta nativa da África e introduzida no Brasil, Guiana Francesa e Venezuela. Naturalizada no Brasil ocorre no Norte (AM), Nordeste (BA, CE, MA, PB, PE), Centro-Oeste (GO, MS), Sudeste (MG, SP) e Sul (RS, SC), atingindo Amazônia, Caatinga, Cerrado e Mata Atlântica. Na Represa Guarapiranga esteve frequentemente nas margens dos pontos PA1, PA4, CC6 ao EM12 e EG15, ficando emergentes na época de cheia. Pode ser identificada pelas características da inflorescência, está geralmente associada com $U$. mutica da qual se diferencia por possuir apenas ramificações primárias.

Material examinado: Represa Guarapiranga, PA1, 4.XII.2008, M.E.F.Rodrigues 522 (ESA, SP). Represa Guarapiranga, 124, 29.V.2008, M.E.F.Rodrigues 339 (ESA). Represa Guarapiranga, EG15, 8.VII.2008, M.E.F.Rodrigues 383 (ESA). Represa Guarapiranga, IT11, 16.X.2008, M.E.F.Rodrigues 421 (ESA). Represa Guarapiranga, GUA6, 5.VII.2007, M.E.F.Rodrigues 202 (ESA).

114. Urochloa mutica (Forssk.) T.Q. Nguyen, Novosti Sist. Vyss. Rast. 13. 1966.

Brachiaria mutica (Forsk.) Stapf, Fl. Trop. Afr. 9: 526. 1919.

Capim-de-angola, capim-de-corte, capim-do-pará, capim-fino.

Erva emergente, decumbente a ascendente, 1-2(3)m alt., rizomatosa. Folhas com bainhas hirsutas a glabras, estriadas, verde-claras, lígula membranosociliada, lâminas linear-lanceoladas, 10-35×1-2cm, glabras a pilosas, base subcordada e ápice fortemente atenuado, margens cartilaginosas e escabrosas. Inflorescência em panícula piramidal, $10-25 \mathrm{~cm}$ compr., 10-30 ramos unilaterais contraídos e ramificados, alternos a subverticilados, ascendentes e divergentes, raque $0,4-0,9 \mathrm{~mm}$ larg., espiguetas ovais, glabras, verde a púrpuras, dispostas em 2-4 linhas, estigmas roxo ou negro, expostos durante a floração. Cariopse ovalada, amarelada. Nativa da África do Norte, introduzida e naturalizada no Continente Americano. No Brasil possui distribuição ampla em todas as regiões, atingindo Amazônia, Caatinga, Cerrado e Mata Atlântica. Subespontânea em locais antropizados e desenvolve-se bem em áreas alagadas. Na Represa Guarapiranga esteve presente nos pontos CC7 e CC8 em associação com $U$. arrecta da qual se diferencia pela panícula com ramos primários basais apresentando curtas ramificações secundárias.

Material examinado: Represa Guarapiranga, CC8 e CC7, 29 IV 2009, M.E.F.Rodrigues 560 (ESA, SP).

\section{POLYGONACEAE}

Bibliografia: Kissmann \& Groth (2000), Pott \& Pott (2000), Amaral et al (2008), Melo \& Marcondes Ferreira (2009), Melo (2016).

\section{Chave para as espécies}

1. Tirsos paniculados, congestos, fascículos espaçados, perigônio frutífero com alas triangulares de margens fimbriadas ou denteadas .............120. Rumex obtusifolius

1'. Tirsos racemosos, não congestos, sem fascículos, perigônio frutífero sem alas

2. Ramos e pedúnculos com tricomas glandulares ....................118. Polygonum paraguayense

2'. Ramos e pedúnculos sem tricomas glandulares

3. Frutos com pericarpo lenticular

4. Ócreas emersas pubescentes com longos tricomas setosos .........115. Polygonum acuminatum

4'. Ócreas emersas glabras ..................... 116. Polygonum ferrugineum

3'. Frutos com pericarpo trígono ou trígono-ovalado (eventualmente lenticular no mesmo indivíduo em P. hydropiperoides)

5. Planta com glândulas punctiformes, marrons reluzentes no perigônio frutífero ..........................119. Polygonum punctatum

5'. Plantas sem glândulas punctiformes visíveis ..................117. Polygonum hydropiperoides

115. Polygonum acuminatum Kunth, Nov. Gen. Sp. (quarto ed.) 2: 178. 1817.

Erva-de-bicho-peluda, fumo-bravo.

Erva emergente, decumbente a ascendente, até 1,5m compr., caule fistuloso, avermelhado, geralmente pubescente podendo ser glabra quando imersa. Folhas com ócreas muito desenvolvidas, coberta por longos tricomas amarronzados e longos cílios no ápice; lâmina elíptico-lanceolada, séssil ou subséssil, ligada ao caule pela base da ócrea, 10$15 \times 0,3-1,5 \mathrm{~cm}$, superfície velutina. Inflorescência espiciforme, espigas terminais e axilares, cilíndricas, compactas, até $10 \mathrm{~cm}$ de compr., alvas ou rosadas, pedúnculos pilosos de $0,5-5 \mathrm{~cm}$ compr. Flores com ocréolas ovadas, rosadas e longos cílios, perigônio 4-5 lobos, branco a rosado. Núcula lenticular, apiculada. Distribuição no Continente Americano. No Brasil ocorre em todas as regiões geográficas atingindo Amazônia, Caatinga, Cerrado, Pantanal e Mata Atlântica. Pode ser encontrada em margens de rios e lagoas de águas límpidas. Na Represa Guarapiranga esteve presente nos pontos EM12 e EG15. Pode ser identificada pelos longos tricomas marrom nas ócreas e pedúnculos.

Material examinado: Represa Guarapiranga, EM12, 6.VIII.2008, M.E.F.Rodrigues 396 (ESA). Represa Guarapiranga, EG15, 4.XII.2008, M.E.F.Rodrigues 513 (ESA, HUEFS).

116. Polygonum ferrugineum Wedd., Ann. Sci. Nat., Bot., sér. 3. 13: 252. 1849.

Polygonum spectabile Mart. ex Meisn. in Mart., FI. bras. 5(1): 13, pl. 3. 1855.

Erva-de-bicho-gigante, cataia-gigante, fumo-bravo.

Erva ou subarbusto emergente, decumbente ou ereto, 0,5-2m compr., caule cilíndrico e fistuloso. Folhas concentradas na parte superior, ócreas muito desenvolvidas, membranáceas, ferrugíneas, ápice 
truncado, poucos cílios decíduos, pecíolo fundido com a ócrea, 1-2cm compr., lâmina elíptico-lanceolada, base atenuada e ápice acuminado, $10-25 \times 2-5 \mathrm{~cm}$, glândulas puntiformes em ambas as faces, viscosa, face adaxial serícea quando jovem. Inflorescência em tirsos espiciformes, terminais e axilares, $2-8 \mathrm{~cm}$ compr., pedúnculos de $3,5-7 \mathrm{~cm}$ compr. Flores subsésseis, ocréolas glabras, glândulas esparsas, perigônio 4lobado, sempre fechado sobre órgãos reprodutores, rosado intenso a esbranquiçado. Núcula lenticular, faces convexas com cavidade central, de até $2,5 \mathrm{~mm}$ de compr. Distribuição na América do Sul. Amplamente distribuída em todas as regiões do Brasil, atinge Amazônia, Caatinga, Cerrado e Mata Atlântica. Encontrada em beira de lagoas, margens de rios e locais inundados. Na Represa Guarapiranga ocorreu constantemente e com abundância em todos os pontos, caracterizando-a assim como espécie dominante. Em Kissmann \& Groth (2000) há ilustração de infestação de $P$. lapathifolium na Represa Guarapiranga e a mesma espécie é citada em vários levantamentos realizados em reservatórios do estado de São Paulo (Tanaka et al., 2002; Carvalho et al., 2003; Cavenaghi et al., 2003; Carvalho et al., 2005; Cavenaghi et al., 2005; Martins et al., 2008; Martins et al., 2009), porém em Melo \& Marcondes Ferreira (2009) e Melo (2016) a espécie $P$. lapathifolium não é referida para o estado de São Paulo nem para o Brasil. Pode ser diferenciada das demais espécies do mesmo gênero pelo indumento velutino e branco das folhas jovens e pela ócrea glabra, ferrugínea, ápice truncado e sem longos tricomas.

Material examinado: Represa Guarapiranga, 3G, 19.I.2007, M.E.F.Rodrigues 83 (ESA). Represa Guarapiranga, GUA4, 3.V.2007, M.E.F.Rodrigues 126 (ESA, HUEFS). Represa Guarapiranga, PA4, 7.IV.2009, M.E.F.Rodrigues 553 (ESA). Represa Guarapiranga, CC7, 7.VII.2008, M.E.F.Rodrigues 364 (ESA, HUEFS). Represa Guarapiranga, EM14, 8.VII.2008, M.E.F.Rodrigues 368 (ESA). Represa Guarapiranga, CC6, 29.V.2008, M.E.F.Rodrigues 342 (ESA, HUEFS). Represa Guarapiranga, CC6, 7.VII.2008, M.E.F.Rodrigues 363 (ESA, HUEFS). Represa Guarapiranga, 124, 29.V.2008, M.E.F.Rodrigues 340 (ESA).

117. Polygonum hydropiperoides Michx., FI. Bor.-Amer. 1: 239. 1803.

Erva-de-bicho.

Erva emergente, decumbente a ereta, até $60 \mathrm{~cm}$ alt., geralmente de coloração vinosa. Folhas com ócrea cilíndrica de tricomas no ápice, pecíolo de 3-5mm compr., lâmina linear-lanceolada, 4-12x0,5$1,5 \mathrm{~cm}$, estrigosa, verde com pigmentação púrpura, glândulas brancas e opacas na face abaxial. Inflorescência em pleiotirsos, laxos, tirsos delgados de até $6 \mathrm{~cm}$ compr. Flores com ocréolas glabras, ápice ciliado, sem glândulas, perigônio 5-lobado, esverdeado ou rosa intenso. Núcula trígona-ovalada e lenticular no mesmo espécime. Ampla distribuição no Continente Americano. No Brasil ocorre no Norte (AP,
RR, TO) e amplamente do Nordeste e do CentroOeste ao Sul, atingindo Caatinga, Cerrado, Pantanal e Mata Atlântica. Habita beira de rios e lagoas. Na Represa Guarapiranga esteve presente nos pontos RB5 e EM14. Pode ser identificada pela presença de glândulas opacas esbranquiçadas na face abaxial das lâminas e se diferencia de $P$. punctatum pela ausência de glândulas punctiformes castanhas no perigônio.

Material examinado: Represa Guarapiranga, GUA5, 10.X.2007, M.E.F.Rodrigues 238 (ESA). Represa Guarapiranga, Marina Silvester, 10.X.2007, M.E.F.Rodrigues 281 (ESA). Represa Guarapiranga, 4G, 19.I.2007, M.E.F.Rodrigues 84 (ESA). Represa Guarapiranga, EM14, 16.X.2008, M.E.F.Rodrigues 000436b (ESA). Represa Guarapiranga, EM14, 6.XI.2008, M.E.F.Rodrigues 543 (ESA, HUEFS). Represa Guarapiranga, GUA5, 09.XI.2007, M.E.F.Rodrigues 303 (ESA, HUEFS). Represa Guarapiranga, EM14, 6.VIII.2008, M.E.F.Rodrigues 392 (ESA). Represa Guarapiranga, GUA5, 19.IX.2007, M.E.F.Rodrigues 216 (ESA).

118. Polygonum paraguayense Wedd., Ann. Sci. Nat., Bot., sér. 3. 13: 253. 1849.

Fig.: $5 j$

Erva emergente, decumbente, 1-2m alt., ramos pubescentes, tricomas simples e capitados. Folhas pubescentes, ócrea até $2 \mathrm{~cm}$ compr., ápice com longos cílios; pecíolo $0,5-1 \mathrm{~cm}$ compr.; lâmina ovallanceolada, $2-14 \times 1-5 \mathrm{~cm}$, ápice e base atenuados, tricomas capitados. Inflorescência em pleiotirsos terminais, não compactas, até $7 \mathrm{~cm}$ compr., esverdeadas, pedúnculos de $1-4 \mathrm{~cm}$ compr., tricomas glandulares. Flores com ocreólas com tricomas tectores e capitados, perigônio 5-lobado, branco ou esverdeado. Núcula geralmente lenticular com algumas trígonas no mesmo espécime, até $4 \mathrm{~mm}$ de compr. Distribuição na Argentina, Paraguai e Brasil. No Brasil ocorre em Mato Grosso do Sul e São Paulo atingindo o Pantanal e o Cerrado. Encontrada em beira de rios, lagoas e locais inundáveis. Na Represa Guarapiranga esteve presente nos pontos RB5 e EG19. Pode ser distinta pelos tricomas capitados em toda a planta. Segundo Melo \& Marcondes-Ferreira (2009) esta espécie é rara em São Paulo, não tendo sido coletada a mais de 45 anos e consta com a núcula trígona, porém segundo Melo (com. pess.) será feita uma revisão para corrigir a chave.

Material examinado: Represa Guarapiranga, EG19, 6.VIII.2008, M.E.F.Rodrigues 391 (ESA, HUEFS). Represa Guarapiranga, RB5, 7.IV.2009, M.E.F.Rodrigues 556 (ESA, HUEFS).

119. Polygonum punctatum Elliott, Sketch Bot. S. Carolina 1(5): 455-456. 1821[1817].

Erva-de-bicho.

Erva emergente, ereta, até $1 \mathrm{~m}$ alt. Folhas com ócreas cilíndricas, glabras a pilosas, longos tricomas no ápice; pecíolo de até $1 \mathrm{~cm}$ compr., lâmina lanceolada ou oval-lanceolada, $5-15 \times 0,6-3 \mathrm{~cm}$, glabras, 
verde com manchas púrpuras, glândulas puntiformes em ambas as faces. Inflorescência em pleiotirsos, terminais, longo-pedunculadas, laxiflora, até $11 \mathrm{~cm}$ compr. Flores com ocreólas glabras e ciliadas no ápice, perigônio 5-lobado, branco ou esverdeado, muitas glândulas punctiformes castanhas. Núcula trígona-ovalada envolvida pelo perigônio, glândulas punctiformes castanhas. Distribuição na América tropical e subtropical. Ampla ocorrência no Brasil atingindo todos os biomas brasileiros. Considerada ruderal em margens de rios e lagoas de margens poluídas. Na Represa Guarapiranga esteve presente nos pontos PA2, IT10, EM13 ao EG16 e EG20. Identificada pela presença de glândulas punctiformes em toda planta, mais evidentes e castanhas no perigônio.

Material examinado: Represa Guarapiranga, GUA6, 10.X.2007, M.E.F.Rodrigues 262 (ESA). Represa Guarapiranga, GUA5, 3.V.2007, M.E.F.Rodrigues 128 (ESA, HUEFS). Represa Guarapiranga, GUA5, 3.V.2007, M.E.F.Rodrigues 129 (ESA, HUEFS). Represa Guarapiranga, 7G, 30.I.2007, M.E.F.Rodrigues 96 (ESA). Represa Guarapiranga, EM14, 16.X.2008, M.E.F.Rodrigues 000436a (ESA). Represa Guarapiranga, EM13, 2.IX.2008, M.E.F.Rodrigues 405 (ESA). Represa Guarapiranga, EM14, 2.IX.2008, M.E.F.Rodrigues 401 (ESA). Represa Guarapiranga, EG17, 2.IX.2008, M.E.F.Rodrigues 407 (ESA, HUEFS). Represa Guarapiranga, EG17 , 6.VIII.2008, M.E.F.Rodrigues 390 (ESA). Represa Guarapiranga, GUA4, 10.X.2007, M.E.F.Rodrigues 272 (ESA). Represa Guarapiranga, GUA6, 19.IX.2007, M.E.F.Rodrigues 224 (ESA). Represa Guarapiranga, GUA5, 5.VII.2007, M.E.F.Rodrigues 204 (ESA). Represa Guarapiranga, GUA5, 19.IX.2007, M.E.F.Rodrigues 215 (ESA). Represa Guarapiranga, EM13, 6.VIII.2008, M.E.F.Rodrigues 398 (ESA, HUEFS). Represa Guarapiranga, GUA6, 5.VII.2007, M.E.F.Rodrigues 203 (ESA).

120. Rumex obtusifolius L., Sp. PI. 1: 335-336. 1753.

Língua-de-vaca.

Erva emergente, ereta, até $1,2 \mathrm{~m}$ alt., caule sem ramificações. Folhas basais em roseta e caulinares alternas com ócreas glabras, hialinas de ápice truncado, pecíolo de 1,5-15cm compr., lâminas elíptico-lanceoladas, 5-30x2-12cm, as maiores localizadas na base e menores no ápice, margem inteira ou ondulada, glabra. Inflorescências em tirsos paniculados, eretas, axilares, concentradas na parte superior dos ramos, densifloros, flores brancas ou amarelo-esverdeadas, distribuídas em verticilos afastados, frequentemente com pequenas folhas na base dos verticilos. Núcula com calos dorsais desenvolvidos, amarelados e menores que o perigônio persistente em forma de alas triangulares, margens fimbriadas ou denteadas, verdes. Distribuição cosmopolita. Ocorre da Bahia ao Sul do Brasil, atingindo Cerrado, Mata Atlântica e Pampa. Considerada ruderal, preferencialmente em terrenos alagadiços, sobre solos ácidos. $\mathrm{Na}$ Represa Guarapiranga esteve presente nos pontos PA2, RB5,
IT9, IT10, EM13 e EG17. Pode ser identificada através do perigônio frutífero com margem denteada ou fimbriada.

Material examinado: Represa Guarapiranga, GUA1, 14.XII.2007, M.E.F.Rodrigues 317 (ESA, HUEFS). Represa Guarapiranga, EM13, 7.XI.2008, M.E.F.Rodrigues 445 (ESA, HUEFS). Represa Guarapiranga, 9G, 30.I.2007, M.E.F.Rodrigues 201 (ESA). Represa Guarapiranga, IT9, 5.VIII.2008, M.E.F.Rodrigues 435 (ESA).

\section{PONTEDERIACEAE}

Bibliografia: Kissmann \& Groth (2000), Pott \& Pott (2000), Faria \& Amaral (2005), Amaral et al. (2008).

\section{Chave para as espécies}

1. Plantas não enraizadas, base do pecíolo esférico .................................. 121. Eichhornia crassipes

1'. Plantas enraizadas, base do pecíolo alongado

2. Lâmina foliar reniforme, de 1-3,5 x 2-4cm, pedúnculo floral glabro ......................122. Heteranthera reniformis

2'. Lâmina foliar oval-lanceolada a cordada de $22 \mathrm{x}$

$3,5 \mathrm{~cm}$, pedúnculo floral piloso ... 123. Pontederia cordata

121. Eichhornia crassipes (Mart.) Solms, Monogr. Phan. 4: 527. 1883.

Aguapé, aguapé-de-flor-roxa.

Erva flutuante livre ou enraizada em água rasas, ereta, $10-25(100) \mathrm{cm}$ alt., carnosa e suculenta, tecido aerenquimatoso, estolonífera, raízes abundantes, azuladas quando novas. Folhas, aéreas em roseta, pecíolo $10-15 \mathrm{~cm}$ compr., inflado quando flutuante e delgado se enraizada, lâmina, reniforme, arredondada, lisa, glabra, brilhante. Inflorescência em espiga, multiflora, escapo de $15 \mathrm{~cm}$ compr., guarnecido por brácteas. Flores vistosas, zigomorfas, 6 tépalas esverdeadas no tubo e lilases a azuladas nos lobos, tépala superior com nervuras violáceas e mancha amarela no centro, margem inteira, 6 estames de anteras sagitadas, violáceas, filetes podem ser curtos, médios ou longos em cada indivíduo. Cápsula com muitas sementes. Nativa do Brasil mas introduzida em muitas áreas tropicais e temperadas do mundo. Ocorre amplamente em todas as regiões do Brasil atingindo todos os biomas brasileiros. Facilmente encontrada em lagos, lagoas, rios e riachos. $\mathrm{Na}$ Represa Guarapiranga esteve presente nos pontos PA2 ao PA4, IT9, EM12, EM14, EG16, EG17 e EG20, geralmente vegetativa, jovem, isoladas ou com baixa densidade, não apresentando riscos de infestação. Pode ser identificada pelas flores vistosas, lilases e pecíolos inflados.

Material examinado: Represa Billings, C, 13.IV.2005, M.E.F.Rodrigues 12 (ESA). Represa Billings, L, 
Levantamento de plantas aquáticas e palustres na represa Guarapiranga, São Paulo

20.IV.2005, M.E.F.Rodrigues 35 (ESA). Represa Guarapiranga, PA2, 16.X.2008, M.E.F.Rodrigues 565 (ESA).

122. Heteranthera reniformis Ruiz \& Pav., Fl. Peruv. 1: 43, pl. 71, f. a. 1798.

Hortelã-do-brejo, pavia, aguapé-mirim.

Erva emergente, ereta, até $15 \mathrm{~cm}$ alt. estolonífera, subcarnosa. Folhas alternas, bainha membranácea, pecíolo $6-12 \mathrm{~cm}$ compr., lâminas reniformes ou cordiformes, $2-4 \mathrm{~cm}$ larg. Inflorescência em espigas, terminais, 2-8 flores, espata cilíndrica. Flores com 6 tépalas desiguais, brancas a lilases, mancha amarelo-ouro e margem arroxeada na tépala superior, piloso-glandular na face dorsal, 3 estames, sendo 2 anteras amarelas e 1 antera maior e azulada. Fruto não observado. Distribuição em regiões tropicais e subtropicais da América e África. Ampla ocorrência em todas as regiões do Brasil, atingindo todos os biomas brasileiros. Encontrada geralmente em alagados. Na represa Guarapiranga esteve presente no ponto EM14. Pode ser identificada através das flores de pétalas delicadas, alvas com guia de néctar.

Material examinado: Represa Guarapiranga, EM14, 3.XII.2008, M.E.F.Rodrigues 488 (ESA).

123. Pontederia cordata L., Sp. PI. 1: 288. 1753. Mururê, mureru, rainha-dos-lagos, aguapé.

Erva anfíbia, ereta, até $60 \mathrm{~cm}$ alt., estolonífera. Folhas basais, longo-pecioladas, folha solitária no escapo floral curto-peciolada, lâminas ovallanceoladas, base e ápice arredondados, $22 \times 3,5 \mathrm{~cm}$, carnosas, lisas, glabras e brilhantes. Inflorescência em espiga, densiflora, vistosa, terminal, pedúnculo hirsuto, bráctea oboval na base. Flores de 10-12mm compr., azulada com mancha amarela no centro da tépala superior, hirsutas, 6 estames, anteras azuis. Fruto não observado. Distribuição em regiões quentes e temperadas da América do Sul. Ocorre amplamente em todas as regiões do Brasil atingindo todos os biomas brasileiros. Habita alagados e margens de lagos, lagoas, rios e riachos. $\mathrm{Na}$ Represa Guarapiranga esteve presente no ponto EM12. Pode ser identificada pela inflorescência vistosa, multiflora, congesta, lilás a azulada, densa pilosidade.

Material examinado: Represa Guarapiranga, EM12, 3.XII.2008, M.E.F.Rodrigues 478 (ESA).

\section{PRIMULACEAE}

Bibliografia: Freitas \& Carrijo (2016), Garcia \& Izumizawa (2003), Amaral et al. (2008).
124. Lysimachia minima (L.) U.Manns \& Anderb., Willdenowia 39: 49-54. 2009.

Centunculus minimus L., Sp. PI. 1: 116. 1753.

Anagallis minima (L.) E.H.L. Krause., Deutschl. FI. (Sturm) 9: 251. 1901.

Erva anfíbia, ereta ou prostrada, $5 \mathrm{~cm}$ compr., inconspícua. Folhas alternas, subsésseis, pecíolo 0,5mm compr., lâmina oblonga, $5 \times 1 \mathrm{~mm}$, ápice mucronado, margem inteira, nervura broquidódroma. Flores solitárias, axilares, 5-meras, pecíolo 1-3mm compr., cálice de lacínios lanceolados, membranáceos, verde-claros, corola branca, persistente, aderente ao fruto. Pixídio globoso, muitas sementes cônicas de superfície brilhante. Ampla distribuição, Ásia, Europa meridional, África tropical e Américas. No Brasil ocorre dispersadamente do Nordeste ao Sul, atingindo Caatinga, Cerrado e Mata Atlântica. Considerada tanto planta de restinga quanto vegetação aquática. Na Represa Guarapiranga esteve presente apenas no ponto EG15. E uma planta delicada que pode ser identificada através do porte e dos pixídios axilares.

Material examinado: Represa Guarapiranga, EG15, 7.I.2009, M.E.F.Rodrigues 563 (ESA).

\section{RUBIACEAE} (2008).

Bibliografia: Jung-Mendaçolli (2007), Amaral et al.

\section{Chave para as espécies}

1. Lâminas orbiculares, base arredondada, hirsutas ........................126. Coccocypselum capitatum

1'. Lâminas elípticas, linear-lanceoladas, obovais ou oblanceoladas, base não arredonda, glabras ou escabras

2. Folhas verticiladas 125. Borreria capitata

2'. Folhas opostas

3. Ramos com menos de $1 \mathrm{~mm}$ de diâm., lâmina foliar de até $9 \mathrm{~mm}$ de compr., estípula interpeciolar de 0,1$0,2 \mathrm{~mm}$ compr. .................128. Oldenlandia salzmanii

3'. Ramos com mais de $3 \mathrm{~mm}$ de diâm., lâmina foliar com mais de $20 \mathrm{~mm}$ de compr., estípula interpeciolar de $4-8 \mathrm{~mm}$ compr. 127. Diodia saponariifolia

125. Borreria capitata (Ruiz \& Pav.) DC., FI. Peruv. 1: 61, t. 91, f.b. 1798.

Arbusto ou subarbusto anfíbio, ereto, até $1 \mathrm{~m}$ alt., caule ramificado, ramos hirsutos no ápice. Folhas verticiladas, sésseis, estípula interpeciolar fimbriada, lâmina elíptica, 1-2,5×0,3-0,7cm, glabra, nervuras 
proeminentes na face abaxial. Inflorescência glomérulo globoso terminal e 2-3 subglobosos axilares no ápice dos ramos, multifloro. Flores gamopétalas, 4meras, pétalas brancas, tricomas na face interna do tubo, estames excertos roxos. Fruto com 2 mericarpos deiscentes e persistentes, separados no ápice, sementes com sulcos transversais. Amplamente distribuída na América do Sul. No Brasil ocorre em todas as regiões atingindo a Amazônia, Caatinga, Cerrado e Mata Atlântica. Localiza-se em solos arenosos, entre rochas e pode ser encontrada em solos pobres, contudo não é muito agressiva. Na Represa Guarapiranga esteve presente nos pontos PA4, RB5, EM12 e EG15. Pode ser identificada pela inflorescência.

Material examinado: Represa Guarapiranga, EM12, 8.VII.2008, M.E.F.Rodrigues 378 (ESA). Represa Guarapiranga, GUA6, 10.X.2007, M.E.F.Rodrigues 254 (ESA). Represa Guarapiranga, EG15, 8.VII.2008, M.E.F.Rodrigues 384 (ESA). Represa Guarapiranga, GUA5, 19.IX.2007, M.E.F.Rodrigues 214 (ESA).

126. Coccocypselum capitatum (Graham) C.B. Costa \& Mamede, Brittonia 58(2): 175. 2006

Fig.: 51

Erva anfíbia, prostrada, muito ramificada, hirsuta. Folhas opostas, estípulas interpeciolares, pecíolo até $6 \mathrm{~mm}$ compr., hirsuto, lâminas orbiculares, ovadas, base arredondada, truncada ou cordada, ápice apiculado, hirsutas em ambas as faces. Inflorescência axilar, semiglobosa, pedúnculo $1-3 \mathrm{~cm}$ compr., hirsuto. Flores 4-meras, cálice hirsuto em ambas as faces, corola com tubo amarelado fauce e lobos lilases a roxos. Frutos unidos pela base, baga quando jovem e seco quando maduro. Planta endêmica do Brasil encontrando-se desde a Bahia estendendo para Espírito Santo até o Rio Grande do Sul, atingindo a Mata Atlântica. Comum nas bordas de matas e solos arenosos das restingas. Na Represa Guarapiranga esteve presente nos pontos PA2, IT11, EM12 e EG17. Pode ser identificada pelo indumento hirsuto em toda planta e infrutescência globosa com os frutos unidos pela base.

Material examinado: Represa Guarapiranga, IT11, 3.XII.2008, M.E.F.Rodrigues 466 (ESA). Represa Guarapiranga, EG17, 4.XII.2008, M.E.F.Rodrigues 496 (ESA).

127. Diodia saponariifolia (Cham. \& Schltdl.) K. Schum. in Mart., FI. bras. 6(6): 16. 1889.

Erva anfíbia, decumbente a ascendente, até $50 \mathrm{~cm}$ alt., ramos glabros, fistulosos. Folha oposta, estípula interpeciolar com 3 lobos, 4-8mm compr., pecíolo 1-2mm compr., lâmina obovada a oblanceolada, 2,3-6×1-1,8cm, escabriúscula, margem ondulada. Flores solitárias, axilares, sésseis, cálice 2lobado, corola 4-lobada, gamopétala, pilosa na face interna, branca, estames excertos brancos. Fruto com mericarpos indeiscentes, incluso na bainha estipular, sementes sulcadas na face ventral. No Brasil ocorre na Bahia, todo Centro-Oeste, Sudeste e Sul atingindo a Caatinga, Cerrado, Pantanal, Mata Atlântica e Pampa. Comum em terrenos costeiros, úmidos, arenosos. Pode ser identificada pela bainha estipular com 3 lobos. Na Represa Guarapiranga esteve presente somente no ponto EM14.

Material examinado: Represa Guarapiranga, EM14, 6.XI.2008, M.E.F.Rodrigues 462 (ESA). Represa Guarapiranga, EM14, 3.XII.2008, M.E.F.Rodrigues 473 (ESA).

128. Oldenlandia salzmannii (DC.) Benth. \& Hook. f. ex B.D. Jacks., Index Kew. 2: 58. 1873.

Erva anfíbia, prostrada, até $25 \mathrm{~cm}$ compr., ramos menores que $1 \mathrm{~mm}$ de diâm, glabros. Folhas opostas, sésseis a subsésseis, estípula interpeciolar, 0,1-0,2mm compr., lâmina oval a linear-lanceolada, 3$9 \times 1-3 m m$, glabra. Flores 1-2, terminais ou axilares, longistilas e brevistilas, pedicelo 2-7mm compr., corola gamopétala, rósea, tricomas na fauce, estames adnatos no tubo, anteras azuis. Cápsula semiglobosa. Distribuição no sul dos Estados Unidos e América do Sul. No Brasil ocorre nos estados de Ceará, Bahia, Distrito Federal, Mato Grosso, Mato Grosso do Sul, toda a região do Sudeste e Sul atingindo a Caatinga, Cerrado e Mata Atlântica. Encontrada em locais úmidos, alagados. Na Represa Guarapiranga esteve presente nos pontos PA2, EM12, EM14 ao EG17 e EG19, sendo que no ponto EG16 foi coletada como submersa livre, com folhas linear-lanceoladas e vegetativas. Após cultivo em laboratório foi possível verificar a variação do formato e tamanho das folhas após a água secar e a planta se enraizar. Pode ser identificada pela corola gamopétala, rósea e estames de anteras azuis.

Material examinado: Represa Billings, ponto 6 (transecto), 30.V.2007, M.E.F.Rodrigues 191 (ESA). Represa Guarapiranga, EG16, 15.X.2008, M.E.F.Rodrigues 418 (ESA). Represa Guarapiranga, PA2 e EM14, 3.IX.2008, M.E.F.Rodrigues 416 (ESA). Represa Guarapiranga, GUA4, 10.X.2007, M.E.F.Rodrigues 275 (ESA). Represa Guarapiranga, GUA4, 9.XI.2007, M.E.F.Rodrigues 297 (ESA). Represa Guarapiranga, EG16, 6.VIII.2008, M.E.F.Rodrigues 388 (ESA).

\section{SOLANACEAE}

Bibliografia: Amaral et al. (2008).

\section{Chave para as espécies}

1. Folhas basais em roseta, sésseis, pinatipartidas, 3-7 $\times 0,5-3 \mathrm{~cm}$...............................129. Nicotiana longiflora

1'. Folhas alternas, pecioladas, simples, 9-28x4,5-

$12 \mathrm{~cm}$ 
Levantamento de plantas aquáticas e palustres na represa Guarapiranga, São Paulo

129. Nicotiana longiflora Cav., Descr. PI. 106. 1802.

Erva emergente, ereta, até $1 \mathrm{~m}$ alt., ramos piloso-glandulares. Folhas basais em roseta, sésseis, lâminas lanceoladas, pinatipartidas, base amplexicaule, $15-23 \times 4-5,5 \mathrm{~cm}$, margem ondulada, coriáceas, folhas apicais alternas, sésseis, lâminas lanceoladas, ápice atenuado, base decorrente, 3$7 \times 0,5-3 \mathrm{~cm}$, margem inteira, coriáceas, pilosoglandulares. Inflorescência racemosa, terminal, pauciflora. Flores 5-meras, cálice campanulado verde, corola hipocrateriforme, profundamente lobada, branco-rosada, estames inseridos na metade superior do tubo, de tamanhos sutilmente diferentes, não geniculados, anteras púrpuras. Cápsula oval com sépalas persistentes. Distribuição no sul da Bolívia, Paraguai, norte da Argentina, Uruguai e Chile. No Brasil possui ocorrência do Rio de Janeiro ao Sul atingindo apenas Mata Atlântica e Pampa. Encontrada em áreas antrópicas. $\mathrm{Na}$ Represa Guarapiranga foi encontrada um banco grande no ponto IT10. Pode ser identificada pelas folhas basais robustas, e corola com tubo de até $5 \mathrm{~cm}$ de compr., profundamente lobada.

Material examinado: Represa Guarapiranga, GUA1, 14.XII.2007, M.E.F.Rodrigues 313 (ESA).

\section{Nicotiana sp.}

Fig.: $5 \mathrm{~m}$

Erva emergente, robusta, ereta, até $1 \mathrm{~m}$ alt., caule pubescente. Folhas simples, alternas, pecíolo alado, lâminas elípticas, ápice agudo, base decorrente, 9-28x4,5-12cm, glabras, margem inteira. Inflorescência terminal. Flores 5-meras, gamopétalas. Só havia botões florais, por isso não foi possível identificar a espécie. Esteve presente no ponto IT10 associada à Nicotiana longiflora. Pode ser identificada pelas folhas robustas, base decorrente.

Material examinado: Represa Guarapiranga, GUA1, 14.XII.2007, M.E.F.Rodrigues 314 (ESA).

\section{TYPHACEAE}

Bibliografia: Kissmann \& Groth (2000), Pott \& Pott (2000), Amaral et al. (2008).

131. Typha latifolia L., Sp. PI. 2: 971. 1753. Taboa.

Erva emergente, ereta, até $2,5 \mathrm{~m}$ alt., cespitosa. Folhas alternas dísticas, eretas, bainhas escariosas, amarelo-palha, aurículas membranáceas no ápice, lâminas linear-lanceoladas, 100-200x0,8-
$2 \mathrm{~cm}$, coriáceas, presença de aerênquima, glabra, margem inteira. Inflorescência em espiga terminal, densiflora, multiflora, cilíndrica, castanha escura, pedúnculo de até $2 \mathrm{~m}$ compr., glabro, rígido, cilíndrico, raque secundária filiforme. Flores unissexuais, estaminadas localizadas na parte superior da espiga, 2-3 estames, brácteas filiformes e apêndice do conectivo arredondado, flores pistiladas na parte inferior sem bractéolas, estigmas lanceolados. Aquênios fusiformes. Ampla distribuição no Continente Americano. No Brasil ocorre nos estados Pará, Minas Gerais, São Paulo, Paraná e Rio Grande do Sul atingindo Amazônia e Mata Atlântica. Encontrada em várzeas úmidas, lagos, canais e margens de rios. $\mathrm{Na}$ Represa Guarapiranga esteve presente nos pontos IT10, IT11, EM12, EG15, EG17, EG19 sempre em grandes bancos nas margens palustres da represa. Pode ser identificada através da inflorescência em espiga terminal castanha escura.

Material examinado: Represa Guarapiranga, IT11, 3.IX.2008, M.E.F.Rodrigues 412 (ESA).

\section{URTICACEAE}

Bibliografia: Amaral et al. (2008).

132. Boehmeria cylindrica (L.) Sw., Prodr. 34. 1788.

Urtiga.

Erva a subarbusto anfíbio, ereto, até $80 \mathrm{~cm}$ alt., ramos pilosos. Folhas opostas, pecíolo $1-3,5 \mathrm{~cm}$ compr., estípulas inconspícuas, lâminas, ovallanceoladas, ápice acuminado, 4,5-13,5x2,5-7,5cm, glabras ou velutinas, margem fortemente serreada. Inflorescência e flores não vistas. Infrutescência em espigas axilares, $1-3,5 \mathrm{~cm}$ compr., aglomerados de frutos espaçados ao longo do pedúnculo ou somente nas axilas foliares. Aquênios ovais de ápice acuminado, envolvidos pelas tépalas, castanhoesverdeados a castanho-amarelados. Ocorre em Rondônia e toda a região do Nordeste, Centro-Oeste, Sudeste e Sul do Brasil atingindo Caatinga, Pantanal, Cerrado, Mata Atlântica. Na Represa Guarapiranga esteve presente nos pontos PA2, CC7 e IT10. Pode ser identificada pelas folhas fortemente serreadas, verde-brilhantes e infrutescência em espigas axilares com frutos castanho-amarelados.

Material examinado: Represa Guarapiranga, GUA4, 9.XI.2007, M.E.F.Rodrigues 310 (ESA). Represa Guarapiranga, GUA2, 3.V.2007, M.E.F.Rodrigues 122 (ESA). Represa Guarapiranga, , 19.I.2007, M.E.F.Rodrigues 90 (ESA). Represa Guarapiranga, GUA1, 3.V.2007, M.E.F.Rodrigues 118 (ESA). Represa Guarapiranga, GUA2, 14.VI.2007, M.E.F.Rodrigues 198 (ESA). 


\section{XYRIDACEAE} (2008).

Bibliografia: Wanderley (2002), Amaral et al.

133. Xyris macrocephala Vahl, Enum. PI. [Kunth], 2: 204, 1805.

Xyris laxifolia Mart., Flora 24(Beibl. 2): 53. 1841.

Navalha-de-barbear.

Erva emergente, ereta, até $1 \mathrm{~m}$ alt., cespitosa. Folhas basais, alternas dísticas, 13-42(65)cm compr., bainha púrpuro-avermelhada a castanho-arroxeada na base, margem hialina, 9-20(27)cm compr., lâmina linear-lanceolada, menor que pedúnculo, estrias avermelhadas, glabra, margem inteira. Inflorescência em espiga terminal, ovoide a elipsóide, 1-2x0,8-1cm, escapo $60-85 \mathrm{~cm}$ compr., glabro, brácteas dispostas em espiral, margens castanhas e 3 pétalas amarelas, 3 estaminódios pilosos amarelos, 3 estames, anteras sagitiforme, placentação parietal. Cápsula com numerosas sementes reticuladas de ápice acuminado. Amplamente distribuída em toda América tropical até a Argentina. Ocorre em todo o território brasileiro atingindo todos os biomas brasileiros. Encontrada em ambiente alagados com solo ácido ou arenoso, campos rupestres, campos gerais, bordas de matas e ambientes perturbados. Na Represa Guarapiranga esteve presente nos pontos PA2 e EM12, considerados alagados. Pode ser identificada pela espiga oval a elipsóide, brácteas coriáceas, verdeacizentadas, flores amarelas e folhas geralmente com estrias avermelhadas.

Material examinado: Represa Guarapiranga, GUA4, 14.XII.2007, M.E.F.Rodrigues 322 (ESA). Represa Guarapiranga, PA2, 4.XII.2008, M.E.F.Rodrigues 514 (ESA). Represa Guarapiranga, EM12, 3.XII.2008, M.E.F.Rodrigues 476 (ESA). Represa Guarapiranga, PA2, 7.VII.2008, M.E.F.Rodrigues 357 (ESA).

\section{ZINGIBERACEAE}

Bibliografia: Kissmann \& Groth (2000), Amaral et al. (2008)

134. Hedychium coronarium J. König, Observ. Bot. 3: 73-74. 1783.

Lírio-do-brejo

Erva emergente, ereta, 1-2m alt., caule muito enfolhado. Folhas alternas dísticas, bainhas longas cobrindo os entrenós do caule, lígulas membranáceas de $2-3 \mathrm{~cm}$ compr., lâminas linear-lanceoladas, 30$60 \times 10-15 \mathrm{~cm}$, glabras, nervação pinado-paralela, nervura principal proeminente na face dorsal. Inflorescência terminal, brácteas parcialmente sobrepostas, espiraladas. Flores 2-3 por bráctea, cálice membranáceo, incluso nas brácteas, corola branca, pétalas lineares inconspícuas, estaminódios petalóides, brancos, vistosos, 2 elíptico-lanceolados livres e 2 soldados, 1 estame fértil, estilete longo. Baga deiscencente, elíptica, sementes vermelhas. Originária do Himalaia e Madagascar e introduzida em todo mundo, ampla distribuição no Continente Americano. Ocorre em quase todo o território brasileiro atingindo Amazônia, Caatinga, Cerrado, Pantanal e Mata Atlântica. Pode invadir canais, riachos e outras coleções de água pouco profunda, mas o habitat ideal é o de baixadas úmidas em regiões de temperatura elevada durante todo 0 ano. $\mathrm{Na}$ Represa Guarapiranga esteve presente nas margens dos pontos IT10 e IT11. Facilmente identificada pelo porte robusto, folhas alternas dísticas e inflorescência terminal, brácteas parcialmente sobrepostas espiraladas.

Material examinado: Material não coletado, somente observado.

\section{Agradecimentos}

A Capes pelos 24 meses de bolsa de mestrado. Á FAPESP - Projeto "Programa de Monitoramento e Manejo de Macrófitas Aquáticas nos reservatórios do Estado de São Paulo: Subsídio a Políticas Públicas" - 2006/51705. Ao CNPq pelo financiamento do Banco de Dados de Macrófitas e CdRom (proc. 471184/2006-3 e 552540/2006-4). Ao fundo de Cultura e Extensão da USP pelo recurso disponibilizado para confecção do cartaz e exposição fotográfica.

Aos especialistas pela confirmação das identificações taxonômicas das respectivas famílias ou gêneros: Prof ${ }^{\mathrm{a}} \mathrm{Dr}^{\mathrm{a}}$. Ana Odete Santos Vieira (Onagraceae); Dra . Aparecida Donisete de

Faria (Eleocharis); Prof. Dr. Claudio Augusto Mondin (Enydra); Prof. Dr. Christian Linck (Juncaceae); Prof ${ }^{a}$ $\mathrm{Dr}^{\mathrm{a}}$ Efigenia Melo (Polygonaceae); Prof. Dr. João A. N. Batista (Habenaria); Prof. Dr. João Renato Stehmann (Solanaceae); Prof. Dr. Jefferson Prado (Salviniaceae); Prof. Dr. José Iranildo Miranda de Melo (Euploca); Prof ${ }^{-} \mathrm{Dr}^{\mathrm{a}}$ Sonia Marisa Hefler (Cyperus e Pycreus); Prof. Dr. Tarcisio S. Filgueiras (Poaceae).

A toda equipe do laboratório de limnologia da USP, especialmente a Célia C. L. Macedo e o Rafael Taminato pela colaboração em campo e com as fotos.

\section{Referências}

AMARAL, M.C.E., BRITTICH, V., FARIA, A.D., ANDERSON, L.O. \& AONA, L.Y. 2008. Guia de campo para plantas aquáticas e palustres do Estado de São Paulo. Holos Editora. Ribeirão Preto. 
Levantamento de plantas aquáticas e palustres na represa Guarapiranga, São Paulo

AMARAL, M.C.E. 2015. Menyanthaceae. In Lista de Espécies da Flora do Brasil. Jardim Botânico do Rio de Janeiro. Disponível em: <http://floradobrasil.jbrj.gov.br/jabot/floradobrasil/ FB10054>.

ANDERSON, L.O. \& AMARAL, M.C.E. 2005. Menyanthaceae. In M.G.L. Wanderley, G.J. Shepherd, T.S. Melhem, S.E. Martins, M. Kirizawa \& A.M. Giulietti (eds). Flora fanerogâmica do Estado de São Paulo. Fapesp, RiMa. São Paulo, vol. 4, p. 277-278.

AONA, L.Y.S. \& AMARAL, M.C.E. 2002. Hydrocharitaceae. In M.G.L. Wanderley, G.J. Shepherd \& A.M. Giulietti (eds.). Flora fanerogâmica do Estado de São Paulo. HUCITEC, FAPESP. São Paulo, vol. 2, p.123-127.

ARAUJO, A.C. \& LONGHI-WAGNER, H.M. 1996. Levantamento taxonômico de Cyperus L. subg. Anosporum no Rio Grande do Sul. Acta bot. brasil.10(1): 153-192.

BALSLEV, H. 1996. Juncaceae. Flora Neotropica Monographs 68: 1-167.

BARRETO, R.C. 2005. Commelinaceae. In M.G.L. Wanderley, G.J. Shepherd, T.S. Melhem, S.E. Martins, M. Kirizawa \& A.M. Giulietti (eds.). Flora fanerogâmica do Estado de São Paulo. RiMa, FAPESP. São Paulo, vol.4, p.194-210.

BARROS, F.D., VINHOS, F., RODRIGUES, V.T., BARBERENA, F.F.V.A. \& FRAGA, C.N. 2015. Orchidaceae. In Lista de Espécies da Flora do Brasil. Jardim Botânico do Rio de Janeiro. Disponível em: < (http://floradobrasil.jbrj.gov.br/ 2015/FB011696) >.

BARROSO, G.M. 1952. Scrophulariaceae indígenas e exóticas do Brasil. Rodriguésia 15(27): 944.

BARROSO, G.M., PEIXOTO, A.L., ICHASO, C.L.F., GUIMARÃES, E.F. \& COSTA, C.G. 2008. Sistemática de angiospermas do Brasil. UFV. Viçosa, vol. 1.

BARROSO, G.M., PEIXOTO, A.L., ICHASO, C.L.F., GUIMARÃES, E.F., COSTA, C.G. \& LIMA, H.C. 1991. Sistemática de angiospermas do Brasil. UFV. Viçosa, vol. 2 e 3.

BATISTA, J.A.N., BIANCHETTI, L.D.B., MIRANDA, Z. D.J.G. 2006. A revision of Habenaria section Macroceratitae (Orchidaceae) in Brazil. Brittonia 58(33): 10-41.
BEYRUTH, Z. 1996. Comunidade fitoplanctônica da represa de Guarapiranga: 1991-92. Aspectos ecológicos sanitários e subsídios para reabilitação da qualidade ambiental. Tese de Doutorado. Faculdade de Saúde Pública, USP, São Paulo.

BINI, L.M., OLIVEIRA, L.G., SOUZA, D.C., CARVALHO, P. \& PINTO, M.P. 2005. Patterns of the aquatic macrophyte cover in Cachoeira Dourada Reservoir (GO-MG). Braz. J. Biol. 65:1924. Disponível em: < http://www.scielo.br/ scielo.php?script=sci_arttext $\&$ pid $=$ S1519$6984200500014 \& \mathrm{nrm}=$ iso $>$.

BITTRICH, V. 2003. Clusiaceae. In M.G.L. Wanderley, G.J. Shepherd, T.S. Melhem, A.M. Giulietti \& M. Kirizawa (eds.). Flora fanerogâmica do Estado de São Paulo. RiMa, FAPESP. São Paulo, vol. 3, p.45-62.

BOVE, C.P., GIL, A.S.P., MOREIRA, C.B. \& ANJOS, R. F.B. 2003. Hidrófitas fanerogâmicas de ecossistemas aquáticos temporários da Planície Costeira do Estado do Rio de Janeiro, Brasil. Acta bot. bras. 17(1): 119-153.

BOVE, C.P. \& PAZ, J. 2009. Guia de campo das plantas aquáticas do Parque Nacional da Restinga de Jurubatiba, Rio de Janeiro, Brasil. Museu Nacional, UFRJ. Rio de Janeiro.

BRANDÃO, M., LACA-BUENDIA, J.P. \& GAVILANES, M.L. 1989. Plantas palustres e aquáticas que se comportam como invasoras, no estado de Minas Gerais. Acta bot. bras. 2(1): 255-265.

BREMER, B., BREMER, K., CHASE, M.W., FAY, M.F., REVEAL, J.L. \& SOLTIS, D.E. 2009. An update of the Angiosperm Phylogeny Group classification for the orders and families of flowering plants: APG III. Bot. J. Linn. Soc.161(2):105-121.

BRIDSON, G.D.R. \& SMITH, E.R. 1991. BotanicoPeriodicum-Huntianun _ $\quad$ Supplementum. Pittsburgh: Carnegie Mellon University.

BRUMMIT, R.K. \& POWELL, C.E. 1992. Authors of plant names. Royal Botanic Gardens. Kew.

CAMARGO, A.F.M., PEZZATO, M.M. \& HENRYSILVA, G.G. 2003. Fatores limitantes à produção primária de macrófitas aquáticas. In S.M. Thomaz \& L.M. Bini (eds.) Ecologia e manejo de macrófitas aquáticas. EDUEM. Maringá, p. 59-83.

CARVALHO, F.T., GALO, M.L.B.T., VELINI, E.D. \& MARTINS, D. 2003. Plantas aquáticas e nível de infestação das espécies presentes no reservatório de Barra Bonita, no rio Tietê. Planta Daninha 21: 15-19. 
CARVALHO, F.T., VELINI, E.D. \& MARTINS, D. 2005. Plantas aquáticas e nível de infestação das espécies presentes no reservatório de Bariri, no Rio Tietê. Planta Daninha 23: 371-374.

CAVALCANTI, T.B. \& GRAHAM., S. 2007. Lythraceae. In M.G.L. Wanderley, G.J. Shepherd, A.M. Giulietti, T.S. Melhem, V. Bittrich \& C. Kameyama (eds.). Flora fanerogâmica do Estado de São Paulo. HUCITEC, FAPESP. São Paulo, v. 2, p. 163-180.

CAVALCANTI, T.B. \& GRAHAM, S. 2016. Cuphea In Lista de Espécies da Flora do Brasil. Jardim Botânico do Rio de Janeiro. Disponível em: <http://floradobrasil.jbrj.gov.br/jabot/ floradobrasil/FB8744>. Acesso em: 18 Jan. 2016

CAVENAGHI, A.L., VELINI, E.D., GALO, M.L.B.T., CARVALHO, F.T., NEGRISOLI, E., TRINDADE, M.L.B. \& SIMIONATO, J.L.A. 2003. Caracterização da qualidade de água e sedimento relacionados com a ocorrência de plantas aquáticas em cinco reservatórios da bacia do rio Tietê. Planta Daninha 21: 43-52.

CAVENAGHI, A.L., VELINI, E.D., NEGRISOLI, E., CARVALHO, F.T., GALO, M.L.B.T., TRINDADE, M.L.B. \& SANTOS, S.C.A. 2005. Monitoramento de problemas com plantas aquáticas e caracterização da qualidade de água e sedimento na UHE MogiGuaçu. Planta Daninha 23: 225-231.

CETESB. 1996. Avaliação do Complexo Billings: comunidades aquáticas - (Out./92 a Out./93). DAH. CETESB. São Paulo.

CHUKR, N.S. \& CAPELLARI JR., L. 2003. Iridaceae. In M.G.L. Wanderley, G.J. Shepherd, T.S. Melhem, A.M. Giulietti \& M. Kirizawa (eds.) Flora fanerogâmica do Estado de São Paulo. RiMa, FAPESP. São Paulo, vol.3, p. 127-147.

COELHO, M.A.N., SOARES, M.L., CALAZANS, L.S.B., GONÇALVES, E.G., ANDRADE, I.M., PONTES, T.A., SAKURAGUI, C.M., TEMPONI, L.G., BUTURI, C. \& MAYO, S.J. 2016. Araceae In Lista de Espécies da Flora do Brasil. Jardim Botânico do Rio de Janeiro. Disponível em: <http://floradobrasil.jbrj.gov.br/jabot/floradobrasil/ FB5004>. Acesso em: 18 Jan. 2016.

COOK, C.D.K. 1996. Aquatic plant book. The Hague. SPB Academic Publishing.

COOK, C.D.K. 1999. The number and kinds of embryo-bearing plants which have become aquatic: a survey. Perspec. Pl. Ecol. Evol. Syst. 2(1): 79-102.
COOK, C.D.K., GUT, B.J., RIX, E.M., SCHNELLER, J. \& BEITZ, M. 1974. Walter plants of the world: a manual for the identification of the genera of freshwater macrophytes. Dr. W. Junk. The Hague.

CORRÊA, I.P. \& PIRANI, J.R. 2005. Apiaceae. In M.G.L. Wanderley, G.J. Shepherd, T.S. Melhem, S.E. Martins, M. Kirizawa \& A.M. Giulietti (eds.) Flora fanerogâmica do Estado de São Paulo. RiMa, FAPESP. São Paulo, vol. 4, p.11-34.

CORREA, M.A. \& MAMEDE, M.C.H. 2002. Lentibulariaceae. In M.G.L. Wanderley, G.J. Shepherd, A.M. Giulietti, T.S. Melhem, V. Bittrich \& C. Kameyama (eds.). Flora fanerogâmica do Estado de São Paulo. HUCITEC, FAPESP. São Paulo, vol. 2, p. 141-154.

CRANDALL-STOTLER, B. \& STOTLER, R.E. 2000. Morphology and classification of the Marchantiophyta. In A. Shaw \& B. Goffinet (eds.) Bryophyte biology. Cambridge University. Cambridge, p. 21-70.

DELELLO, D. 2008. Composição e distribuição (espacial e temporal) de macrófitas aquáticas no reservatório do Lobo - (Broa) - Itirapia - Brotas $S P$. Dissertação de Mestrado. Escola de Engenharia de São Carlos, Universidade de São Paulo, São Carlos.

EGGERS, L. 2015. Sisyrinchium in Lista de Espécies da Flora do Brasil. Jardim Botânico do Rio de Janeiro. Disponivel em: <http://floradobrasil.jbrj. gov.br/jabot/floradobrasil/FB8071>.

FARIA, A.D.D. 1998. O gênero Eleocharis R.Br. (Cyperaceae) no estado de São Paulo. Dissertação de Mestrado. Instituto de Biologia, Universidade Estadual de Campinas. Campinas.

FARIA, A.D.D. \& AMARAL, M.C.E. 2005. Pontederiaceae. In M.G.L. Wanderley, G.J. Shepherd, T.S. Melhem, S.E. Martins, M. Kirizawa \& A.M. Giullietti (eds.). Flora fanerogâmica do Estado de São Paulo. FAPESP/RiMa. São Paulo, vol. 4, p. 325-330.

FERES, F. \& AMARAL, M.C.E. 2003. Nymphaeaceae. In M.G.L. Wanderley, G.J. Shepherd, T.S. Melhem, A.M. Giullietti \& M. Kirizawa (eds.) Flora fanerogâmica do Estado de São Paulo. FAPESP, RiMa. São Paulo, vol.3, p. 241-245.

FIDALGO, O. \& BONONI, V.R.L. 1989. Técnicas de coleta, preservação e herborização de material botânico. Instituto de Botânica. São Paulo. 
Levantamento de plantas aquáticas e palustres na represa Guarapiranga, São Paulo

FILGUEIRAS, T.S., LONGHI-WAGNER, H.M., VIANA, P.L., ZANIN, A., GUGLIERI, A., OLIVEIRA, R.C.D. \& OLIVEIRA, R.P. 2016. Poaceae In Lista de Espécies da Flora do Brasil. Disponível em: <http://floradobrasil.jbrj.gov.br/jabot/floradobrasil/ FB193>. Acesso em: 18 Jan. 2016.

FONT QUER, P. 1989. Diccionario de Botánica. Editorial Labor. Barcelona.

FORNO, I.W. 1983. Native distribution of the SalviniaAuriculata complex and keys to species identification. Aquat. Bot. 17(1): 71-83.

FRANÇA, F., MELO, E., ARISTÓTELES, G.N., ARAÚJO, D., BEZERRA, M. G., RAMOS, H.M. \& GOMES, D. 2003. Flora vascular de açudes de uma região do semi-árido da Bahia, Brasil. Acta bot. bras. 17(4): 549-559.

FREITAS, M.F. \& CARRIJO, T.T. 2016. Primulaceae In Lista de Espécies da Flora do Brasil. Jardim Botânico do Rio de Janeiro. Disponível em: $<$ http://floradobrasil.jbrj.gov.br/jabot/floradobrasil/F B123044>. Acesso em: 18 Jan. 2016.

GARCIA, R.J.F. \& IZUMIZAWA, C.M. 2003. Primulaceae In M.G.L. Wanderley, G.J. Shepherd, T.S. Melhem, A.M. Giulietti \& M. Kirizawa (eds.) Flora fanerogâmica do Estado de São Paulo. FAPESP, RiMa. São Paulo, vol. 3, p. 275-278.

GIULIETTI, A.M., SANO, P.T., COSTA, F.N., PARRA, L. R., ECHTERNACHT, L., TISSOT-SQUALI, M.L. \& HENSOLD, N. 2015. Eriocaulaceae In Lista de Espécies da Flora do Brasil. Jardim Botânico do Rio de Janeiro. Disponível em: < (http://floradobrasil.jbrj.gov.br/2015/FB035540) > .

GOETGHEBEUR, P. 1998. Cyperaceae. In K. Kubitzki (ed.) The families and genera of vascular plants. Springer. Berlin, p. 141-190.

GUIMARÃES, P.J.F. 2009. Acisanthera. Tibouchina. In S.E. Martins, M.G.L. Wanderley, G.J. Shepherd, A.M. Giulietti \& T.S. Melhem (eds.) Flora fanerogâmica do Estado de São Paulo. Instituto de Botânica, FAPESP. São Paulo, vol. 6, p. 5-7, 127149.

HAYNES, R. R. 1984. Techniques for collecting aquatic and marsh plants. Ann. Missouri Bot. Gard. 71: 229-231.

HELOU, L.C. \& SILVA, L.G. 1987. Estudo de operação do reservatório Guarapiranga. Rev. DAE, SABESP, 48(151): 29-47.
HENRY-SILVA, G.G., MOURA, R.S.T.D. \& DANTAS, L.L.D.O. 2010. Richness and distribution of aquatic macrophytes in Brazilian semi-arid aquatic ecosystems. Acta limnol. brasil. 22(2): 147-156.

HOEHNE, F.C. \& MUNZ, P.A. 1947. Flora brasilica: Onagraceas. Instituto de Botânica. São Paulo, vol. 1.

ILTIS, H.H. \& COCHRANE, T.S. 2007. Studies in the Cleomaceae $\mathrm{V}$ : a new genus and ten new combinations for the Flora of North America. Novon 17(4): 447-421.

IRGANG, B.E. \& GASTAL JR., C.V.D.S. 1996. Macrófitas aquáticas da planície costeira do RS. Edição dos autores. Porto Alegre.

IRGANG, B.E. \& GASTAL JR., C.V.D.S. 2003. Problemas taxonômicos e distribuição geográfica de macrófitas aquáticas do sul do Brasil. In S.M. THOMAZ \& L.M. BINI (eds.) Ecologia e manejo de macrófitas aquáticas. EDUEM. Maringá, p. 341.

IRGANG, B.E., PEDRALLI, G. \& WAECHTER, J.I. 1984. Macrófitas aquáticas da Estação Ecológica do Taim. Roessleria 6: 395-404.

JACQUES, E.D.L. 2002. Estudos taxonômicos das espécies brasileiras do gênero Begonia $L$. (Begoniaceae) com placenta partida. Tese de Doutorado, Instituto de Biociências, Universidade de São Paulo. São Paulo.

JOHNSTON, I.M. 1938. The species of Sisyrinchium in Uruguay, Paraguay and Brazil. J. Arnold Arb.19: 376-401.

JUNG-MENDAÇOLLI, S.L. (coord.) 2007. Rubiaceae. In T.S. Melhem, M.G.L. Wanderley, S.E. Martins, S.L. Jung-Mendaçolli, G.J. Shepherd \& M. Kirizawa (eds.) Flora fanerogâmica do Estado de São Paulo. Instituto de Botanica, FAPESP. São Paulo, vol. 5, p. 259-460.

KISSMANN, K.G. \& GROTH, D. 2000. Plantas infestantes e nocivas. BASF. São Paulo, 3 vols.

KRAL, R. 1971. A treatment of Abildgaardia, Bulbostylis and Fimbristylis for North America. SIDA 4(2): 57-227.

KRIEBEL, R. \& ROCHA, M.J.R. 2016. Acisanthera In Lista de Espécies da Flora do Brasil. Jardim Botânico do Rio de Janeiro. Disponível em: $<$ http://floradobrasil.jbri.gov.br/jabot/floradobrasil/F B19606>. Acesso em: 18 Jan. 2016. 
LOLIS. S.D.F. 2008. Macrófitas aquáticas do reservatório Luís Eduardo Magalhães - Lajeado Tocantins: biomassa, composição da comunidade e riqueza de espécies. Tese de Doutorado, Universidade Estadual de Maringá. Maringá.

LONGHI-WAGNER, H.M. (coord.) 2001. Poaceae. In H.M. Longhi-Wagner, V. Bittrich, M.G.L. Wanderley \& G.J. Shepherd (eds.) Flora fanerogâmica do Estado de São Paulo. FAPESP, HUCITEC. São Paulo, vol. 1, p. 1-291.

LORENZI, H. 2000. Plantas daninhas do Brasil: terrestres, aquáticas, parasitas, tóxicas e medicinais. Ed. 2. Instituto Plantarum. Nova Odessa.

LUCENO, M. \& ALVES, M.V. 1997. Clave de los géneros de Ciperáceas de Brasil y novedades taxonómicas y corológicas en la família. Candollea 52(1): 185-197.

LUZ, C. L. Taxonomia da família Juncaceae no Rio Grande do Sul, Brasil. 2004. Dissertação de Mestrado. Universidade Federal do Rio Grande do Sul. Porto Alegre.

MARTINS, D., COSTA, N.V., TERRA, M.A. \& MARCHI, S.R. 2008. Caracterização da comunidade de plantas aquáticas de dezoito reservatórios pertencentes a cinco bacias hidrográficas do Estado de São Paulo. Planta Daninha 26: 17-32.

MARTINS, D., PITELLI, R.A., TOMAZELLA, M.S., TANAKA, R.H. \& RODRIGUES, A.C.P. 2009. Levantamento da infestação de plantas aquáticas em Porto Primavera antes do enchimento final do reservatório. Planta Daninha 27: 879-886.

MARTINS, D., VELINI, E.D., PITELI, R.A., TOMAZELLA, M.S. \& NEGRISOLI, E. 2003. Ocorrência de plantas aquáticas nos reservatórios da Light-RJ. Planta Daninha 21: 105-108.

MATIAS, L.Q., AMADO, E.R. \& NUNES, E.P. 2003. Macrófitas aquáticas da lagoa de Jijoca de Jericoacoara, Ceará, Brasil. Acta bot. bras.17: 623631.

MATIAS, L.Q., LOPES, R.C. \& SAKURAGUI, C.M. 2016. Alismataceae In Lista de Espécies da Flora do Brasil. Jardim Botânico do Rio de Janeiro. Disponível em: <http://floradobrasil.jbri.gov.br/jabot/ floradobrasil/FB21743>. Acesso em: 18 Jan. 2016.
MELO, E. 2016. Polygonaceae In Lista de Espécies da Flora do Brasil. Jardim Botânico do Rio de Janeiro. Disponivel em: <http://floradobrasil.jbri.gov.br/jabot/ floradobrasil/FB13722>. Acesso em: 18 Jan. 2016.

MELO, E. \& MARCONDES-FERREIRA, W. 2009. Polygonaceae. In S.E, Martins, M.G.L. Wanderley, G.J. Shepherd, A.M. Giulietti \& T.S. Melhem (eds.) Flora fanerogâmica do Estado de São Paulo. Instituto de Botanica, FAPESP. São Paulo, vol. 6, p. 169-193.

MELO, J.I.M. \& SEMIR, J. 2008. Taxonomia do gênero Heliotropium L. (Heliotropiaceae) no Brasil. Acta bot. bras. 2(3): 754-770.

MELO, J.I.M \& SEMIR, J. 2009. Two new Brazilian species and new combinations in Euploca (Heliotropiaceae). Kew Bull. 64(2): 285-289.

MOREIRA, J.L.D.A. 1997. Estudo taxonômico da subtribo Phaseolinae no Sudeste e Centro-Oeste do Brasil. Dissertação de Mestrado. Instituto de Biologia, Universidade Estadual de Campinas. Campinas.

MORRONE, O. \& ZULOAGA, F.O. 1992. Revisión de las especies sudamericanas nativas e introducidas de los géneros Brachiaria y Urochloa (Poaceae: Panicoideae: Paniceae). Darwiniana 31(1-4): 43109.

MOZETO, A.A., SILVERIO, P.F. \& SOARES, A. 2001. Estimates of benthic fluxes of nutrients across the sediment-water interface (Guarapiranga reservoir, São Paulo, Brazil). Sci. Total Environ. 266(1-3): 135-142.

NAKAJIMA, J.N., LOEUILLE, B., HEIDEN, G., DEMATTEIS, M., HATTORI, E.K.O., MAGENTA, M., RITTER, M. \& MORAES, M.D. 2016. Asteraceae In Lista de Espécies da Flora do Brasil. Jardim Botânico do Rio de Janeiro. Disponível em (http://floradobrasil.jbrj.gov.br/2015/FB55).

PANSARIN, E.R. \& AMARAL, M.C.E. 2005. Alismataceae. In M.G.L. Wanderley, G.J. Shepherd, T.S. Melhem, S.E. Martins, M. Kirizawa \& A.M. Gulietti (eds.). Flora fanerogâmica do Estado de São Paulo. RiMa, FAPESP. São Paulo, vol. 4, p. 1-10.

PEDRALLI, G. 1990. Macrófitas aquáticas. Técnicas e métodos de estudos. Est. Biol. 26: 5-24.

PEDRALLI, G., MEYER, S.T., TEIXEIRA, M.C. \& STEHMANN, J.R. 1993a. Levantamento das macrófitas aquáticas e da mata ciliar do reservatório de Volta Grande, Minas Gerais, Brasil. Iheringia, sér. Botânica 43: 29-40. 
Levantamento de plantas aquáticas e palustres na represa Guarapiranga, São Paulo

PEDRALLI, G., STEHMANN, J.R., TEIXEIRA, M.C., OLIVEIRA, V.L. \& MEYER, S.T. 1993b. Levantamento da vegetação aquática ("macrófitos") na área da EPDA-Peti, Santa Bárbara, MG. Iheringia, sér. Botânica, 43: 15-28.

POMPÊO, M.L.M. 2008. Monitoramento e manejo de macrófitas aquáticas. Oecologia Brasiliensis 12(3): 406-424.

POMPÊO, M.L.M., RODRIGUES, M.E.F., HIRATA, R.T. \& MACEDO, C.C.L.D. 2008. As macrófitas aquáticas: tipos ecológicos, importância para 0 ecossistema, monitoramento e controle do crescimento. In L.R.B. Malagoli \& M. Whately (eds.) Além do concreto: contribuições para a proteção da biodiversidade paulistana. Instituto Socioambiental. São Paulo, p. 92-111.

POMPÊO, M.L.M., RODRIGUES, M.E.F., HIRATA, R.T., MACEDO, C.C.L.D. \& MOSCHINI-CARLOS, V. 2011a. Banco de dados de macrófitas aquáticas. Disponível em: <http://ecologia.ib. usp.br/macrofita $>$.

POMPÊO, M.L.M., RODRIGUES, M.E.F., HIRATA, R.T., MACEDO, C.C.L.D. \& MOSCHINI-CARLOS, V. 2011b. CD-Room de macrófitas aquáticas. São Paulo, ISSN 978-8591177004.

POTT, V.J. 2002. Lemnaceae. In M.G.L. Wanderley, G.J. Shepherd, A.M. Giulietti, T.S. Melhem, V. Bittrich \& C. Kameyama (eds.). Flora fanerogâmica do Estado de São Paulo. HUCITEC, FAPESP. São Paulo, vol. 2, p. 135-140.

POTT, V.J., BUENO, N.C., PEREIRA, R.A.C., SALIS, S.M. \& VIEIRA, N.L. 1989. Distribuição de macrófitas aquáticas numa lagoa na fazenda Nhumirim, Nhecolândia, Pantanal, MS. Acta bot. bras. 3(2): 168-253.

POTT, V.J. \& POTT, A. 2000. Plantas aquáticas do Pantanal. Embrapa Comunicação para Transferência de Tecnologia. Brasília.

RADFORD, A.E., DICKISON, W.C., MASSEY, J.R. \& BELL, C.R. 1974. Vascular plant systematics. Harper \& Row. New York.

SAKAGAMI, C.R. 2006. Pteridófitas do Parque Ecológico da Klabin, Telemâco Borba, Paraná, Brasil. Dissertação de Mestrado. Universidade Federal do Paraná. Curitiba.

SALINO, A. \& ALMEIDA, T.E. 2016. Salviniaceae In Lista de Espécies da Flora do Brasil. Jardim Botânico do Rio de Janeiro. Disponível em: <http://floradobrasil.jbrj.gov.br/jabot/floradobrasil/ FB115594>. Acesso em: 18 Jan. 2016.
SCALON, V.R. \& SOUZA, V.C. 2002. Brassicaceae. In M.G.L. Wanderley, G.J. Shepherd, A.M. Giulietti, T.S. Melhem, V. Bittrich \& C. Kameyama (eds.) Flora fanerogâmica do Estado de São Paulo. HUCITEC, FAPESP. São Paulo, vol. 2, p. 57-63.

SCREMIN-DIAS, E., POTT, V.J., HORA, R.C.D., SOUZA, P.R.D., BOGGIANI, P.C. \& FROEHLICH, O. 1999. Nos jardins submersos da Bodoquena: guia para identificação de plantas aquáticas de Bonito e região. Editora da Universidade Federal do Mato Grosso do Sul. Campo Grande.

SIMÃO-BIANCHINI, R. 1998. Ipomoea L. (Convolvulaceae) no sudeste do Brasil. Tese de Doutorado. Instituto de Biociências, Universidade de São Paulo. São Paulo.

SIQUEIRA, J.C. 2002. Amaranthaceae. In M.G.L. Wanderley, G.J. Shepherd, A.M. Giulietti, T.S. Melhem, V. Bittrich \& C. Kameyama (eds.) Flora fanerogâmica do Estado de São Paulo. HUCITEC, FAPESP. São Paulo, vol. 2, p. 11-30.

SLUSARSKI, S.R., CERVI, A.C. \& GUIMARÃES, O.A. 2007. Estudo taxonômico das espécies nativas de Hypericum L. (Hypericaceae) no Estado do Paraná, Brasil. Acta bot. bras. 21(1): 163-184.

SMA. 2004. Resolução SMA-48. DOE 114 (179): 2629. Disponível em: <https://www.imprensaoficial. com.br/DO/>. Acesso em: 03 maio 2010.

SMITH, A.L., PRYER, K.M., SCHUETTPELZ, E., KORALL, P.S.H. \& WOLF, P.G. 2006. A classification for extant ferns. Taxon 55(3): 705731.

SOUZA, V.C. 1996. Levantamento das espécies de Scrophulariaceae nativas do Brasil. Tese de Doutorado. Instituro de Biociências, Universidade de São Paulo. São Paulo.

SOUZA, V.C. 2003. Scrophulariaceae. In M.G.L. Wanderley, G.J. Shepherd, T.S. Melhem, A.M. Giulietti \& M. Kirizawa (eds.) Flora fanerogâmica do Estado de São Paulo. RiMa, FAPESP. São Paulo, vol. 3, p. 297-321.

SOUZA, V.C. \& LORENZI, H. 2005. Botânica sistemática: Guia ilustrado para identificação das famílias de Angiospermas da flora brasileira, baseado em APG II. Instituto Plantarum de Estudos da Flora. Nova Odessa.

STAFLEU, F.A. \& COWAN, R.S. 1976. Taxonomic literature: $A$ selective guide to botanical publications and collections with dates, commentaries and types. Ed. 2. Bohn, Scheltema \& Holkema. Utrecht. 
STEARN, W.T. 1983. Botanical latin: history, grammar, syntax, terminology, and vocabulary. Ed. 3. David \& Charles. Newton Abbot.

TANAKA, R.H., CARDOSO, L.R., MARTINS, D., MARCONDES, D.A.S. \& MUSTAFÁ, A.L. 2002. Ocorrência de plantas aquáticas nos reservatórios da Companhia Energética de São Paulo. Planta Daninha 20: 101-111.

TAVARES, K.S. 2003. A comunidade de macrófitas aquáticas em reservatórios do médio e baixo Rio Tietê (SP) e lagos da bacia do médio Rio Doce (MG). Dissertação de Mestrado. Universidade Federal de São Carlos. São Carlos.

THOMAZ, S.M. \& BINI, L.M. 1999. A expansão das macrófitas aquáticas e implicações para manejo de reservatórios: um estudo na represa de Itaipu. In R. Henry (ed.) Ecologia de reservatórios: Estrutura, função e aspectos sociais. FUNDIBIO, FAPESP. Botucatu, p. 597-626.

THOMAZ, S.M. \& BINI, L.M. 2003. Análise crítica dos estudos sobre macrófitas aquáticas desenvolvidos no Brasil. In S.M. Thomaz \& L.M. Bini (eds.) Ecologia e manejo de macrófitas aquáticas. EDUEM. Maringá, p. 19-35.

THOMAZ, S.M., BINI, L.M. \& PAGIORO, T.A. 2003. Macrófitas aquáticas em Itaipu: ecologia e perspectivas para o manejo. In S.M. Thomaz \& L.M. Bini (ed.). Ecologia e manejo de macrófitas aquáticas. EDUEM. Maringá, p. 341.

TRYON, R.M. \& TRYON, A.F. 1982. Ferns and allied plants with special reference to tropical America. Springer. New York.

TIPPERY, N.P. \& LES, D.H. 2011. Phylogenetic relationships and morphological evolution in Nymphoides (Menyanthaceae). Syst. Bot. 36(4): 1101-1113.

VIANA, S.M. 2005. Riqueza e distribuição de macrófitas aquáticas no Rio Monjolinho e tributários (São Carlos, SP) e análise de sua relação com variáveis físicas e químicas. Dissertação de Mestrado. Universidade de São Paulo. São Carlos.

VIEIRA, A.O.S. 2003. Campanulaceae. In M.G.L. Wanderley, G.J. Shepherd, T.S. Melhem, A.M. Giulietti \& M. Kirizawa (eds.) Flora fanerogâmica do Estado de São Paulo. RiMa, FAPESP. São Paulo, vol. 3, p. 13-32.
VIEIRA, A.O.S. 2015. Onagraceae. In Lista de espécies da Flora do Brasil. Jardim Botânico do Rio de Janeiro. Disponível em: <http://floradobrasil.jbrj.gov.br/jabot/floradobrasil/ FB4035>. Acesso em: 18 Mai. 2015.

ZULOAGA, F., MORRONE, O., BELGRANO, M., MARTICORENA, C. \& MARCHESI, E. (eds.) 2008. Catálogo de las Plantas Vasculares del Cono Sur (Argentina, Sur de Brasil, Chile, Paraguay y Uruguay). Monogr. Syst. Bot. Missouri Bot. Gard. 107(1): 1-983; 107(2): 985-2286; 107(3): 22873348.

WANDERLEY, M.G.L. 2003. Xyridaceae. In M.G.L. Wanderley, G.J. Shepherd, T.S. Melhem, A.M. Giulietti \& M. Kirizawa (eds.) Flora fanerogâmica do Estado de São Paulo. RiMa, FAPESP. São Paulo, vol. 3, p. 333-348.

WANDERLEY, M.G.L., SHEPHERD, G.J. \& GIULLIETTI, A.M. (coord.) 2002. Flora fanerogâmica do Estado de São Paulo. HUCITEC, FAPESP. São Paulo, vol. 2.

WANDERLEY, M.G.L., SHEPHERD, G.J., A.M. GIULIETTI \& MELHEM, T.S. (eds.) 2003. Flora fanerogâmica do Estado de São Paulo. RiMa, FAPESP. São Paulo, vol. 3.

WANDERLEY, M.G.L., SHEPHERD, G.J., MELHEM, T.S. \& GIULIETTI, A.M. (eds.) 2005. Flora fanerogâmica do Estado de São Paulo. RiMa, FAPESP. São Paulo, vol. 4.

WANDERLEY, M.G.L., SHEPHERD, G.J., MELHEM, T.S. \& GIULIETTI, A.M. (eds.) 2007. Flora fanerogâmica do Estado de São Paulo. Instituto de Botânica, FAPESP. São Paulo, vol. 5.

WANDERLEY, M.G.L., SHEPHERD, G.J., MELHEM, T.S., GIULIETTI, A.M. \& MARTINS, S.E. (eds.) 2009. Flora fanerogâmica do Estado de São Paulo. Instituto de Botânica, FAPESP. São Paulo, vol. 6.

WATSON, L. \& DALLWITZ, M.J. 1992. Ther grass genera of the world. C.A.B. Internacional. Wallingford.

WETZEL, R.G. \& LIKENS, G.E. 2000. Limnological analyses. Ed. 3. Springer. New York. 